\title{
Effect of Aging on Aluminum Hydroxide Complexes in Dilute Aqueous Solutions
}

GEOLOGICAL SURVEY WATER-SUPPLY PAPER 1827-D

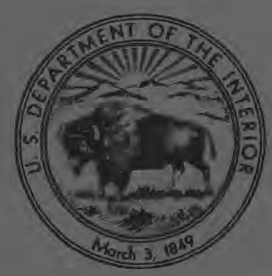




\section{Effect of Aging on Alumin $\ulcorner$ m Hydroxide Complexes in Dilute Aqueous Solutions}

By R. W. SMITH and J. D. HEM

CHEMISTRY OF ALUMINUM IN NATURAL WATER

GEOLOGICAL SURVEY WATER-SUPPLY PAPER 1827-D

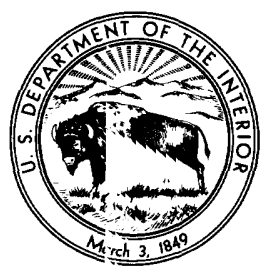

UNITED STATES GOVERNMENT PRINTING OFFICE, WASHING $:$ ON $: 1972$ 


\section{UNITED STATES DEPARTMENT OF THE INTERIOP}

ROGERS C. B. MORTON, Secretary

\section{GEOLOGICAL SURVEY}

V. E. McKelvey, Director

Library of Congress catalog-card No. 79-189478

For sale by the Superintendent of Documents, U.S. Government Printir Washington, D.C. 20402 - Price 40 cents (paper cover) 


\section{CONTENTS}

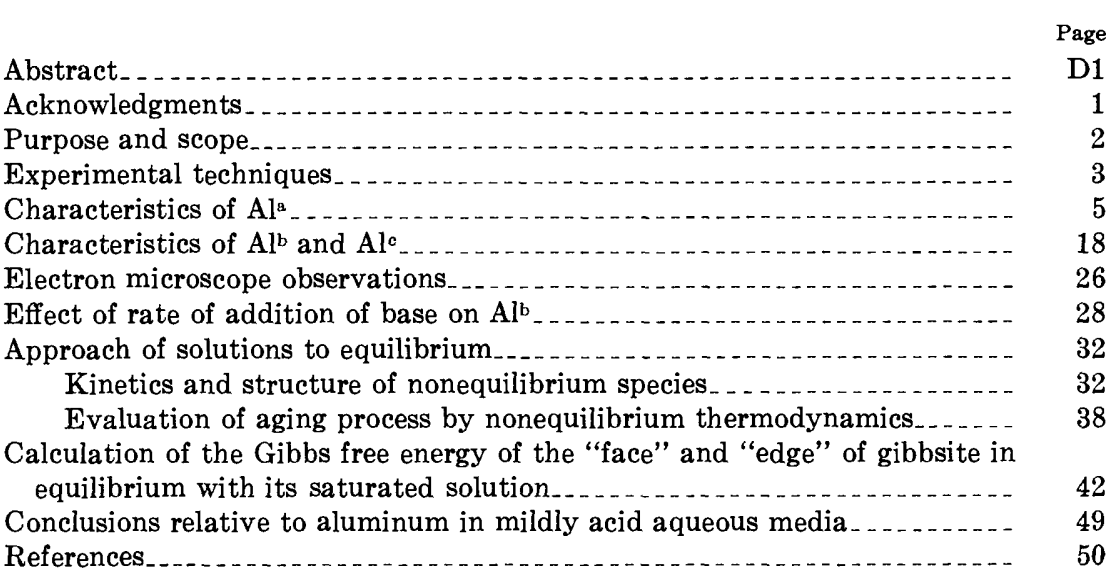

\section{ILLUSTRATIONS}

FIGURES 1-3. Graphs showing concentration of-

1. $\mathrm{Al}{ }^{\mathrm{a}}$ as a function of $r_{n}$ value ..............

2. $\mathrm{Al}^{\mathrm{a}}$ as a function of $\mathrm{pH}$ for solutions $\mathrm{B}-\mathrm{H}$ at various aging times.

3. $\mathrm{Al}^{\mathrm{a}+\mathrm{b}}$ as a function of $\mathrm{pH}$ at various aging times...

4-11. Graphs showing aging time effect on activity of monomeric species as a function of $\mathrm{pH}$ for-

4. Solution $\mathrm{B}$

5. Solution C

6. Solution D

7. Solution E.

8. Solution F $\ldots \ldots$

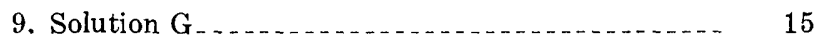

10. Solution $\mathrm{H}_{\ldots} \ldots \ldots \ldots$

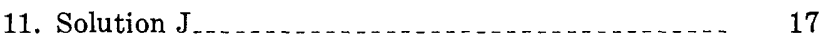

12-18. Concentration of $\mathrm{Al}^{\mathrm{b}}$ and $\mathrm{Al}^{\mathrm{c}}$ as a function of $\mathrm{pH}$ and aging time for-

12. Solution B . .

13. Solution C

14. Solution D $\ldots \ldots \ldots \ldots$

15. Solution E.... 22 
Figures 12-18. Concentration of $\mathrm{Al}^{\mathrm{b}}$ and $\mathrm{Al}^{\mathrm{c}}$ as a function of $\mathrm{pH}$ and aging time for-Continued

16. Solution $\mathrm{F}$

D23

17. Solution $\mathrm{G}$

18. Solution $\mathrm{H}$

19-22. Electron micrograph of microcrystalline gibbsite f־om-

19. Solution $\mathrm{F}$ aged 2 years

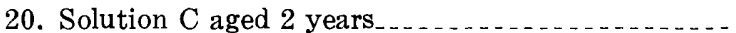

21. Solution E aged 2 years $\ldots \ldots \ldots$

22. Solution $J_{2}$ aged about 2 months . . . . . . . . . . . .

23-25. Graphs showing-

23. Effect of length of time of adding base in p"eparing solutions on amount of $\mathrm{Al}^{\mathrm{b}}$ formed . . . . . . . . .

24. First-order rate plot of $\mathrm{Al}^{\mathrm{b}}$ data from figur’ $23 \ldots$

25. Number of aluminum atoms as a function of the $\mathrm{OH}: \mathrm{Al}^{\mathrm{b}}$ ratio of the $\mathrm{Al}^{\mathrm{b}}$ particle.

26. Schematic representation of the ring structure formed by six aluminum hydroxide octahedra.

27. Sketch showing growth of polynuclear aluminum hydroxide

28-31. Graphs showing-

28. Concentration of $\mathrm{Al}^{\mathrm{b}}$ residual as a function of aging time for solutions $\mathrm{D}, \mathrm{E}, \mathrm{F}, \mathrm{G}$, and $\mathrm{H}$

29. Advancement of the reaction $\left(\xi_{\mathrm{Al}} \mathrm{b}\right)$ as a function of aging time for solutions $\mathrm{D}, \mathrm{E}, \mathrm{F}, \mathrm{G}$, and $\mathrm{H} \ldots$

30. Reaction affinity as a function of reaction velocity $\left(d \xi_{\mathrm{Al}}^{\mathrm{b}} / d t\right)$

31. Relationship between the $D$ dimension of the $\mathrm{Al}^{\mathrm{b}}$ particles and the $\mathrm{OH}: \mathrm{Al}^{\mathrm{b}}$ ratio of these particles. .

\section{TABLES}

TABLE 1. Concentrations of various types of aluminum in relation to age

2. Concentrations of monomeric aluminum $\left(\mathrm{Al}^{\mathrm{a}}\right)$

3. Gibbs free energies of formation of monomeric aluminum snecies . -

4. Activity coefficients of monomeric species for $\sim 10^{-2}$ ionic strength solutions

5. Reaction affinities of solutions in relation to age

6. Advancement of the reaction $\left(\xi_{\mathrm{A}} \mathrm{b}\right)$ values and $\mathrm{A} \mathrm{l}^{\mathrm{b}}$ residual values of solutions in relation to age

7. Estimated order of aging reaction relative to $\mathrm{Al}^{\mathrm{b}}$

8. $\mathrm{OH}: \mathrm{Al}^{\mathrm{b}}$ ratios for $\mathrm{Al}^{\mathrm{b}}$ particles and corresponding reaction affinities

9. Calculated $\gamma \mathrm{E}$ and $\gamma \mathrm{F}$ values 


\title{
CHEMISTRY OF ALUMINUM IN NATURAL WATER
}

\section{EFFECT OF AGING ON ALUMINUM HYDROXIDE COMPLEXES IN DILUTE AQUEOUS SOLUTIONS}

\author{
By R. W. Smith and J. D. Hem
}

\section{ABSTRACT}

Aqueous aluminum solutions containing $4 \times 10^{-5}$ mole/liter aluminum and a constant total ionic strength of $10^{-2}$, but with varying ratios of hydroxide to aluminum $(\mathrm{OH}: \mathrm{Al})$, were prepared. Progress of these solutions toward equilibrium conditions over aging periods of as much as 2 years was studied by determining the composition and $\mathrm{pH}$ of the solutions at various time intervals. The solution?, after mixing, were supersaturated with respect to both crystalline and amorphous forms of aluminum oxides and aluminum hydroxides. The compositions of the sclutions were determined by use of a timed colorimetric analytical procedure which allowed the estimation of three separate forms of aluminum that have been designated $\mathrm{Al}^{\mathrm{a}}$, $\mathrm{Al}^{\mathrm{b}}$, and $\mathrm{Al}^{\mathrm{c}}$. Form $\mathrm{Al}^{\mathrm{a}}$ appeared to be composed of monomeric species such as $\mathrm{Al}\left(\mathrm{H}_{2} \mathrm{O}\right)_{6}{ }^{+3}, \mathrm{Al}(\mathrm{OH})\left(\mathrm{H}_{2} \mathrm{O}\right)_{5}{ }^{+2}, \mathrm{Al}(\mathrm{OH})_{2}\left(\mathrm{H}_{2} \mathrm{O}\right)_{4}{ }^{+1}$ and $\mathrm{Al}(\mathrm{OH})_{4}{ }^{-}$. Form $\mathrm{Al}^{\mathrm{b}}$ was polynuclear material containing perhaps $20-400$ aluminum atoms per structure. It appeared to be a metastable material. Form $\mathrm{Al}^{\mathrm{c}}$ was composed of relatively large, microcrystalline, clearly solid $\mathrm{Al}(\mathrm{OH})_{3}$ particles.

For each $\mathrm{OH}: \mathrm{Al}$ ratio, the concentration of $\mathrm{Al}^{\mathrm{a}}$ remained constant with agir time, $\mathrm{Al}^{\mathrm{b}}$ decreased, and $\mathrm{Al}^{\mathrm{l}}$ increased. It appeared that $\mathrm{Al}^{\mathrm{b}}$ particles were increasing in size and ultimately were converted to $\mathrm{Al}^{\circ}$ particles. After a few weeks' ag'ng, $\mathrm{Al}^{\circ}$ particles had the structure of gibbsite.

In all solutions, equilibrium was only very slowly achieved, and the time required depended on the $\mathrm{OH}: \mathrm{Al}$ ratio and how rapidly the solution was initially prepared (mixing time). Lower ratios caused a slower approach to equilibrium; sometimes equilibrium was not achieved even after several years' aging. The more slowly base was initially added (to obtain the proper $\mathrm{OH}: \mathrm{Al}$ ratio), the more slowly was equilibrium approached. Ultimate equilibrium values of dissolved aluminum concentration and $\mathrm{pH}$ were consistent with known thermodynamic data on monomeric aluminum species.

From data determined during the aging study and by considering $\mathrm{Al}^{\mathrm{b}}$ material to consist of extremely small solid gibbsite particles, it was possible to estimate the Gibbs free energy of the (001) crystal face ( $\gamma_{F}$, the gibbsite "face") and the Gibbs free energy of the (110) and (100) crystal faces ( $\gamma E$, the gibbsite "edge") of gibbsite in equilibrium with its saturated solution. These values were:

$$
\begin{aligned}
& \gamma_{F}=140 \pm 24 \mathrm{ergs} / \mathrm{cm}^{2}, \text { and } \\
& \gamma_{E}=483 \pm 84 \mathrm{rgs} / \mathrm{cm}^{2} .
\end{aligned}
$$

\section{ACKNOWLEDGMENTS}

Much of the material used in this paper was taken from a disertation submitted by $R$. W. Smith in partial fulfillment of the requirements for the Ph. D. degree, Stanford University. 
The help of and many discussions with Prof. G. A. Parks of Stanford University are gratefully acknowledged.

\section{PURPOSE AND SCOPE}

The experiments described in chapter A of this water-supply paper (Hem and Roberson, 1967) were concerned with dilute aqueous solutions of aluminum in the presence of perchlorate, hydrcxide, hydrogen, and sodium ions. When these solutions were partly neutralized by addition of sodium hydroxide so that the molar ratio $(r)$ of combined hydroxide to total aluminum $(\mathrm{OH}: \mathrm{Al})$ was between 1.0 and 3.0 , the solutions contained both monomeric and polymeric forms of aluminum hydroxide complexes. When the ratio exceeded 2.0, suspended gibbsite crystals about $0.10 \mu$ (microns) in diameter could be detected in the solutions after 10 days of aging. Smaller aggregates and monomeric ions were also present.

The properties of the solutions and the suspended or dissolved material that had formed in them after 10 days continued to change slowly with further aging. The $\mathrm{pH}$ generally tended to decrease, with little or no change in the total concentration of the monomeric dissolved aluminum. This effect was attributed to an increasing orderliness of the polymerized material which resulted as the hydroxide in the polymer was incorporated into bridging positions between the aluminum ions. Bridging hydroxide presumably would not be involved in $\mathrm{H}^{+-} \mathrm{OH}^{-}$equilibria in the solution. Somewhat similar effects can be expected as the crystalline particles grow in size. The longest aging time in the solution studies by Hem and Roberson was between 4 and 5 months.

A more extensive and detailed study of the aging process, with longer aging times, was undertaken by the senior author in order to evaluate more closely the chemistry of the polymerization process and explore more fully the nature of unstable aluminum species. The results of the work are summarized in this paper and are given in greater detail in a larger paper by Smith (1969). The results of these experiments, which involved some solutions aged as long as 3 years, show that the solid formed in solutions whose $\mathrm{pH}$ is below neutrality eventually attains a solubility similar to that of bayer:te which is formed relatively rapidly in alkaline solutions and which characteristically consists of crystals that are $1.0 \mu$ or more in diameter (Hem and Roberson, 1967; Schoen and Roberson, 1970). The greater solubility of microcrystalline gibbsite that forms earlier in the aging process is essentially a particle-size effect.

Although microcrystalline gibbsite is metastable, it is altered very slowly in solutions similar to natural water and therefore has considerable significance in the chemistry of aluminum in natural systems. 
The approach used in this study was to identify as closely as possible the form of all dissolved aluminum species and to follow the changes in concentration of each with time. The $\mathrm{pH}$ of all so'utions also was measured when aluminum determinations were made.

Recently the form of aluminum in acid aqueous media has been studied by several investigators using timed spectrophotometric procedures (Smith, 1969; Smith, 1970; Turner, 1969). Using similar analytical techniques both Smith and Turner conclude that in such systems aluminum can be present (often simultaneously) in three distinct forms. Smith designated these forms $\mathrm{Al}^{\mathrm{a}}, \mathrm{Al}^{\mathrm{b}}$, and $\mathrm{Al}^{\mathrm{c}}$. Form $\mathrm{Al}^{\text {a }}$ consists of simple monomeric dissolved species such as $\mathrm{Al}\left(\mathrm{H}_{2} \mathrm{O}\right)_{6}{ }^{+3}$, $\mathrm{Al}(\mathrm{OH})\left(\mathrm{H}_{2} \mathrm{O}\right)_{5}{ }^{+2}, \mathrm{Al}(\mathrm{OH})_{2}\left(\mathrm{H}_{2} \mathrm{O}\right)_{4}{ }^{+}$, and $\mathrm{Al}(\mathrm{OH})_{4}{ }^{-}$; form $\mathrm{Al}^{\mathrm{b}}$ consists of polynuclear solute species with $\mathrm{OH}: \mathrm{Al}>2.0$; and form $\mathrm{Al}^{\mathrm{c}}$ consists of submicroscopic crystalline particles of $\mathrm{Al}(\mathrm{OH})_{3}$ displaying the characteristic behavior of a solid.

\section{EXPERIMENTAL TECHNIQUES}

The work was initiated by preparing a series of solutions containing the same total concentration of aluminum but differing amounts of added base and by determining the composition and $\mathrm{pH}$ of the solutions after various periods of aging. For convenience, the se solutions will be designated "aging-study solutions." Electron microscopy was used to help determine the nature of colloidal material that formed in some of the solutions.

The solutions studied all contained $4.54 \times 10^{-4}$ moles/liter aluminum and total ionic strength was $10^{-2}$, the remainder of the total ionic strength being sodium and perchlorate ions. The $\mathrm{OH}: \mathrm{Al}$ ratio in the solutions as made up (nominal $r$ value or $r_{n}$ ) varied from 0.55 to 3.01. In preparing these aging-study solutions, three standard solutions were prepared initially and mixed together in corr act proportion to achieve the desired $r_{n}$ value. These solutions were designated solutions 1,2 , and 3 . The procedure for doing this has been described by Hem and Roberson (1967). The solution containing base, but no aluminum (solution 2 ), was always added last in solution preparation. Reagent grade chemicals were used throughout. Solutions were prepared having $r_{n}$ values of $0.55,0.94,1.36,1.84,2.13,2.47$, 2.76 , and 3.01 and were designated, respectively, solutions $\mathrm{R}, \mathrm{C}, \mathrm{D}$, E, F, G, H, and J. At various aging times aliquots of the solutions were analyzed for amounts of $\mathrm{Al}^{\mathrm{a}}, \mathrm{Al}^{\mathrm{b}}$ and $\mathrm{Al}^{\mathrm{c}}$. The procedure used for determination of the three types of aluminum was that described by Smith $(1969,1970)$. The procedure depends on the variation of rate and type of reaction of the three forms of aluminum with ferron (7-iodo-8-hydroxyquinoline-5-sulfonic acid). At the same time $\mathrm{pH}$ of the solutions was measured. 
TABLE 1.-Concentrations of various types of aluminum in relation to age

[Concentration $\times 10^{-4}$ moles per liter. Asterisk indicates old solution of similar makeup]

\begin{tabular}{|c|c|c|c|c|c|c|c|c|c|}
\hline Age & $\mathrm{Al}^{\mathrm{s}}$ & $A l^{b}$ & $\mathrm{Al}^{\mathrm{e}}$ & $\mathrm{pH}$ & Age & $\mathrm{Al} \mathbf{s}$ & $A l^{b}$ & $\mathbf{A l} \mathbf{l}^{\mathrm{c}}$ & $\mathrm{pH}$ \\
\hline \multicolumn{5}{|c|}{$\begin{array}{l}\text { Solution B } \\
{\left[r_{n}=0.55\right]}\end{array}$} & \multicolumn{5}{|c|}{$\begin{array}{c}\text { Solution F } \\
{\left[r_{n}=2.13\right]}\end{array}$} \\
\hline $\begin{array}{c}\text { Hours } \\
1.1 \\
23 \\
48 \\
168 \\
505 \\
\text { Days }\end{array}$ & $\begin{array}{l}3.90 \\
3.64 \\
3.69 \\
3.57 \\
3.72\end{array}$ & $\begin{array}{r}0.31 \\
.57 \\
.40 \\
.54 \\
.64\end{array}$ & $\begin{array}{r}0.34 \\
.34 \\
.46 \\
.44 \\
.19\end{array}$ & $\begin{array}{l}4.46 \\
4.44 \\
4.49 \\
4.45 \\
4.46\end{array}$ & $\begin{array}{r}\text { Hours } \\
1.2 \ldots \\
23 . \ldots \\
96 \\
168 \\
288 \\
625\end{array}$ & $\begin{array}{l}1.46 \\
1.11 \\
1.12 \\
1.12 \\
1.05 \\
1.05\end{array}$ & $\begin{array}{l}1.78 \\
2.05 \\
1.86 \\
1.86 \\
1.82 \\
1.35\end{array}$ & $\begin{array}{l}1.30 \\
1.38 \\
1.56 \\
1.56 \\
1.67 \\
2.04\end{array}$ & $\begin{array}{l}4.88 \\
4.75 \\
4.63 \\
4.60 \\
4.52 \\
4.42\end{array}$ \\
\hline $\begin{array}{r}41 \\
77 \ldots \\
116 \\
188 \ldots \\
254 \ldots \\
1001^{*} \ldots \ldots \\
\end{array}$ & $\begin{array}{l}3.84 \\
3.80 \\
3.76 \\
3.77 \\
3.56 \\
3.75 \\
\end{array}$ & $\begin{array}{l}.48 \\
.50 \\
.35 \\
.32 \\
.59 \\
.11\end{array}$ & $\begin{array}{l}.23 \\
.25 \\
.44 \\
.46 \\
.40 \\
.69\end{array}$ & $\begin{array}{l}4.43 \\
4.43 \\
4.43 \\
4.42 \\
4.43 \\
4.43\end{array}$ & $\begin{array}{c}\text { Days } \\
46 \\
82 \\
121 \\
193 \\
259 \\
967\end{array}$ & $\begin{array}{l}1.02 \\
1.20 \\
1.21 \\
1.07 \\
1.02 \\
1.16\end{array}$ & $\begin{array}{l}.78 \\
.26 \\
.10 \\
.04 \\
.02 \\
. .\end{array}$ & $\begin{array}{l}2.74 \\
3.08 \\
3.23 \\
3.43 \\
3.50 \\
3.33\end{array}$ & $\begin{array}{l}4.37 \\
4.30 \\
4.28 \\
4.22 \\
4.20 \\
4.19\end{array}$ \\
\hline \multicolumn{5}{|c|}{$\begin{array}{l}\text { Solution C } \\
{\left[r_{n}=0.94\right]}\end{array}$} & \multicolumn{5}{|c|}{$\begin{array}{c}\text { Solution } \mathbf{G} \\
{\left[r_{n}=2.47\right]}\end{array}$} \\
\hline $\begin{array}{c}\text { Hours } \\
1.5 \ldots \\
23 . \\
96 \\
168 \\
288 \\
625 \\
\text { Days }\end{array}$ & $\begin{array}{l}3.40 \\
3.24 \\
3.20 \\
3.31 \\
3.12 \\
2.94\end{array}$ & $\begin{array}{l}0.65 \\
.94 \\
1.06 \\
1.10 \\
1.00 \\
1.19\end{array}$ & $\begin{array}{r}0.49 \\
.36 \\
.28 \\
.13 \\
.42 \\
.42\end{array}$ & $\begin{array}{l}4.52 \\
4.46 \\
4.43 \\
4.43 \\
4.46 \\
4.48\end{array}$ & $\begin{array}{c}\text { Hours } \\
1.2 . \\
23 \\
48 \\
168 \\
505 \\
\text { Days }\end{array}$ & $\begin{array}{r}1.17 \\
.60 \\
.60 \\
.55 \\
.64\end{array}$ & $\begin{array}{r}1.97 \\
1.20 \\
1.15 \\
1.05 \\
.81\end{array}$ & $\begin{array}{l}1.40 \\
2.74 \\
2.79 \\
2.94 \\
3.09\end{array}$ & $\begin{array}{l}5.02 \\
4.82 \\
4.77 \\
4.75 \\
4.49\end{array}$ \\
\hline $\begin{array}{r}46 \\
82 \\
121 \\
193 \\
259 \\
1038^{*} \ldots \ldots\end{array}$ & $\begin{array}{l}3.35 \\
3.20 \\
3.23 \\
3.07 \\
3.10 \\
3.23\end{array}$ & $\begin{array}{r}1.14 \\
.97 \\
.79 \\
.65 \\
.76 \\
.43\end{array}$ & $\begin{array}{l}.05 \\
.37 \\
.52 \\
.82 \\
.68 \\
.89\end{array}$ & $\begin{array}{l}4.46 \\
4.48 \\
4.47 \\
4.47 \\
4.47 \\
4.36\end{array}$ & $\begin{array}{r}41 \\
77 \\
116 \\
188 \ldots \\
254 \ldots \\
389^{*} \ldots \ldots\end{array}$ & $\begin{array}{l}.68 \\
.68 \\
.66 \\
.61 \\
.62 \\
.46\end{array}$ & $\begin{array}{l}.40 \\
.13 \\
.043 \\
.019 \\
.007 \\
--\end{array}$ & $\begin{array}{l}3.46 \\
3.63 \\
3.84 \\
3.91 \\
3.91 \\
4.68\end{array}$ & $\begin{array}{l}4.42 \\
4.40 \\
4.35 \\
4.31 \\
4.28 \\
4.29\end{array}$ \\
\hline \multicolumn{5}{|c|}{$\begin{array}{c}\text { Solution D } \\
{\left[r_{n}=1.36\right]}\end{array}$} & \multicolumn{5}{|c|}{$\begin{array}{c}\text { Solution } \mathbf{H} \\
{\left[r_{n}=2.76\right]}\end{array}$} \\
\hline $\begin{array}{c}\text { Hours } \\
1.3 \\
23 . \\
96 \\
168 \\
288 \\
625 \\
\text { Days }\end{array}$ & $\begin{array}{l}2.84 \\
2.50 \\
2.42 \\
2.32 \\
2.35 \\
2.30\end{array}$ & $\begin{array}{l}1.06 \\
1.58 \\
1.54 \\
1.62 \\
1.66 \\
1.63\end{array}$ & $\begin{array}{r}0.64 \\
.46 \\
.58 \\
.60 \\
.53 \\
.61\end{array}$ & $\begin{array}{l}4.66 \\
4.56 \\
4.52 \\
4.49 \\
4.49 \\
4.40\end{array}$ & $\begin{array}{c}\text { Hours } \\
1.1 \\
23 . \\
96 . \cdots \\
168 \\
288 \\
625 \\
\text { Days }\end{array}$ & $\begin{array}{l}0.78 \\
.20 \\
.20 \\
.23 \\
.24 \\
.24\end{array}$ & $\begin{array}{r}1.36 \\
.50 \\
.40 \\
.39 \\
.36 \\
.30\end{array}$ & $\begin{array}{l}3.40 \\
3.84 \\
3.94 \\
3.92 \\
3.94 \\
4.00\end{array}$ & $\begin{array}{l}5.23 \\
5.16 \\
5.00 \\
4.76 \\
4.72 \\
4.62\end{array}$ \\
\hline $\begin{array}{r}46 \ldots \\
82 . \ldots \\
121 \\
193 \ldots \\
259 \ldots \\
1038^{*} \ldots \ldots\end{array}$ & $\begin{array}{l}2.31 \\
2.34 \\
2.39 \\
2.43 \\
2.30 \\
2.46\end{array}$ & $\begin{array}{r}1.11 \\
.34 \\
.06 \\
.09 \\
.02 \\
--\end{array}$ & $\begin{array}{l}1.12 \\
1.86 \\
2.09 \\
2.02 \\
2.22 \\
2.08\end{array}$ & $\begin{array}{l}4.32 \\
4.26 \\
4.23 \\
4.14 \\
4.12 \\
4.09\end{array}$ & $\begin{array}{r}46 \\
82 \\
121 \\
193 \ldots \\
259\end{array}$ & $\begin{array}{l}.28 \\
.29 \\
.284 \\
.232 \\
.235\end{array}$ & $\begin{array}{l}.17 \\
.05 \\
.011 \\
.008 \\
--\end{array}$ & $\begin{array}{l}4.09 \\
4.20 \\
4.24 \\
4.30 \\
4.30\end{array}$ & $\begin{array}{l}4.53 \\
4.51 \\
4.49 \\
4.45 \\
4.45\end{array}$ \\
\hline \multicolumn{5}{|c|}{$\begin{array}{c}\text { Solution E } \\
{\left[r_{n}=1.84\right]}\end{array}$} & \multicolumn{5}{|c|}{$\begin{array}{c}\text { Solution J } \\
{\left[r_{n}=3.01\right]} \\
\end{array}$} \\
\hline $\begin{array}{c}\text { Hours } \\
1.0 \ldots \\
23 \\
48 \\
168 \\
505 \\
\text { Days }\end{array}$ & $\begin{array}{l}2.24 \\
1.56 \\
1.82 \\
1.46 \\
1.44\end{array}$ & $\begin{array}{l}1.50 \\
2.10 \\
2.00 \\
1.86 \\
2.14\end{array}$ & $\begin{array}{r}0.50 \\
.88 \\
.72 \\
1.22 \\
.96\end{array}$ & $\begin{array}{l}4.79 \\
4.68 \\
4.66 \\
4.61 \\
4.56\end{array}$ & $\begin{array}{c}\text { Hours } \\
1.0 \ldots \\
23 \\
48 \\
168 \\
505\end{array}$ & $\begin{array}{r}0.56 \\
.08 \\
.07 \\
.05 \\
.05\end{array}$ & $\begin{array}{r}1.90 \\
.22 \\
.16 \\
.07 \\
.03\end{array}$ & $\begin{array}{l}2.08 \\
4.24 \\
4.31 \\
4.42 \\
4.46\end{array}$ & $\begin{array}{l}7.15 \\
6.64 \\
6.59 \\
6.52 \\
6.54\end{array}$ \\
\hline $\begin{array}{r}41 \\
716 \\
1168 \\
1854 \\
1038 * \ldots\end{array}$ & $\begin{array}{l}1.50 \\
1.53 \\
1.60 \\
1.51 \\
1.50 \\
1.79\end{array}$ & $\begin{array}{r}1.81 \\
1.45 \\
1.20 \\
.49 \\
.12 \\
-.\end{array}$ & $\begin{array}{l}1.23 \\
1.56 \\
1.74 \\
2.54 \\
2.92 \\
2.77\end{array}$ & $\begin{array}{l}4.54 \\
4.54 \\
4.52 \\
4.44 \\
4.32 \\
4.13\end{array}$ & $\begin{array}{c}\text { Days } \\
41 \\
77 \\
116\end{array}$ & $\begin{array}{l}.065 \\
.08 \\
.057 \\
.019\end{array}$ & $\begin{array}{c}.01 \\
-- \\
-- \\
-\end{array}$ & $\begin{array}{l}4.47 \\
4.46 \\
4.48 \\
4.52\end{array}$ & $\begin{array}{l}6.43 \\
6.28 \\
6.40 \\
6.21\end{array}$ \\
\hline
\end{tabular}

Table 1 lists the values of $\mathrm{Al}^{\mathrm{a}}, \mathrm{Al}^{\mathrm{b}}, \mathrm{Al}^{\mathrm{c}}$, and $\mathrm{pH}$ obtained for the solutions at various aging times. The "old" solutions were solutions of somewhat similar composition that had been prepar?d 1 year previously. It should be noted that for most solutions $\mathrm{Al}^{\text {a }}$ remains virtually constant after 23 hours' aging and that $\mathrm{Al}^{\mathrm{b}}$ decreases and 
$\mathrm{Al}^{\mathrm{l}}$ increases as functions of aging time. Values for $\mathrm{Al}^{\mathrm{a}}$ from the various solutions are listed in table 2 , and the relationship between initial $r$ value $\left(r_{n}\right)$ and $\mathrm{Al}^{\text {a }}$ value is shown graphically in figure 1.

TABLE 2.-Concentrations of monomeric aluminum ( $\left.\mathrm{Al}^{\mathrm{a}}\right)$

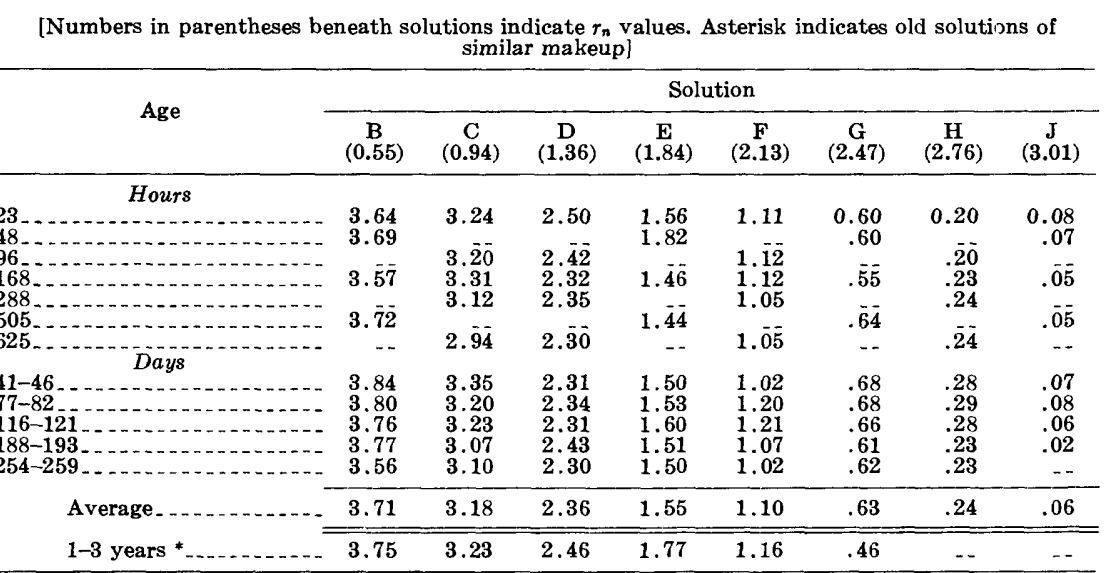

\section{CHARACTERISTICS OF Al}

The form of aluminum, $\mathrm{Al}^{\mathrm{a}}$, that reacts almost instantly with ferron can be reasonably assumed to consist of only simple monomeric species; that is, $\mathrm{Al}^{+3}, \mathrm{Al}(\mathrm{OH})^{+2}, \mathrm{Al}(\mathrm{OH})_{2}{ }^{+}$, and $\mathrm{Al}(\mathrm{OH})_{4}^{-}$, with appropriate coordinated water molecules. These forms do not include any bridging hydroxide, which was shown by Hem and Roberson (1967) to stabilize the structure of aluminum hydroxide pclymers and make them slow to react to changes in the solution. Standard Gibbs free energies of formation $\left(\Delta G^{\circ}\right)$ for the monomeric species are available in the chemical literature. Table 3 lists some of these values, in kilocalories, plus a Gibbs free energy value for gibbsite, $\alpha \mathrm{Al}(\mathrm{OH})_{3}$, taken from the literature. This value corresponds to the most. negative values for $\Delta G^{\circ}$ for aluminum hydroxide solids reported by Hem and Roberson (1967).

Concentrations of $\mathrm{Al}^{\text {a }}$ measured in the aging solutions can be assigned to the four monomeric solute species by chemical equilibrium

TABLE 3.--Gibbs free energies of formation of monomeric aluminum species

\begin{tabular}{|c|c|c|}
\hline Species & $\begin{array}{l}\text { Standard Gibbs } \\
\text { free energies } \\
\text { of formation } \\
\text { ( } \Delta G^{\circ} \text { kcal) }\end{array}$ & Source \\
\hline $\begin{array}{l}\mathrm{Al}+3 \\
\mathrm{Al}(\mathrm{OH})^{+2} \\
\mathrm{Al}(\mathrm{OH})_{2}{ }^{+}\end{array}$ & $\begin{array}{l}-115.0 \\
-164.9 \\
-215.1 \\
-311.7 \\
-273.9\end{array}$ & $\begin{array}{l}\text { Latimer (1952). } \\
\text { Raupach (1963a, b). } \\
\text { Do. } \\
\text { Hem and Roberson (1967). } \\
\text { Latimer (1952). }\end{array}$ \\
\hline
\end{tabular}




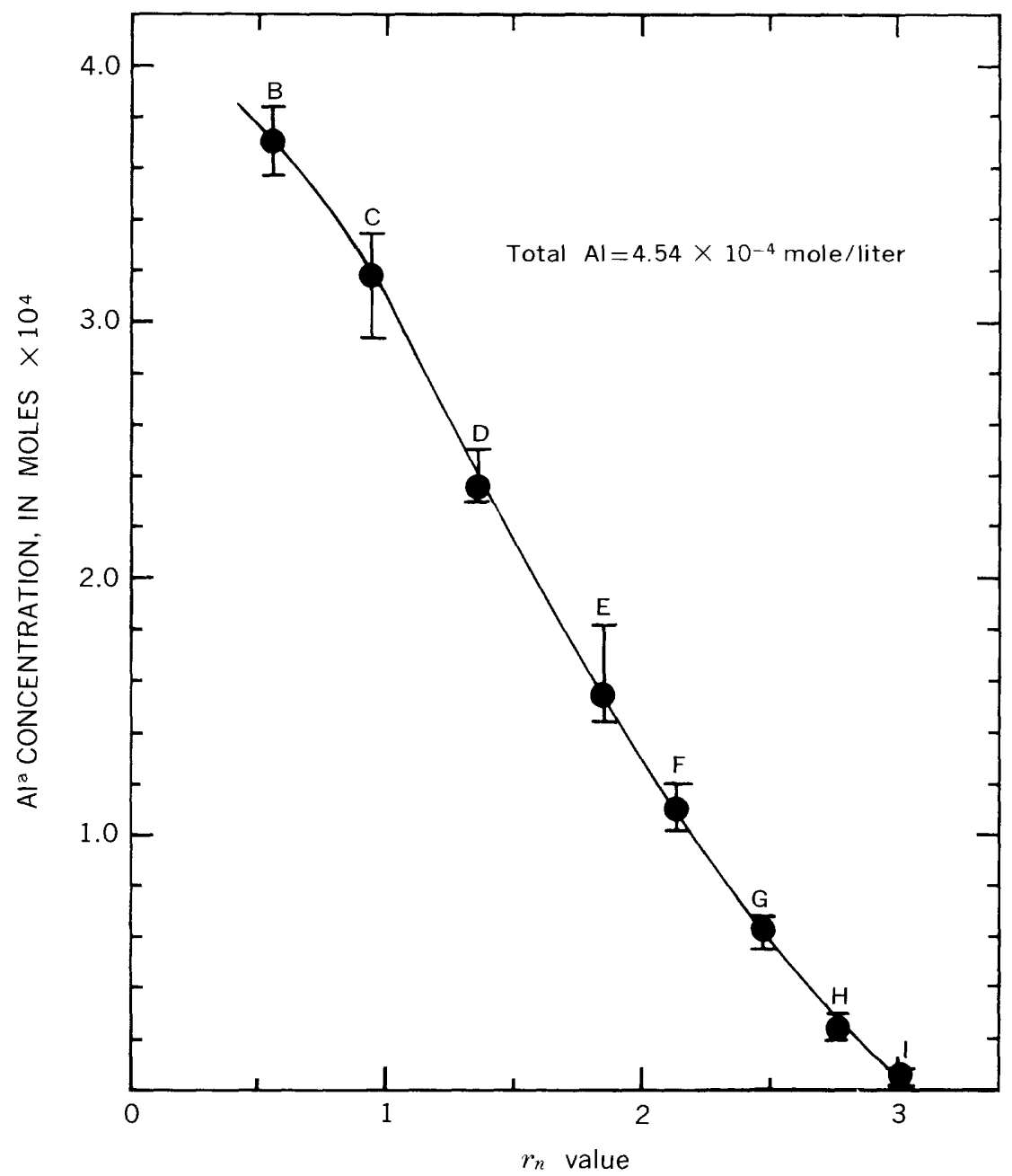

FIGURE 1.-Concentration of $\mathrm{Al}^{\mathrm{a}}$ as a function of $r_{n}$ value.

calculations, based on earlier, more detailed investigations of these forms.

The Gibbs free energy values for $\mathrm{Al}^{+3}, \mathrm{Al}(\mathrm{OH})^{+2}$ and $\mathrm{Al}(\mathrm{OH})_{4}^{-}$ were selected to be consistent with the work of Hem and Roberson (1967). Few values for $\mathrm{Al}(\mathrm{OH})_{2}{ }^{+}$were available, and Raupach's was selected for consistency because of the use of his value for $\mathrm{Al}(\mathrm{OH})^{+2}$.

Hem and Roberson (1967) determined a value of $10^{-4.75}$ for $* K_{1}$ (the first hydrolysis constant of $\mathrm{Al}^{+3}$ ) and reported that this gave a satisfactory fit of their data without considering the species $\mathrm{Al}(\mathrm{OH})_{2}{ }^{+}$. The calculations here were refined by including both $\mathrm{Al}(\mathrm{OH})^{+2}$ and 
$\mathrm{Al}(\mathrm{OH})_{2}{ }^{+}$species, but the total amount of hydroxide bound in $\mathrm{Al}^{\mathrm{a}}$ species comes out about the same by either procedure.

From data of table 3 the following can be written:

$$
\begin{aligned}
& \alpha \mathrm{Al}(\mathrm{OH})_{3}+3 \mathrm{H}^{+} \rightleftarrows \mathrm{Al}^{+3}+3 \mathrm{H}_{2} \mathrm{O} \\
& * K_{\mathrm{S}_{0}}=10^{+8.22} \\
& \alpha \mathrm{Al}(\mathrm{OH})_{3}+2 \mathrm{H}^{+} \rightleftarrows \mathrm{AlOH}+2+2 \mathrm{H}_{2} \mathrm{O} \\
& * K_{S \mathrm{SI}}=10^{+3.22} \\
& \alpha \mathrm{Al}(\mathrm{OH})_{3}+\mathrm{H}^{+} \rightleftarrows \mathrm{Al}(\mathrm{OH})_{2}++\mathrm{H}_{2} \mathrm{O} \\
& * K_{\mathrm{S} 2}=10^{-1.54} \\
& \alpha \mathrm{Al}(\mathrm{OH})_{3}+\mathrm{H}_{2} \mathrm{O} \rightleftarrows \mathrm{Al}(\mathrm{OH})_{4}{ }^{-}+\mathrm{H}^{+} \\
& * K_{S 4}=10^{-13.9} \\
& \mathrm{Al}{ }^{+3}+\mathrm{H}_{2} \mathrm{O} \rightleftarrows \mathrm{Al}(\mathrm{OH})^{+2}+\mathrm{H}^{+} \\
& * K_{\mathrm{I}}=10^{-5.00} \\
& \mathrm{Al}(\mathrm{OH})^{+2}+\mathrm{H}_{2} \mathrm{O} \rightleftarrows \mathrm{Al}(\mathrm{OH})_{2}{ }^{+}+\mathrm{H}^{+} \\
& * K_{2}=10^{-4.76}
\end{aligned}
$$

Using the above equations plus estimated activity coefficients (table 4), the theoretical concentrations of the monomeric snecies can be calculated and plotted as a function of $\mathrm{pH}$. Further, actual concentrations of $\mathrm{Al}^{\text {a }}$ for the various solutions and aging times can be plotted on the same chart. This combined plot is shown in figure 2. Increasing aging time is indicated by the arrows.

\begin{tabular}{|c|c|}
\hline Species & Coefficient \\
\hline 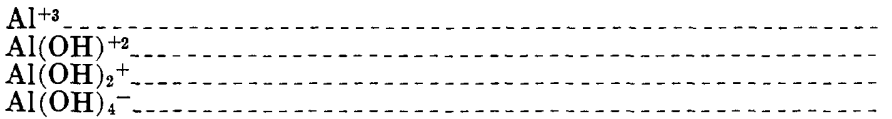 & $\begin{array}{r}0.42 .7 \\
2.678 \\
2.907 \\
3.8 \subseteq 0\end{array}$ \\
\hline
\end{tabular}

Figure 2 shows that $\mathrm{Al}^{\text {a }}$ concentration remains nearly constant while $\mathrm{pH}$ drops, at least for solutions $\mathrm{D}-\mathrm{H}$, as a function of aging time until the theoretical equilibrium line for $\mathrm{Al}^{+3}+\mathrm{Al}(\mathrm{OH})^{+2}+$ $\mathrm{Al}(\mathrm{OH})_{2}{ }^{+}+\mathrm{Al}(\mathrm{OH})_{4}{ }^{-}$is reached. The sum of the $\mathrm{Al}^{\text {a }}$ species thus conforms to the thermodynamic solubility of gibbsite.

Figure 3 shows curves similar to those of figure 2 except that $\mathrm{Al}^{\mathrm{a}}{ }^{\mathrm{b}}$ concentrations are plotted rather than $\mathrm{Al}^{\mathrm{a}}$ concentrations alone. The trend of the total aluminum concentrations in figure 3 is downward during aging, owing to decreases in $\mathrm{Al}^{b}$.

From equations 1-6 and the several activity coefficients it is also

TABLE 4.-Activity coefficients of monomeric species for $\sim 10^{-2}$ ionic strength solutions

1 From Debye-Hückel limiting law using parameter a $=9$

2 From Debye-Hückel limiting law using parameter $a=6$.

3 From Debye-Hückel limiting law using parameter $\mathbf{a}=\mathbf{3}$.

NOTE. - The use of the above values for parameter a is in accord with Butler (1964). The activity coefficients used for $A l^{+3}$ and $\mathrm{Al}(\mathrm{OH})^{+2}$ were identical to the values used by Hem and Robers on (1967) for similar solutions. 


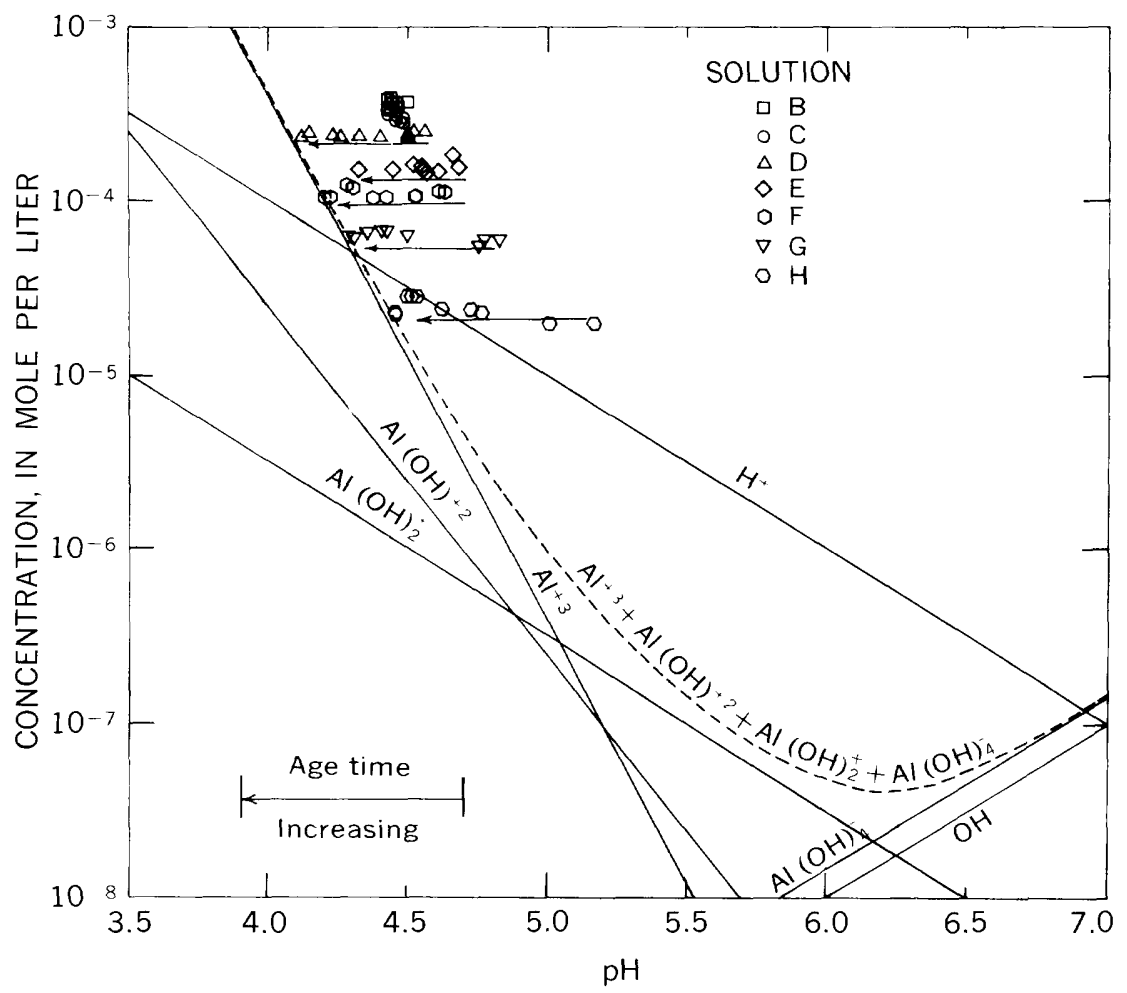

FIgURE 2.-Concentration of $\mathrm{Al}^{\mathrm{a}}$ as a function of $\mathrm{pH}$ for solutions $\mathrm{B}-\mathrm{H}$ at various aging times.

possible to calculate activities of the various possible monomeric species at all aging times using formulas of the type:

$$
\left[\mathrm{Al}^{+3}\right]=\frac{\mathrm{Al}^{\mathrm{a}}}{2.34+\frac{1.47 \times 10^{-5}}{\left[\mathrm{H}^{+}\right]}+\frac{1.91 \times 10^{-10}}{\left[\mathrm{H}^{+}\right]^{2}}+\frac{7.6 \times 10^{-23}}{\left[\mathrm{H}^{+}\right]^{4}}},
$$

where $\left[\mathrm{H}^{+}\right]$is hydrogen ion activity. Such formulas are derived from complexing equilibria and stoichiometric or ion-balance equations like those described by Hem (1968) for aluminum fluoride systems. The calculated activity values can then be plotted on a graph of log activity as a function of aging time. These plots are shovn in figures 4-11. Equilibrium lines shown are based on equations 1-4.

Note for solutions D, E, F, G, and $\mathrm{H}$ that all species move toward the equilibrium lines with increasing aging time. The data from other, older solutions similar to $\mathrm{B}$ and $\mathrm{C}$ (darkened points) indicate that these solutions, too, are very slowly moving toward equilibrium. 


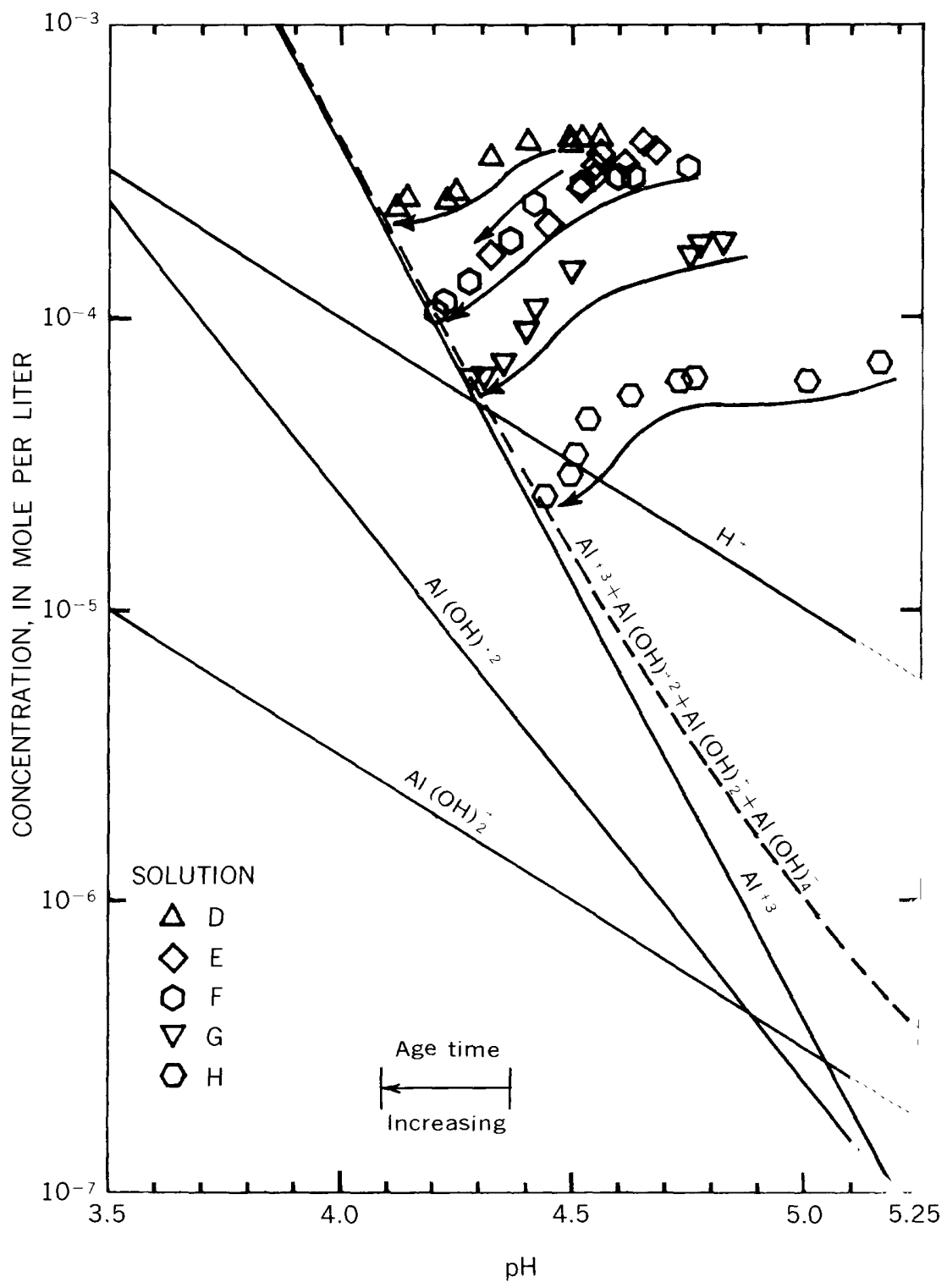

FIgURE 3.-Concentration of $\mathrm{Al}^{\mathrm{a}+\mathrm{b}}$ as a function of $\mathrm{pH}$ at various aging times.

Solution $\mathbf{J}$ with its high $r_{n}$ value is acting in a somewhat different manner, although there is evidence that it also is moving toward proper equilibrium values.

The experimental results consistently show that for each solution the total concentration of monomeric aluminum remains constant 


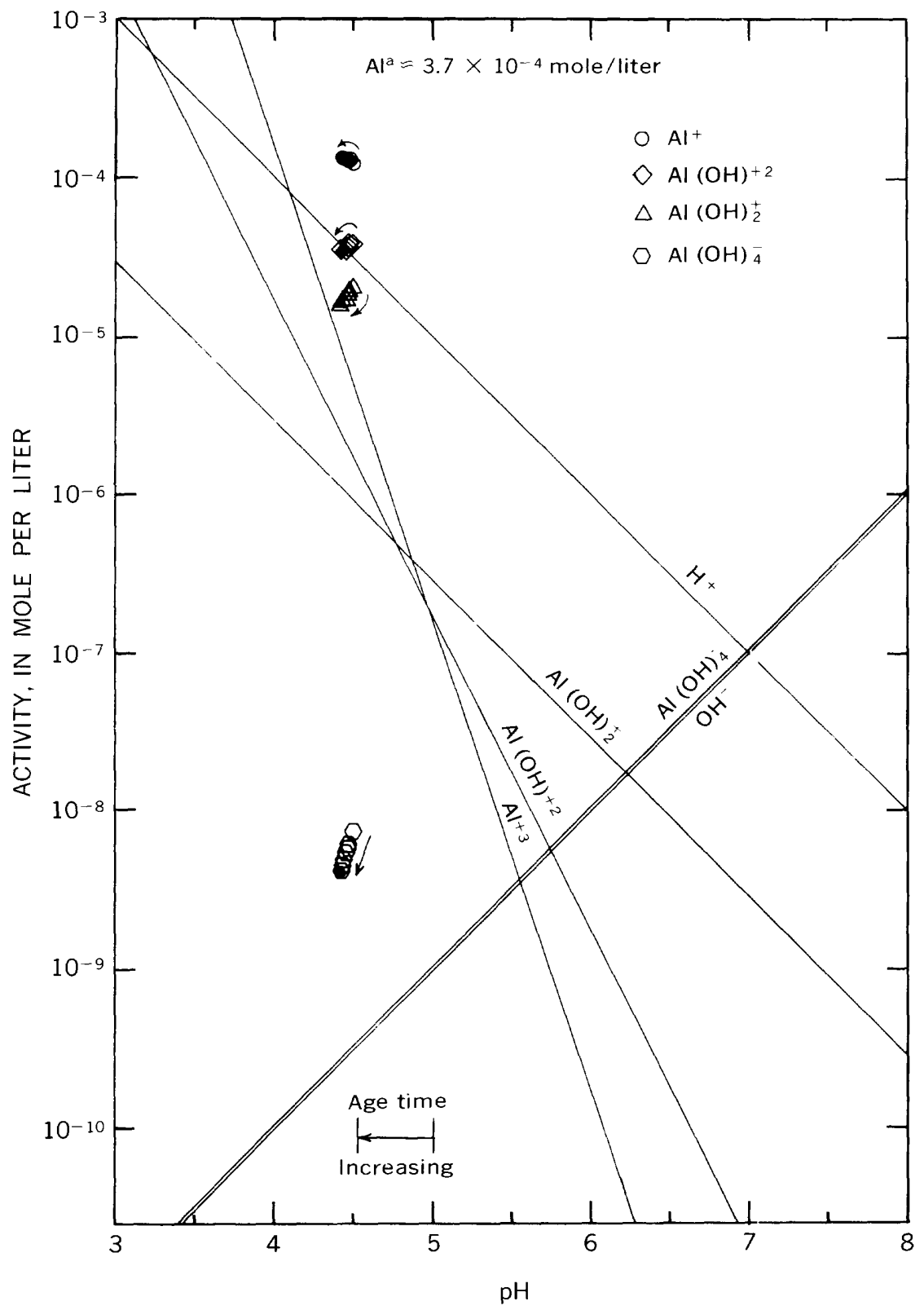

FIGURE 4.-Aging time effect on activity of monomeric species as a function of $\mathrm{pH}$ for solution $B$. 


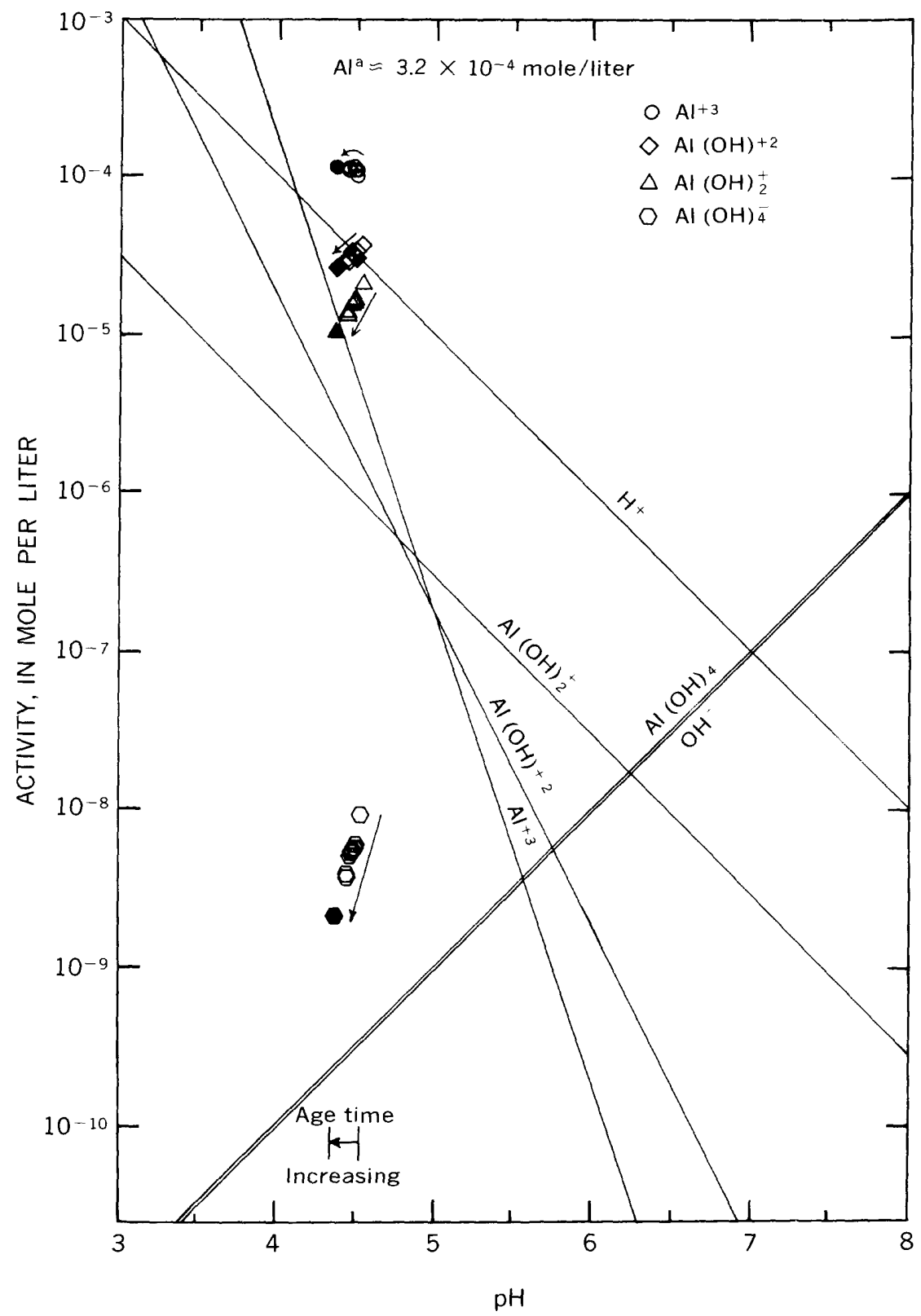

FIGURE 5.-Aging time effect on activity of monomeric species as a function of $\mathrm{pH}$ for solution $\mathrm{C}$. 


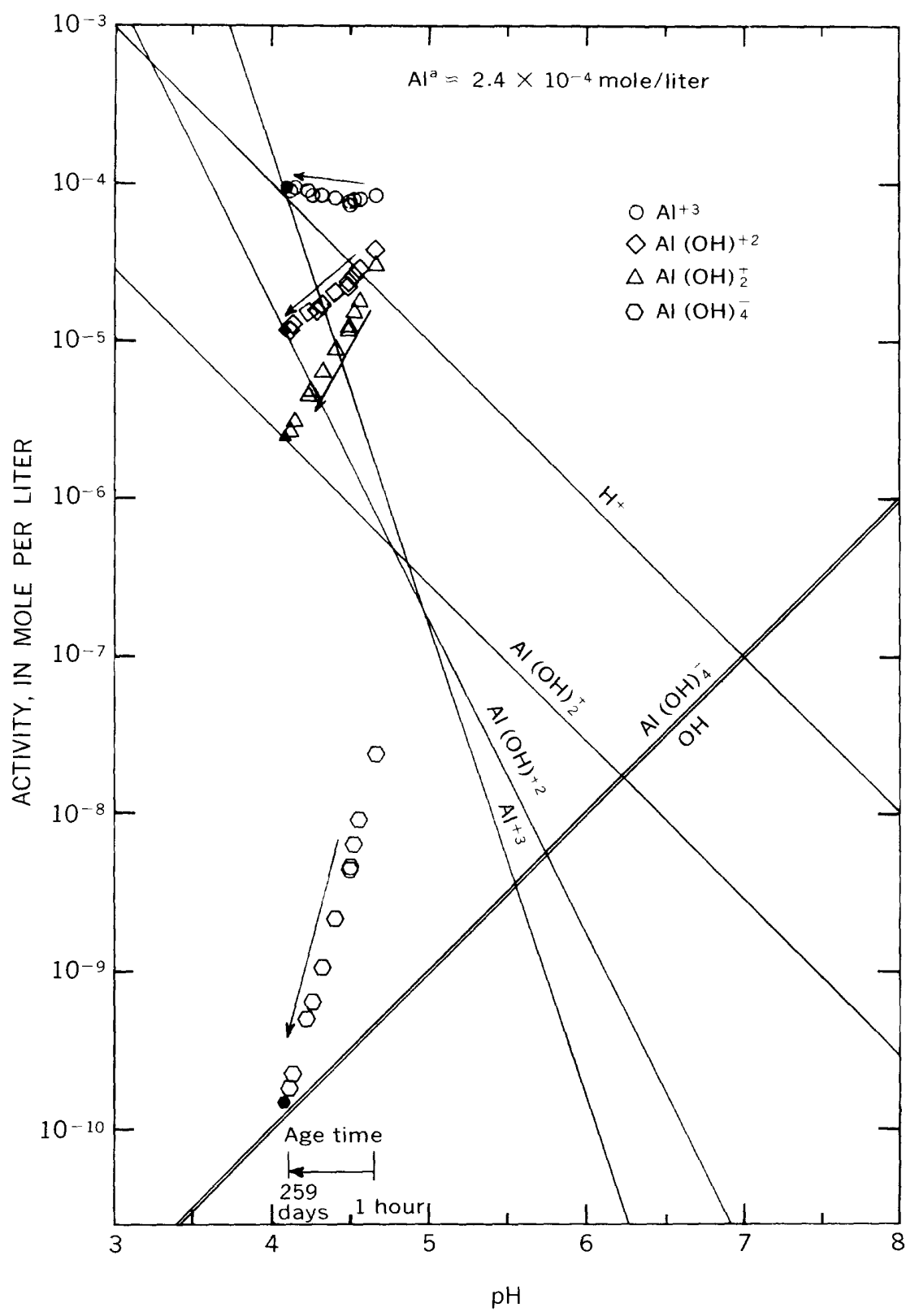

FIGURE 6.-Aging time effect on activity of monomeric species as a furction of $\mathrm{pH}$ for solution D. 


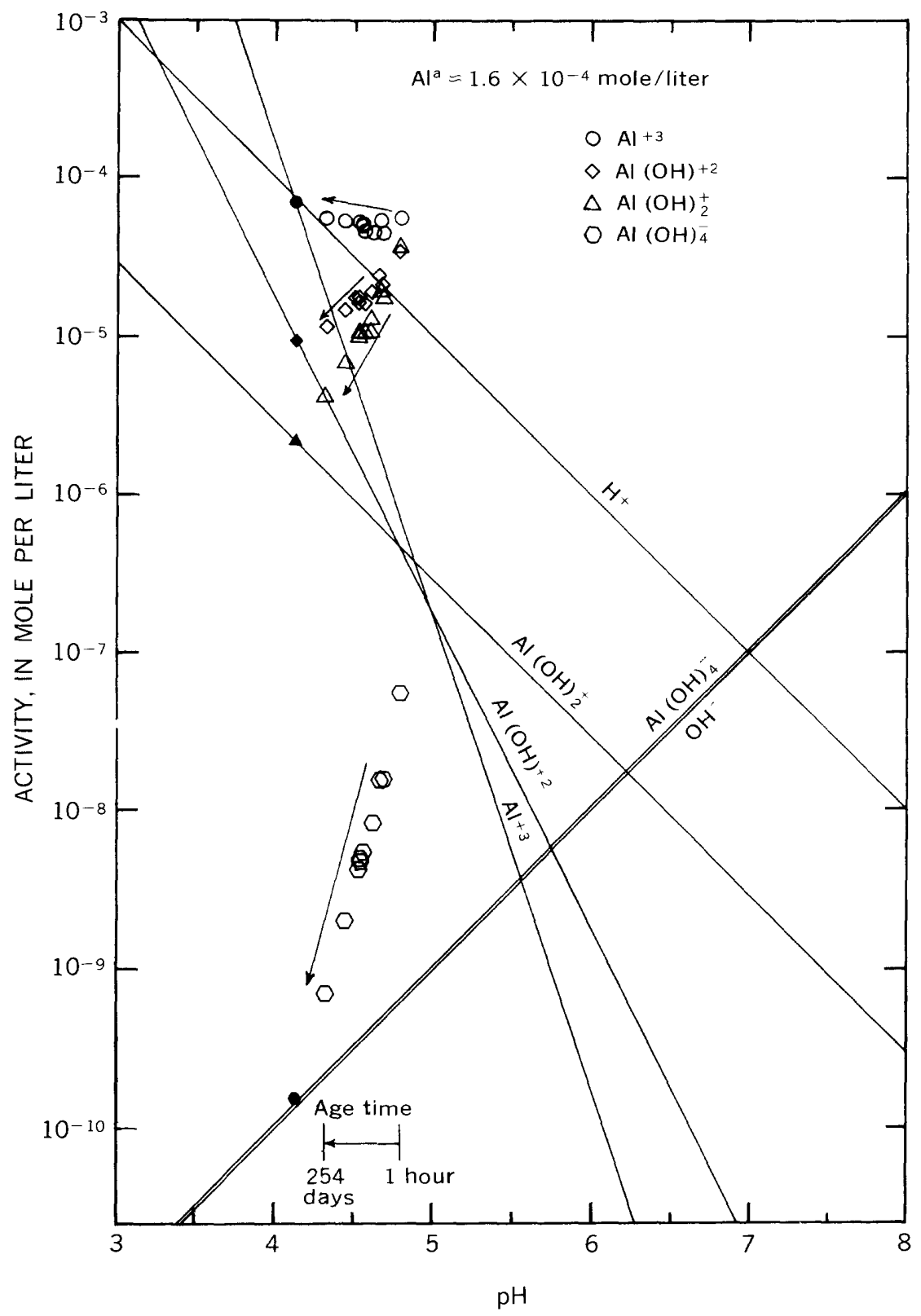

FIgURE 7.--Aging time effect on activity of monomeric species as a function of $\mathrm{pH}$ for solution $\mathrm{E}$. 
D14 CHEMISTRY OF ALUMINUM IN NATURAL WATTR

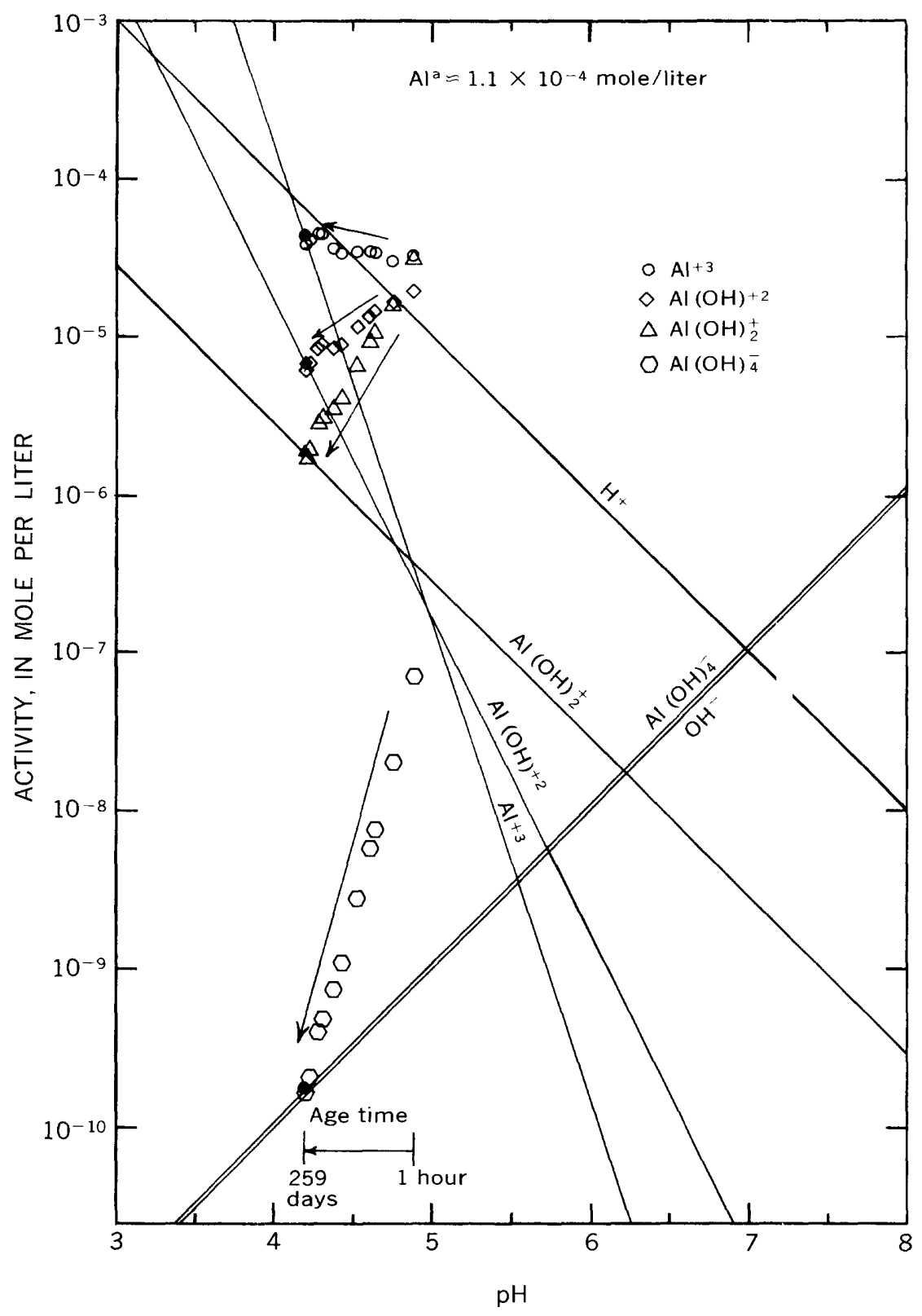

FIGURE 8.-Aging time effect on activity of monomeric species as a function of $\mathrm{pH}$ for solution $\mathrm{F}$. 


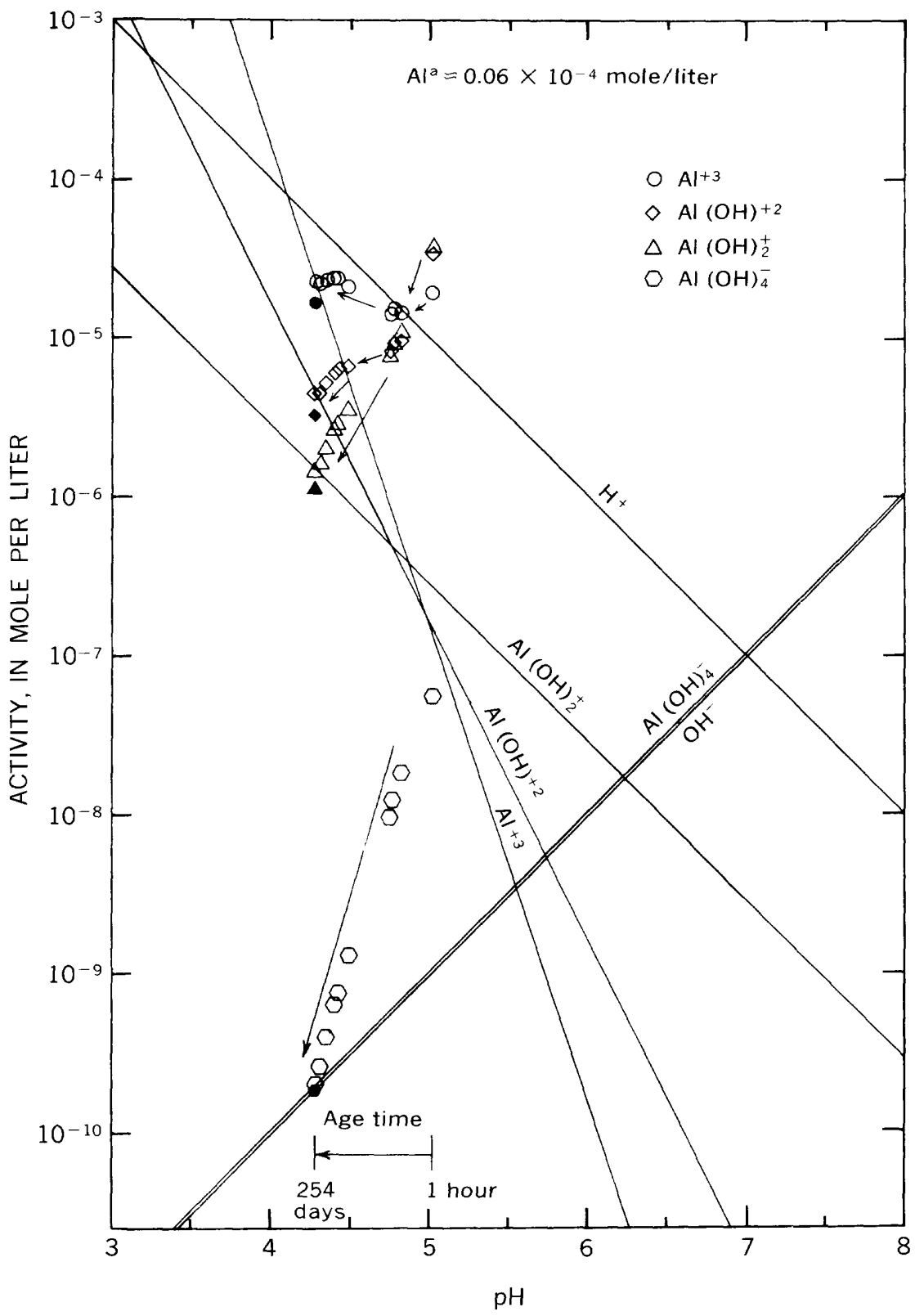

Figure 9.-Aging time effect on activity of monomeric species as a function of $\mathrm{pH}$ for solution $\mathrm{G}$. 


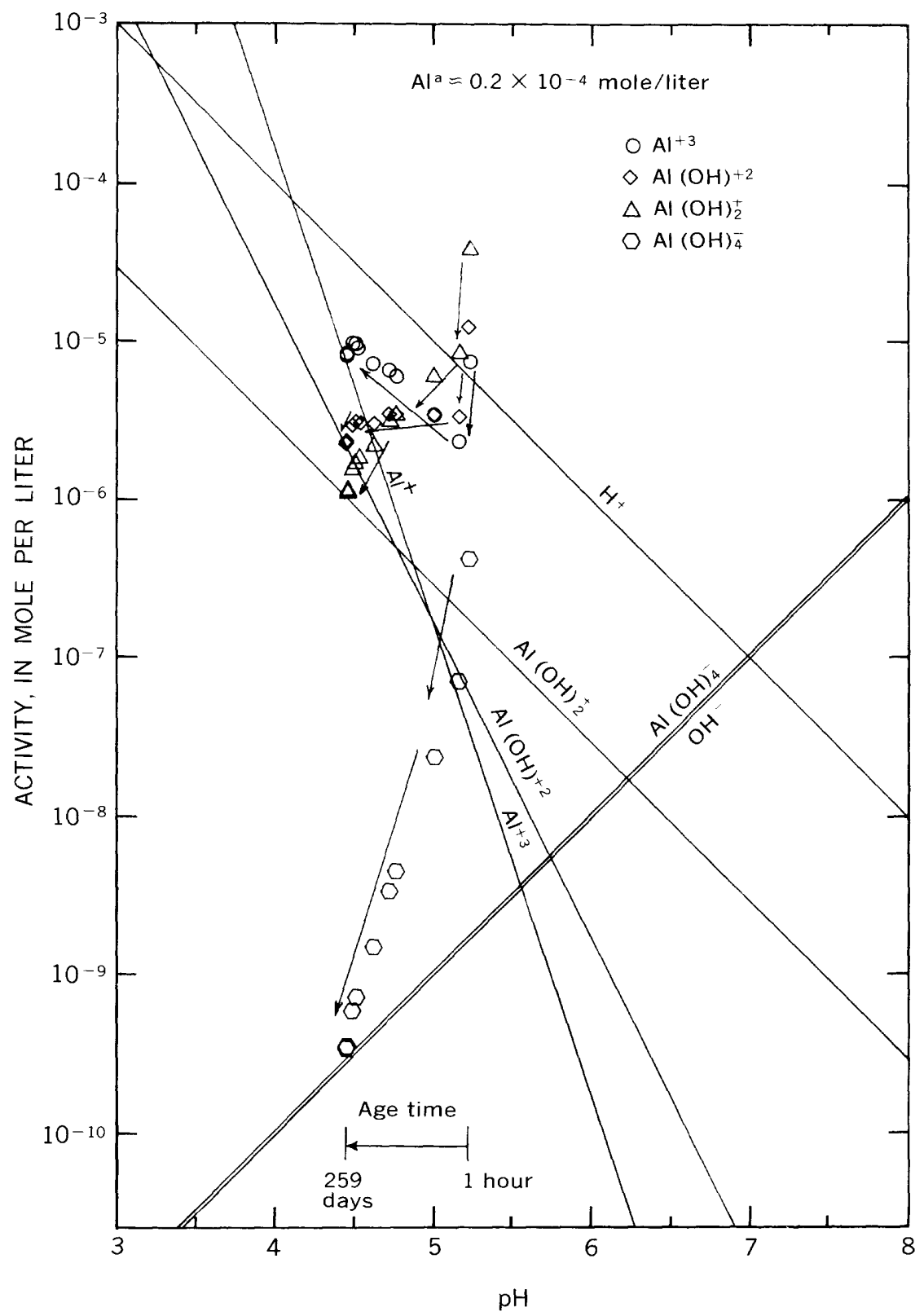

FIgURE 10.-Aging time effect on activity of monomeric species as a function of $\mathrm{pH}$ for solution $\mathrm{H}$. 


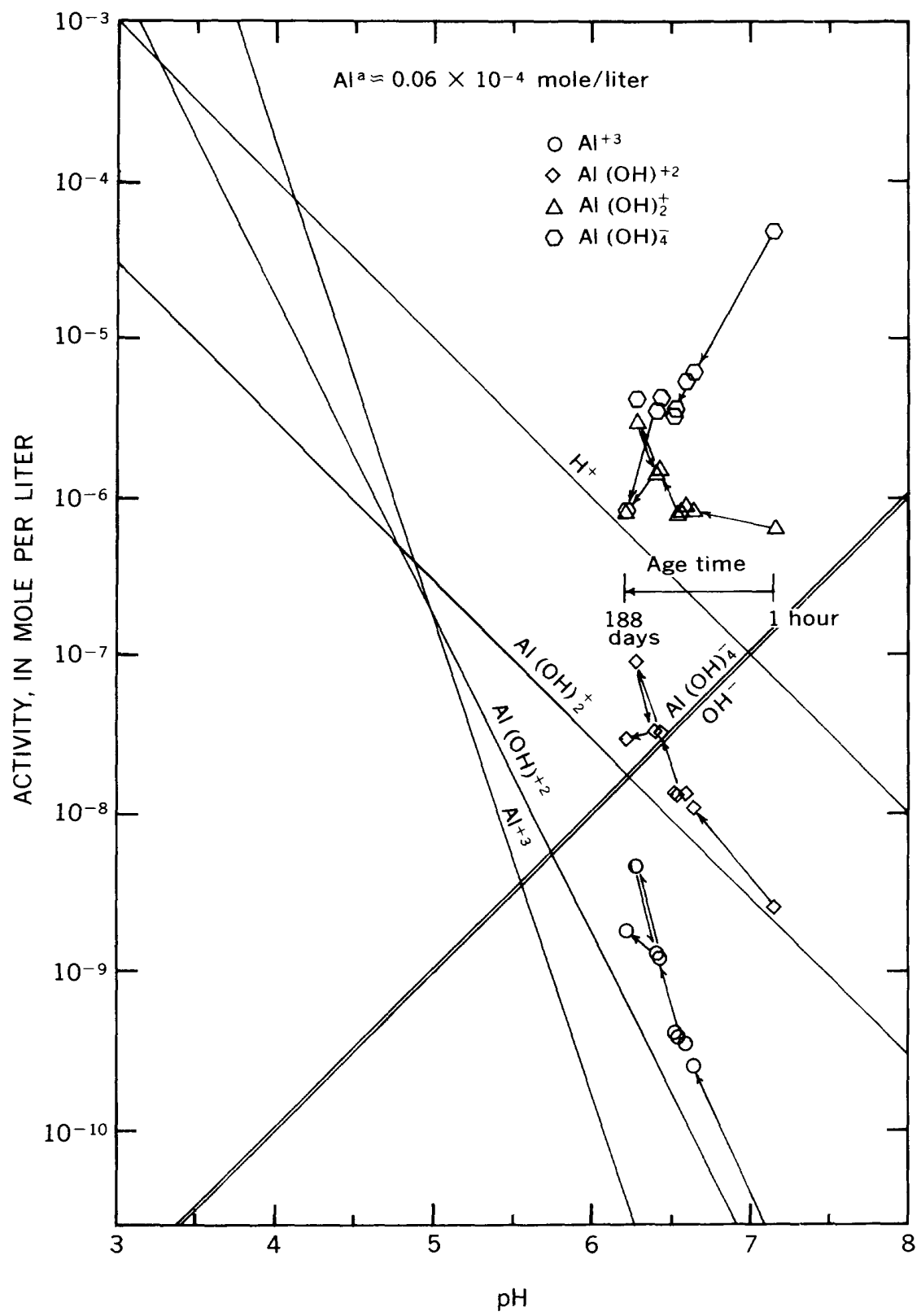

Figure 11.-Aging time effect on activity of monomeric species as a function of $\mathrm{pH}$ for solution J. 
with age. The $\mathrm{pH}$ of the solution, however, changed during aging, finally attaining a value that represents equilibrium with gibbsite having the free energy shown in table 3. At intermediate aging times $\mathrm{Al}^{\mathrm{a}}$ concentration is greater than it should be if solid, $\mathrm{Al}$, and the observed $\mathrm{pH}$ were in equilibrium. Further, all major adjustments of the system have to do with $\mathrm{pH}, \mathrm{Al}^{b}$, and $\mathrm{Al}^{\text {c }}$. Changes in monomeric species' activities merely reflect an essentially instantaneous adjustment of these activities to changing $\mathrm{pH}$, with an increase in proportion of $\mathrm{Al}^{+3}$ to hydroxylated forms as $\mathrm{pH}$ decreases.

\section{CHARACTERISTICS OF Al ${ }^{\mathrm{b}}$ AND Al}

Figures 12 through 18 have been constructed to show clearly progress of the amounts of $\mathrm{Al}^{\mathrm{b}}, \mathrm{Al}^{\mathrm{c}}$, and $\mathrm{Al}^{\mathrm{b}+\mathrm{c}}$ with time and $\mathrm{pH}$. Darkened points are for old solutions aged 1-3 years. Since $\mathrm{Al}^{\mathrm{c}}$ appears to be a solid material it is actually incorrect to think of $\mathrm{Al}^{\mathrm{c}}$ in terms of concentration "in solution." However, such a designation is convenient and helpful in showing the amount of solid species produced and in following the system as a function of time. These curves of minus $\log$ concentration of $\mathrm{Al}^{\mathrm{b}}$ and $\mathrm{Al}^{c}$ versus $\mathrm{pH}$ with appropriate times indicated again show that $\mathrm{Al}^{\mathrm{b}}$ decreases in concentration with time and $\mathrm{Al}^{c}$ increases. As a corollary to corstant $\mathrm{Al}^{\mathrm{a}}$ it should be noted that $\mathrm{Al}^{\mathrm{b}+\mathrm{c}}$ concentration stays constant vith aging time. Equilibrium is reached in the systems when the $\mathrm{Al}^{c}$ and the $\mathrm{Al}^{\mathrm{b}+\mathrm{c}}$ lines reach the dotted line which indicates the amount of crystalline gibbsite that should be present at equilibrium as a function of $\mathrm{pH}$. It is noted that, after a few days' aging, the equilik rium $\mathrm{pH}$ for these systems can be accurately predicted by extrapolating the $\mathrm{Al}^{\mathrm{b}+\mathrm{c}}$ curve, which generally appears to be a straight line parallel to the $\mathrm{pH}$ axis, to its intersection with the dotted gibbsite concentration curve.

Form $\mathrm{Al}^{a}$ appears to be composed of monomeric species, an $\gamma$ its total concentration is approximately constant after about 23 hours' aging. Form $\mathrm{Al}$, from both analysis and aging data and from electron microscope observation, consists of crystalline solid (colloidal) particles, and its concentration increases as a function of aging time until equilibrium is achieved. Form $\mathrm{Al}^{\text {b }}$ is present in all the solutions at 23 hours' aging and often in considerable concentrations. Its concentration then drops as a function of aging time until it finally disappears from solution when equilibrium is reached. It is obviously not permanently stable material and is ultimately converted to $\mathrm{Al}^{c}$. It reacts with ferron in the analytical procedure according to a first-crder rate law which suggests that all aluminum atoms in the material are individually reacting with ferron in a way that does not change as the $\mathrm{Al}^{\mathrm{b}}$ structures react and diminish in size in the procedure. Tl is would 


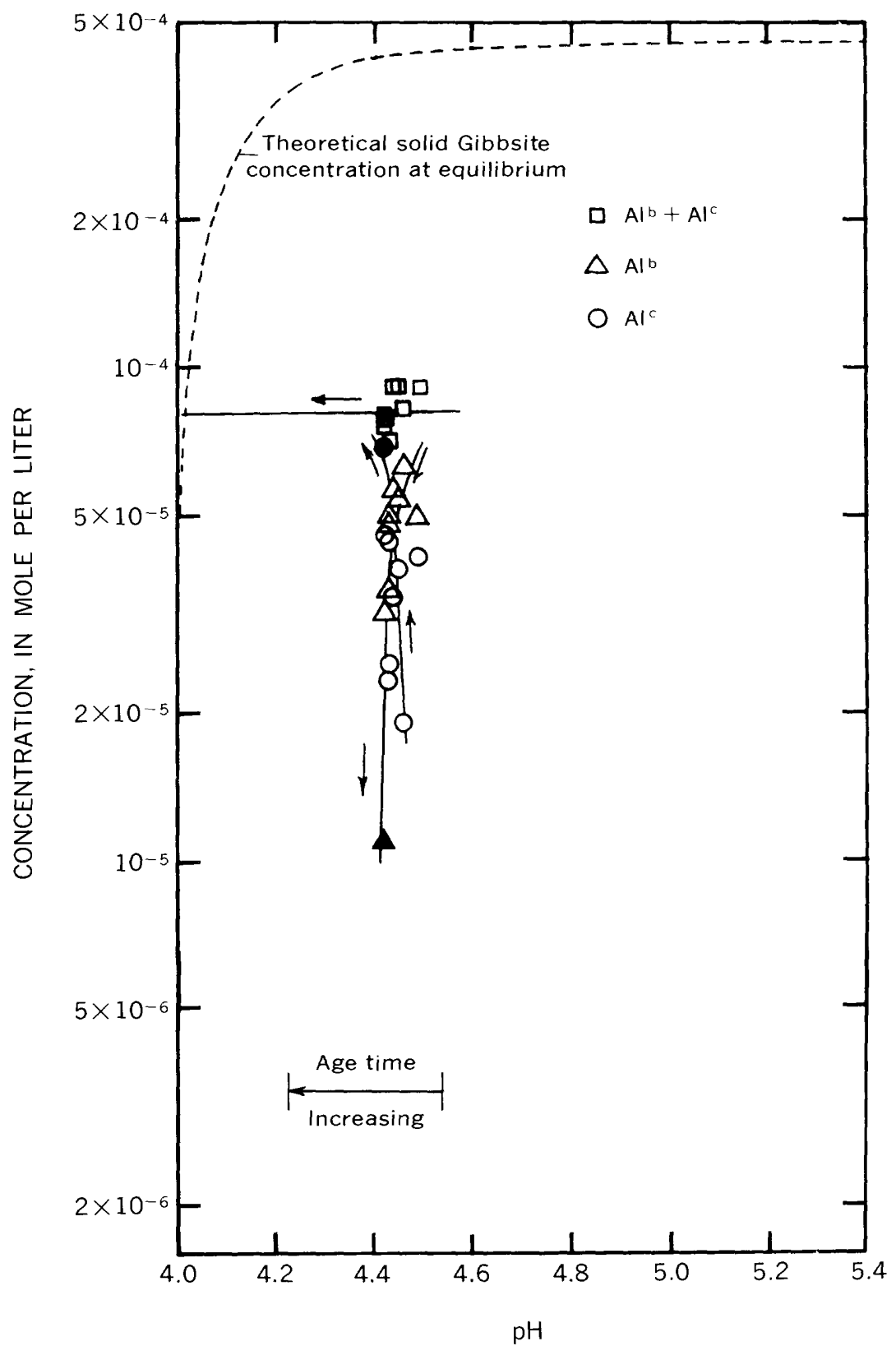

FIgURE 12.-Concentration of $\mathrm{Al}^{\mathrm{b}}$ and $\mathrm{Al} \mathrm{l}^{\mathrm{c}}$ as a function of $\mathrm{pH}$ and aging time for solution B. 


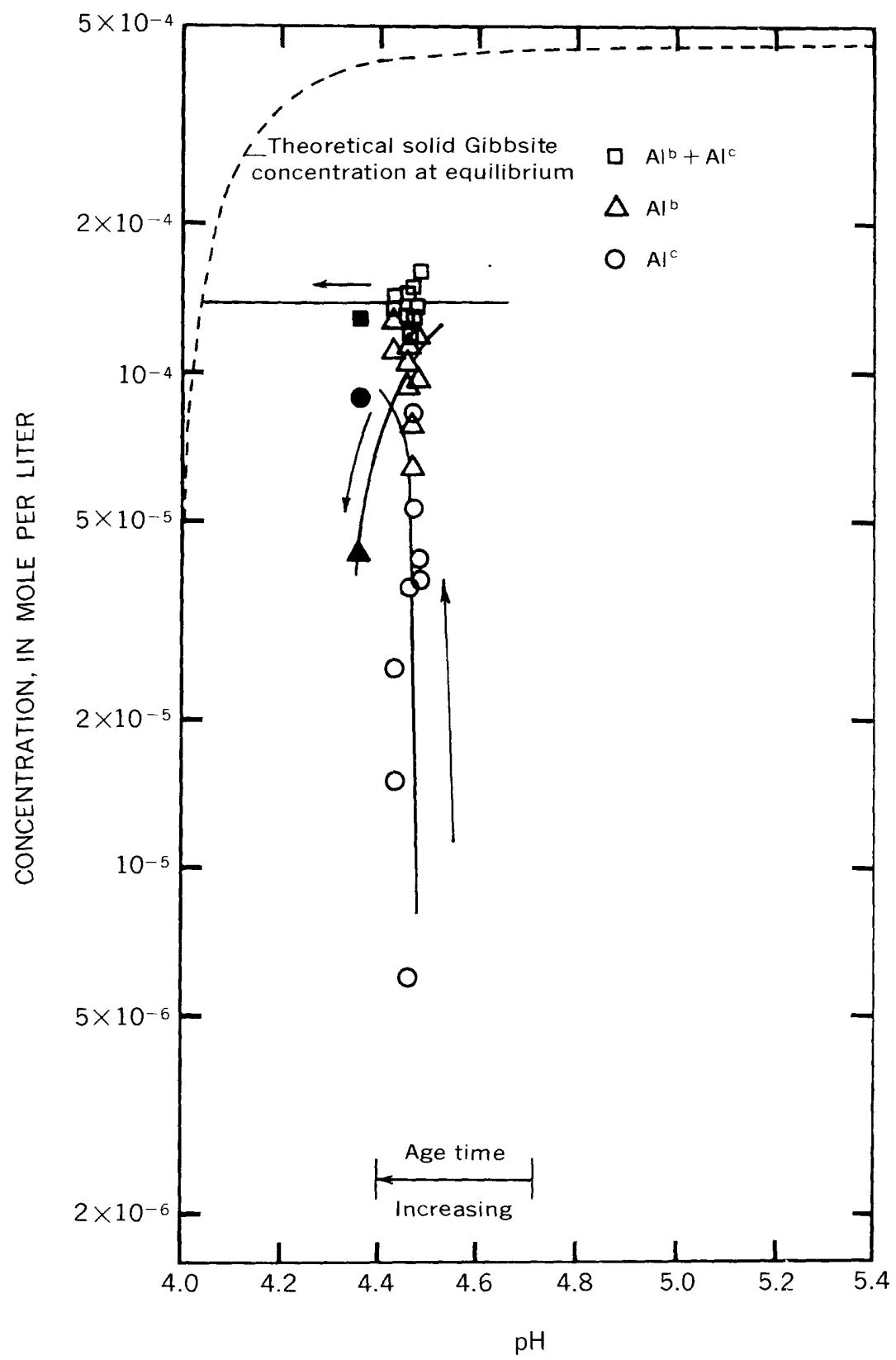

FIGURE 13.-Concentration of $\mathrm{Al}^{\mathrm{b}}$ and $\mathrm{Al}^{\mathrm{c}}$ as a function of $\mathrm{pH}$ and aging time for solution $\mathrm{C}$. 


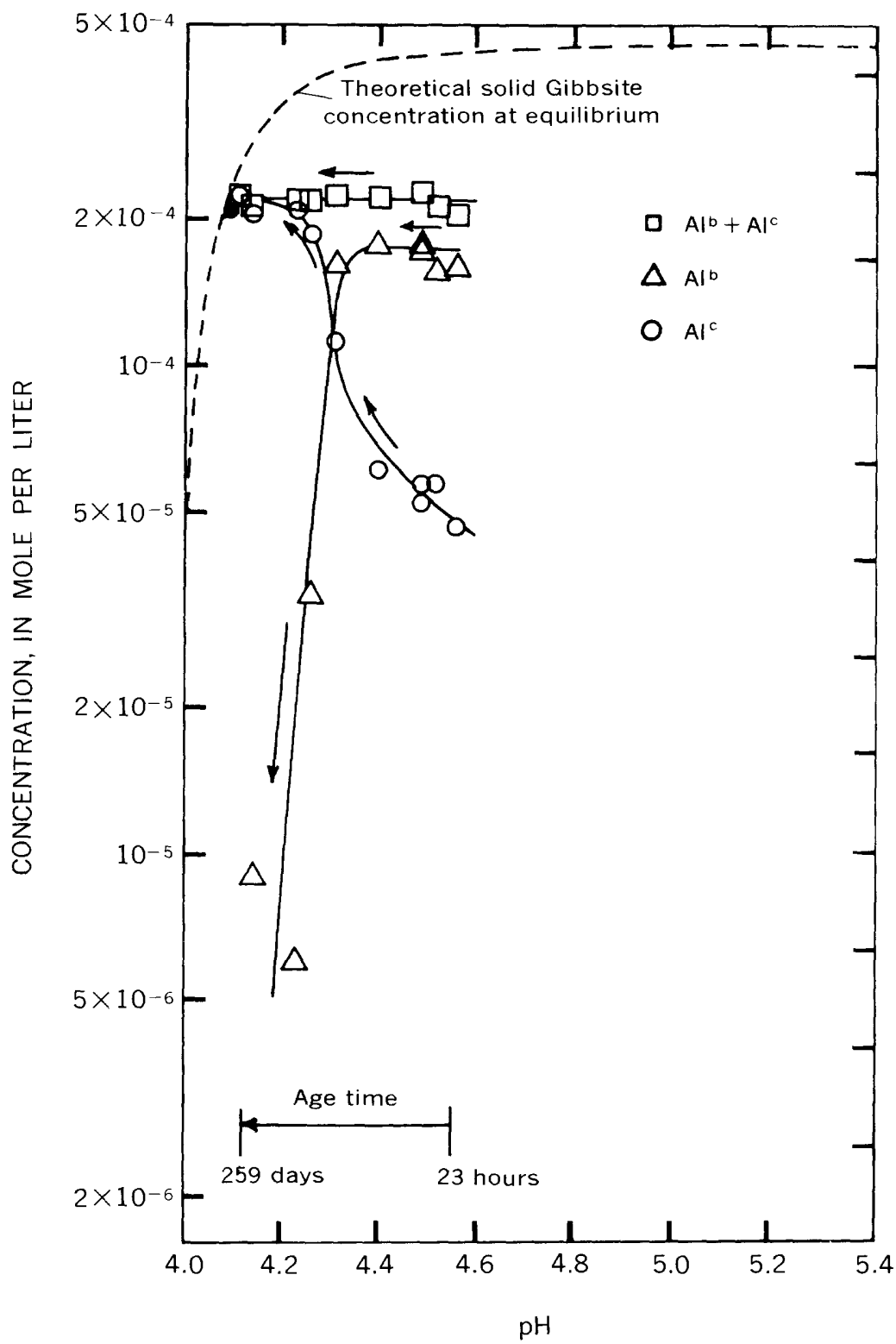

FIgURE 14.-Concentration of $\mathrm{Al}^{\mathrm{b}}$ and $\mathrm{Al}$ as a function of $\mathrm{pH}$ and aging time for solution $\mathrm{D}$. 


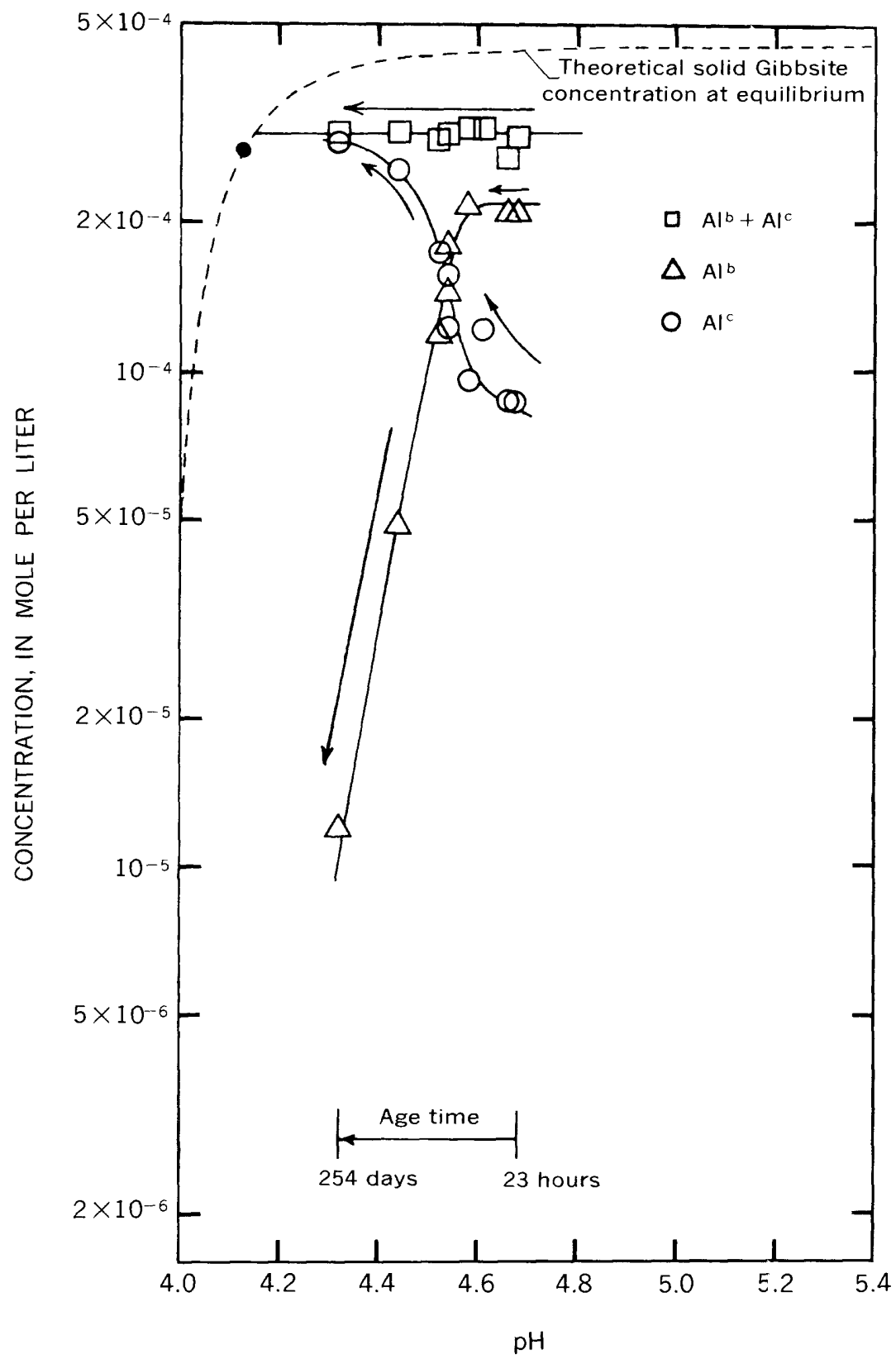

FIGURE 15. - Concentration of $\mathrm{Al}^{\mathrm{b}}$ and $\mathrm{Al}^{\mathrm{c}}$ as a function of $\mathrm{pH}$ and aring time for solution E. 


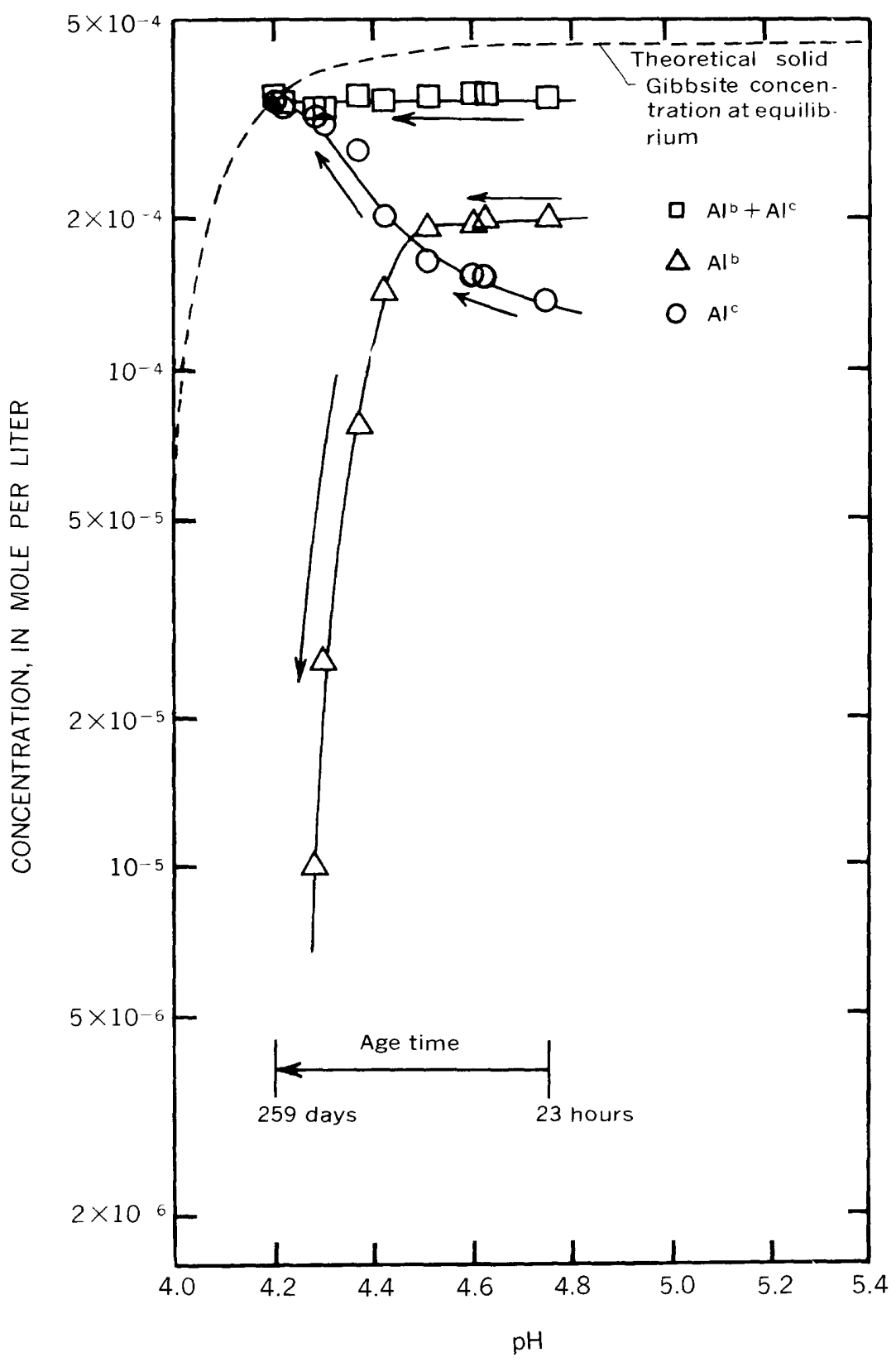

Figure 16.-Concentration of $\mathrm{Al}^{\mathrm{b}}$ and $\mathrm{Al}^{\mathrm{c}}$ as a function of $\mathrm{pH}$ and aging time for solution $\mathrm{F}$. 
D24 CHEMISTRY OF ALUMINUM IN NATURAL WATER

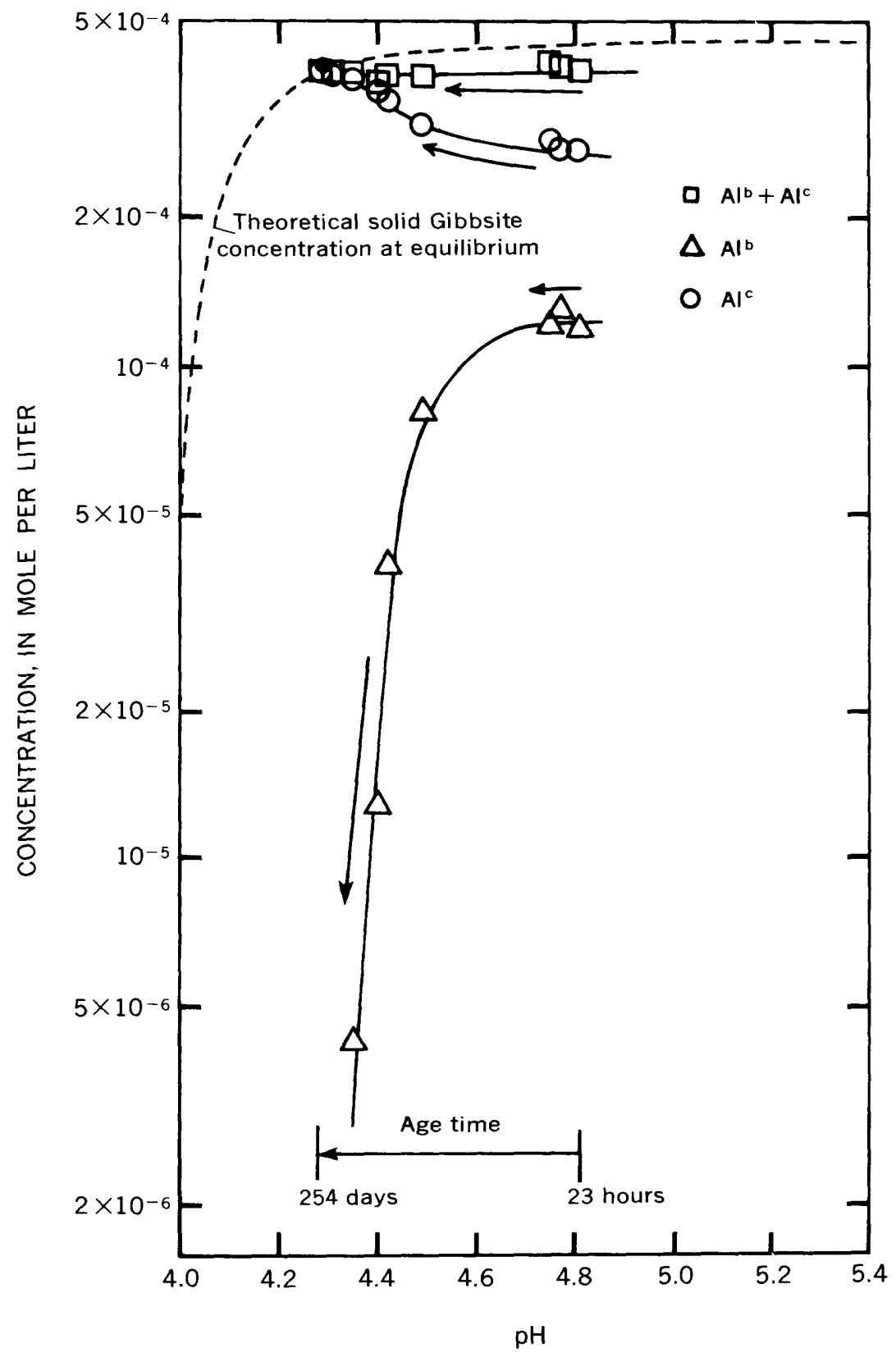

FIgURE 17.-Concentration of $\mathrm{Al}^{\mathrm{b}}$ and $\mathrm{Al}^{\mathrm{c}}$ as a function of $\mathrm{pH}$ and aging time for solution $\mathrm{G}$. 
AGING OF ALUMINUM HYDROXIDE COMPLEXES

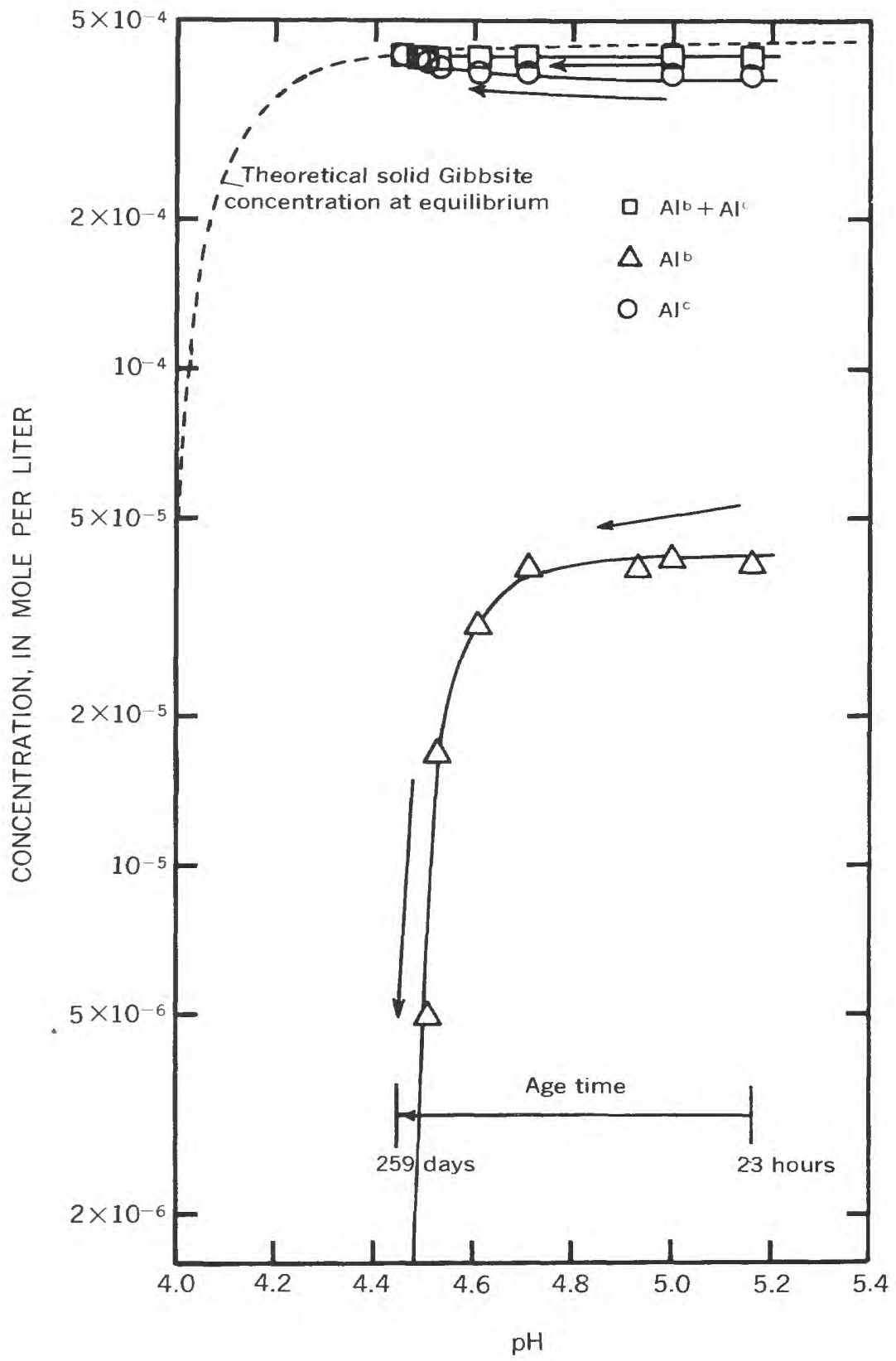

FIGURE 18.-Concentration of $\mathrm{Al}^{\mathrm{b}}$ and $\mathrm{Al}^{\mathrm{c}}$ as a function of $\mathrm{pH}$ and aging time for solution $\mathrm{H}$. 
indicate that the structures comprising $\mathrm{Al}^{\mathrm{b}}$ are not very large. One would expect large units to react at a rate proportional to the surface area exposed and to follow a rate law of order less than one. However, since it takes ferron a finite length of time to break down the $\mathrm{Al}^{\mathrm{b}}$ structures as compared with the time required to break down the $\mathrm{Al}^{\text {a }}$ structures, it would appear that the structures are rather strongly bound together. A structure of limited size containing 100-400 aluminum atoms in coalesced six-membered aluminum hydroxide rings, as suggested by either Hem and Roberson (1967) or Hsu and Bates (1964a, 1964b), would appear reasonable.

\section{ELECTRON MICROSCOPE OBSERVATIONS}

Particles of $\mathrm{Al}^{\mathrm{c}}$ are colloidal and can be observed under an electron microscope. Figures 19 through 21 show electron micrographs of $\mathrm{Al}^{\circ}$ from solutions F, G, and E. X-ray diffraction work has indicated that the hexagonal platelets are gibbsite (Schoen and Roberson, 1970). The solutions were aged about 2 years. Also shown on the micrographs are gold sol particles (small, dark spheres and tetrahedrons).

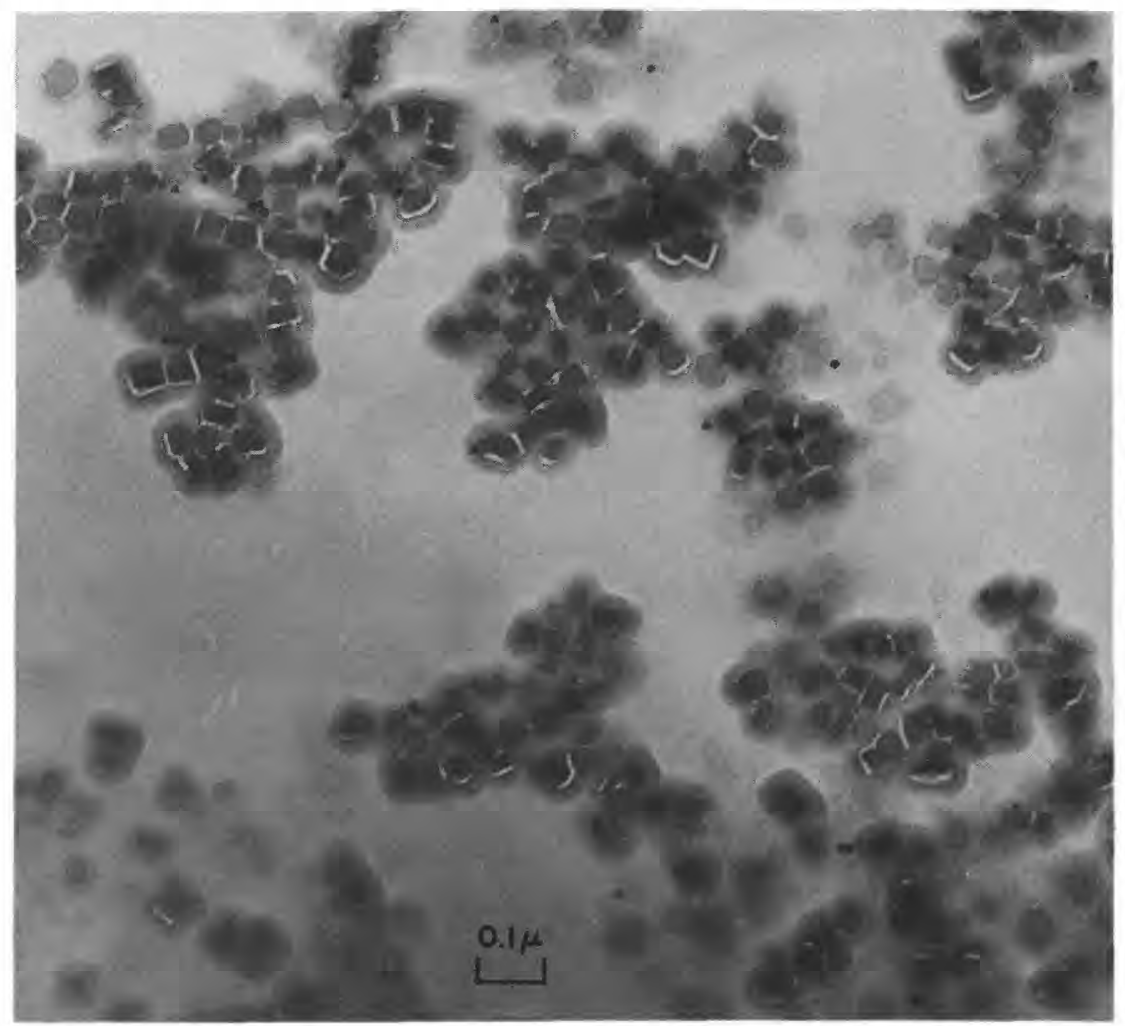

FIGURE 19.-Electron micrograph of microcrystalline gibbsite from solution $\mathrm{F}$ aged 2 years - with negative gold particles adsorbed. 


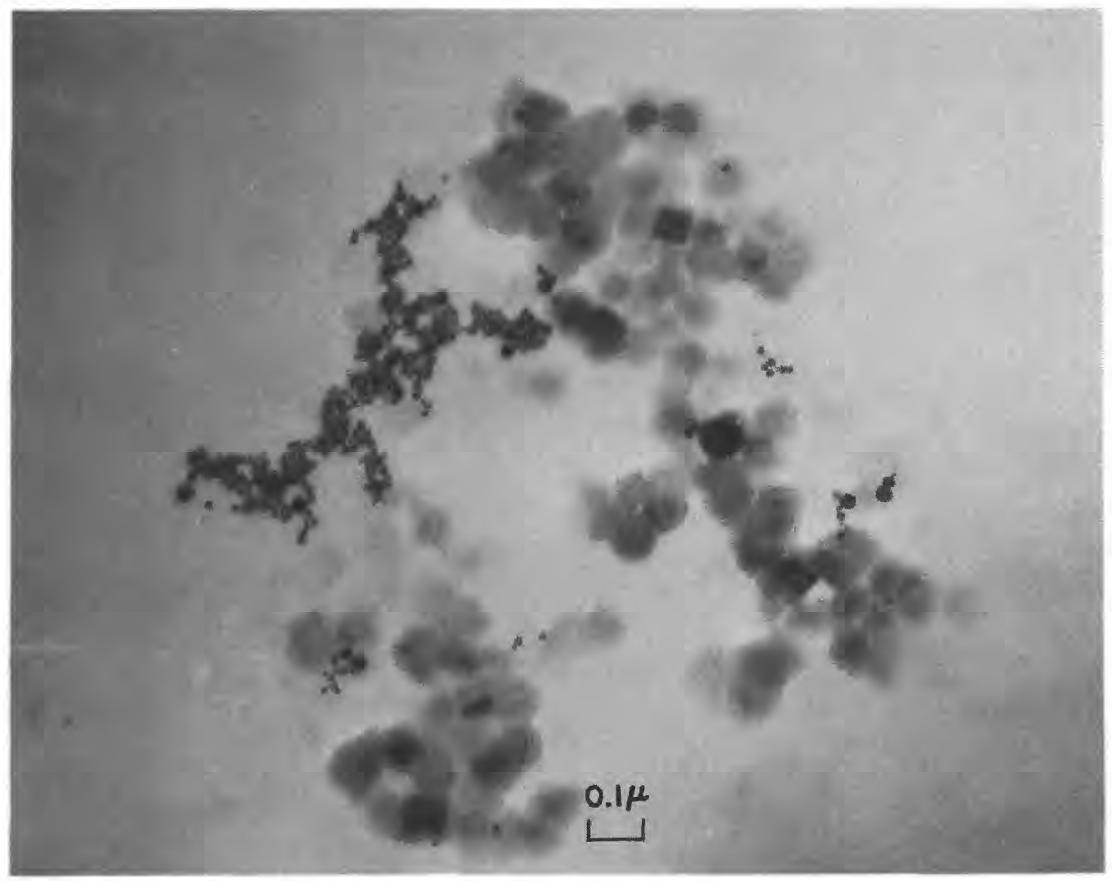

FIGURE 20.-Electron micrograph of microcrystalline gibbsite from solution $\mathrm{C}$ aged 2 years-with negative gold particles adsorbed.

Figure 22 shows an electron micrograph of particles from solution $\mathrm{J}_{2}$ which was $4.55 \times 10^{-3}$ molar in aluminum, had an ionic strength of about 0.1 , and had an $r$ value of 2.98. The solution was aged for about 2 months. The figure shows much of the detail of the particles, such as their typical crystalline shape and imperfections. The gold sol particles as prepared in this work are negatively charged (Thiessen, $1942,1947)$. It is interesting to note that these particles tend to adsorb on edges, corners, and imperfection points of the gibbsite crystals, particularly at the last two types of sites. The suggestion is, then, that corners and imperfection points are the most highly positive sites on the gibbsite surface.

The electron micrograph of the gibbsite of solution $\mathrm{F}$ is of particular interest since it apparently shows edges (rectangular shapes) as well as faces and indicates the relative thickness of the particles. Also, it can be seen that the particles appeared layered much in the manner of microscopic mica particles. The electron micrograph of material from solution $\mathrm{C}$ indicates that microcrystalline gibbsite is ultimately formed even if $r_{n}$ value is as low as 0.94 and $\mathrm{pH}$ is near 4 . 


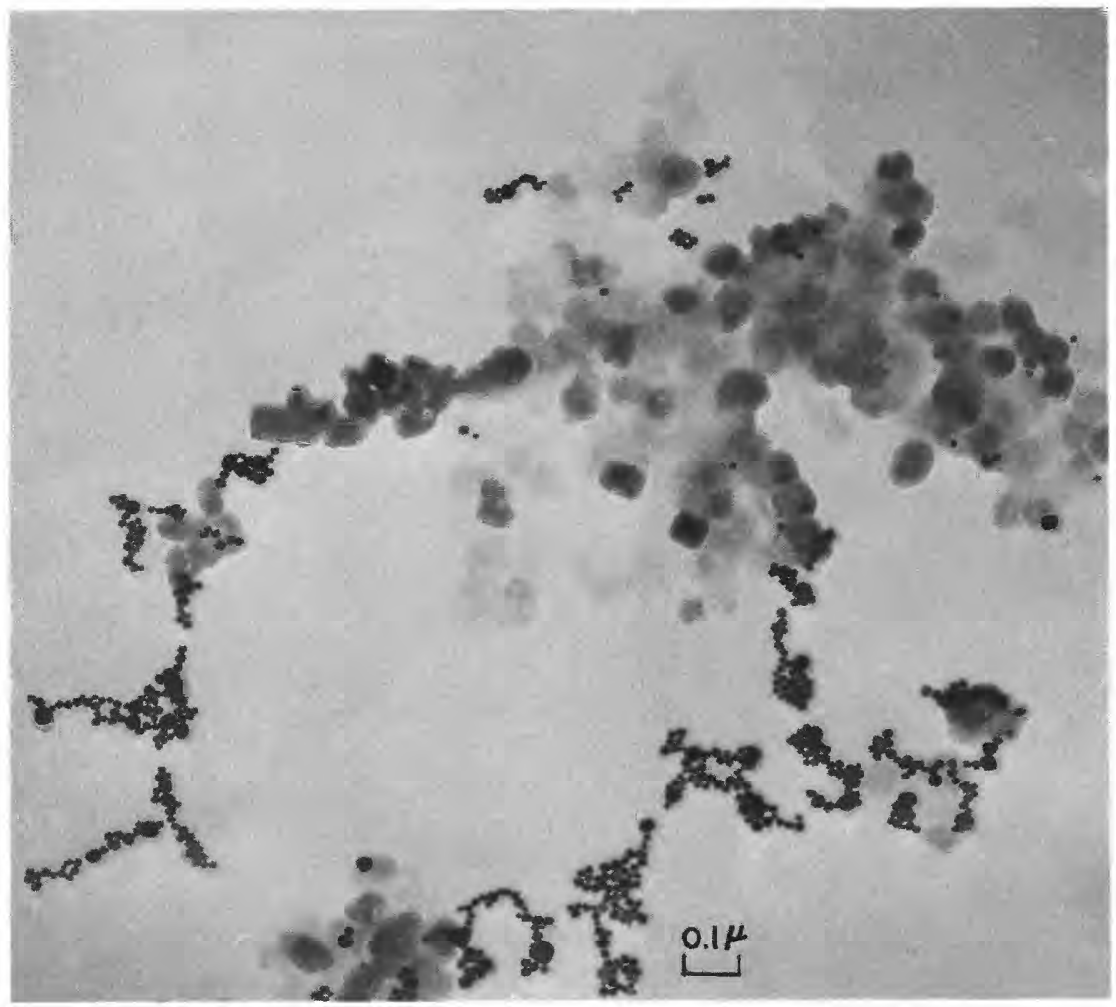

FIGURE 21.-Electron micrograph of microcrystalline gibbsite particles from solution E aged 2 years-with negative gold particles adsorbed.

Thus, the electron micrographs show conclusively that colloidal material is formed in the aging study solutions. Further, this material appears to be microcrystalline gibbsite.

\section{EFFECT OF RATE OF ADDITION OF BASE ON Al}

In preparing the experimental aging solutions the two stock aluminum solutions, 1 and 3 , which were both distinctly acid, were mixed together first, and the basic solution 2 was then added in the amount desired. An experiment was performed to determine whether the rate at which the base was added would influence the composition of the aluminum species in the final mixture. Four replicates of solution $\mathrm{H}$ were prepared, which differed only in the rate at which solution 2 was added to the mixture. One solution was prepared by very rapid addition requiring only 10 seconds. The other three were made by slower addition of the basic solution. The longest period of addition with mixing was 91 minutes. 


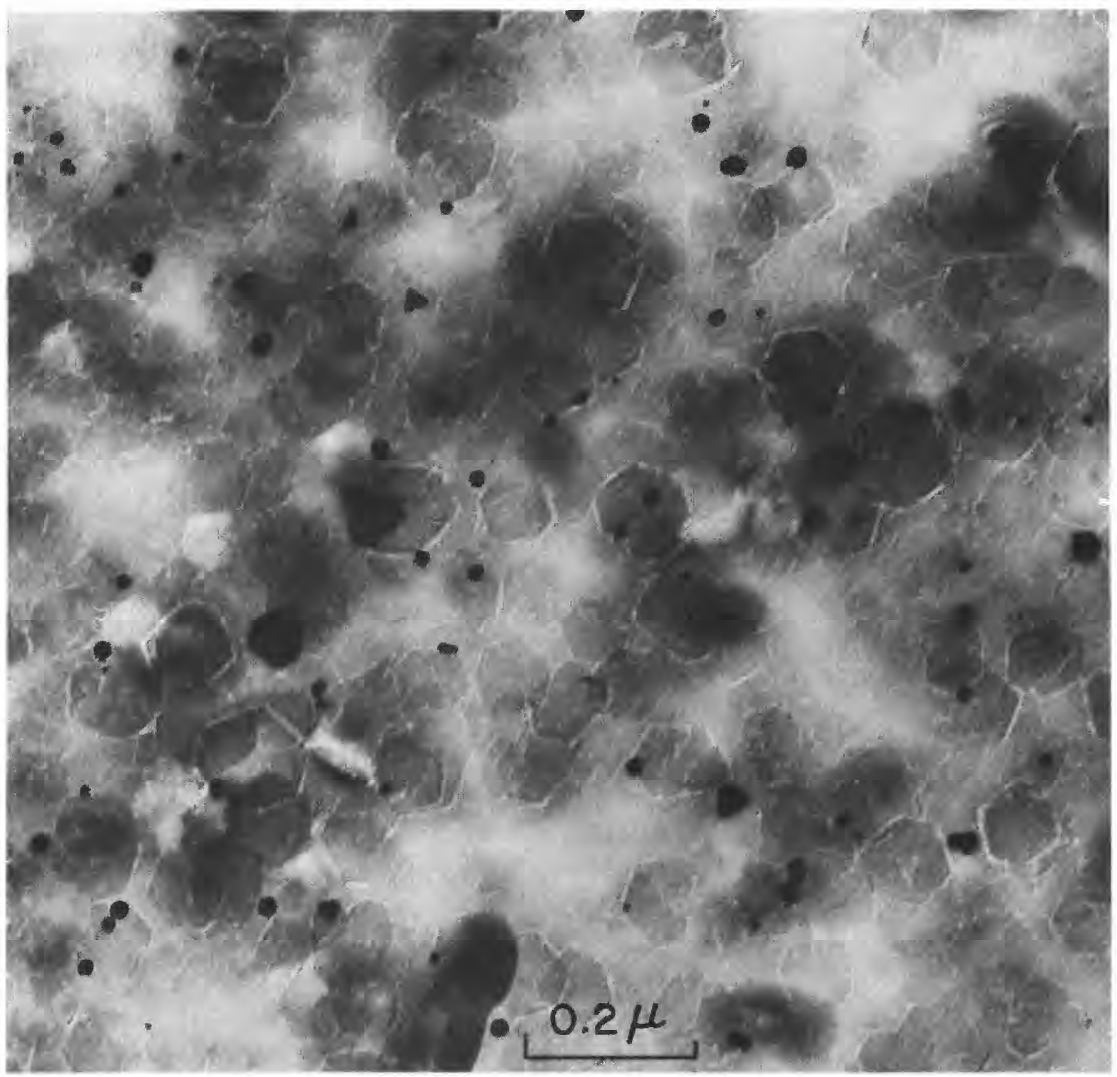

FIGURE 22.-Electron micrograph of microcrystalline gibbsite from solution $\mathbf{J}_{2}$ aged about 2 months-with negative gold particles adsorbed.

As figures 23 and 24 show, the four solutions did display significant differences. Figure 23 represents the results of the aluminum determinations. The common intercept of all the curves on the $y$ axis indicates the concentration of $\mathrm{Al}^{\mathrm{a}}$ was the same in all solutions and was evidently independent of the manner of preparation. However, the amount of $\mathrm{Al}^{\mathrm{b}}$, the fraction reacting during the first 100 minutes or so, is obviously greater in the solutions prepared by slower addition of base. A more easily interpreted representation of $\mathrm{Al}^{\mathrm{b}}$ concentrations is given in figure 24 , where the $\mathrm{Al}^{\mathrm{b}}$ concentrations at time zero can be seen to range from about $10^{-4.25}$ to $10^{-3.75}$. The higher $\mathrm{Al}^{\mathrm{b}}$ concentrations were accompanied by higher $\mathrm{pH}$ values.

All these solutions were aged for 7 days before the aluminum determinations were made. 


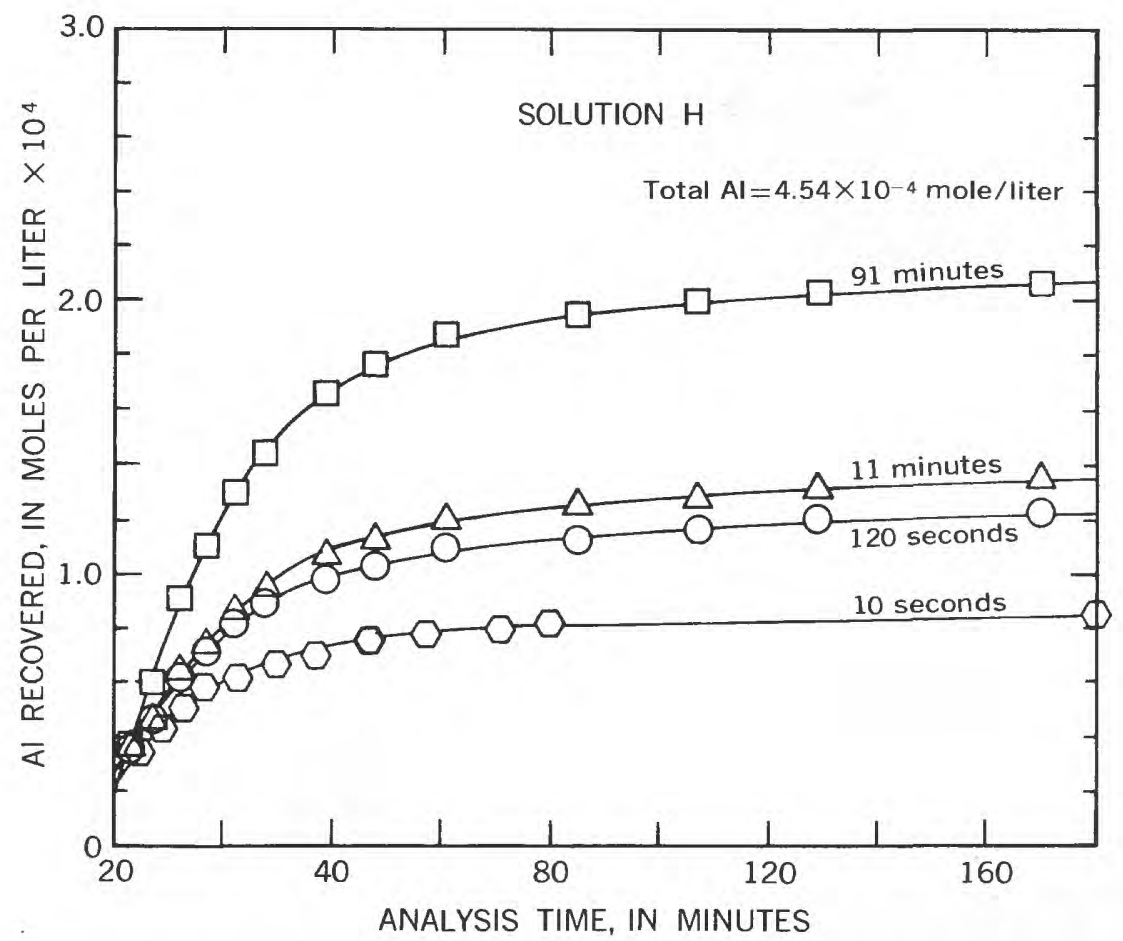

FIGURE 23.-Effect of length of time of adding base in preparing solutions on amount of $\mathrm{Al}^{\mathrm{b}}$ formed-aluminum recovered as a function of analysis time.

In general the results of this experiment show that the more slowly the base is added the farther away from equilibrium the mixture is when the aging period begins. The solutions where addition of base was made very slowly have the highest concentration of $\mathrm{Al}^{\mathrm{b}}$, produced at the expense of $\mathrm{Al}^{\mathrm{c}}$. For a particular $r_{n}$ value $\mathrm{Al}^{\mathrm{a}}$ is constant and independent of rate of base addition. Also, $\mathrm{pH}$ at the end of 1 week's aging is higher.

Rapid addition promotes formation of solid $\mathrm{Al}(\mathrm{OH})_{3}$ particles, possibly originally of a partly amorphous character. These particles appear to soon start organizing themselves into crystalline form (gibbsite under our experimental conditions). Slow addition gives less opportunity for local excess of base and formation of amorphous solid $\mathrm{Al}(\mathrm{OH})_{3}$. With slower addition of base, more monomeric and polynuclear species are initially formed. The monomeric species very rapidly convert to polynuclear microparticles or macroions in roughly the manner outlined by Hem and Roberson (1967). 


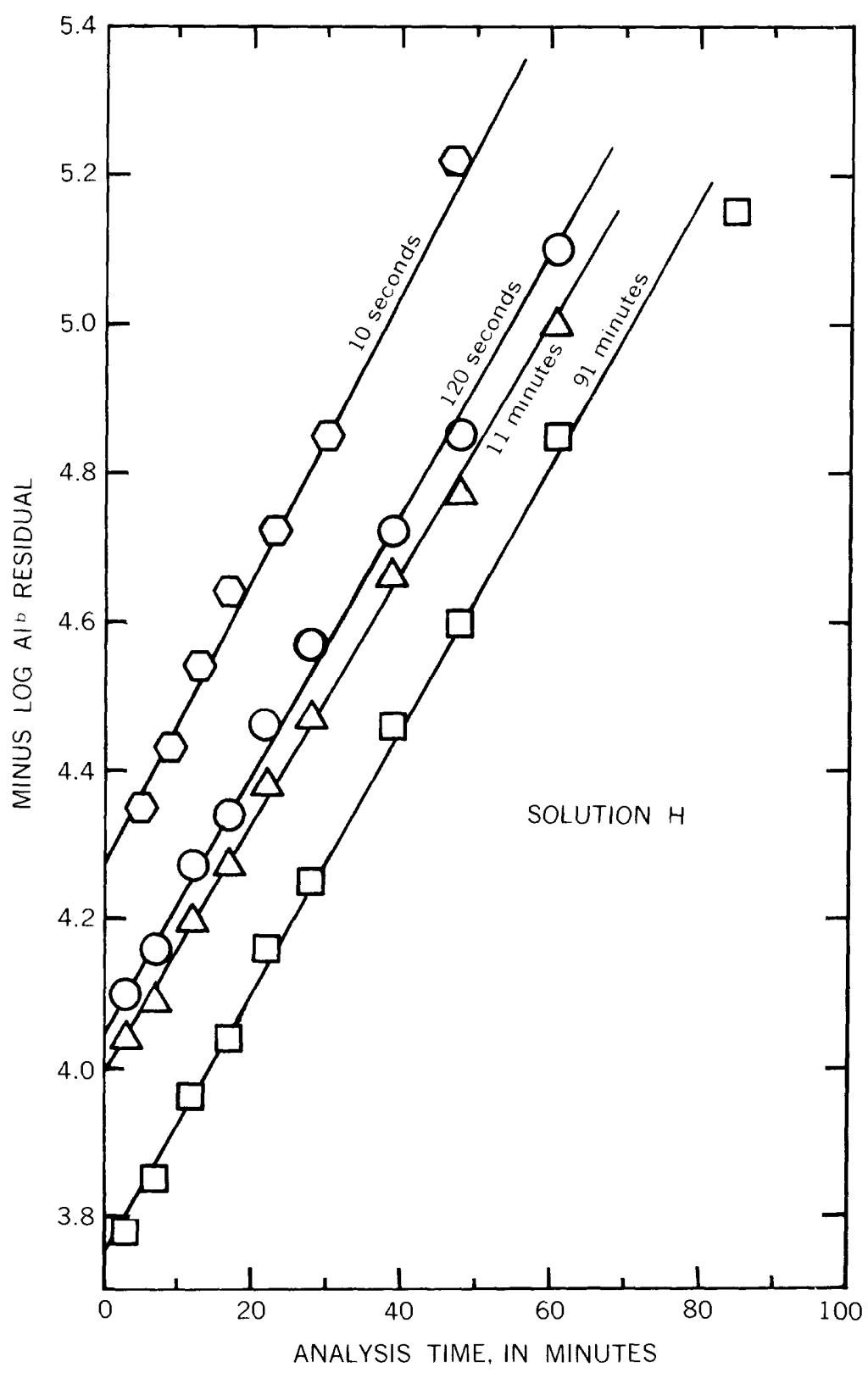

FrguRE 24.-First-order rate plot of $\mathrm{Al}^{\mathrm{b}}$ data from figure 23. 


\section{APPROACH OF SOLUTIONS TO EQUILIBRIUM}

The aging studies show that the amount of $\mathrm{Al}^{\text {a }}$ stays nearly constant after 1 day even though $\mathrm{pH}$ drops and that consentration of $\mathrm{Al}^{\mathrm{b}}$ decreases as $\mathrm{Al}^{\mathrm{c}}$ increases. Meanwhile, activities of monomeric species, as $\mathrm{Al}^{+3}$ and $\mathrm{Al}(\mathrm{OH})^{+2}$, adjust themselves accorc'ing to whatever $\mathrm{pH}$ change occurs in the system. It appears that individual $\mathrm{Al}_{x} \mathrm{~b}(\mathrm{OH})_{n x}+y$ particles must grow by combining witr each other accompanied with the "splitting out" of protons from combined water molecules. The relation between the monomeric species and the $\mathrm{pH}$ of the solution can be summed up in the equation (obtained by combining eq. 1-4)

$$
\mathrm{Al}^{+3}+\mathrm{Al}(\mathrm{OH})^{+2}+\mathrm{Al}(\mathrm{OH})_{2}{ }^{+}+\mathrm{Al}(\mathrm{OH})_{4}^{-}+5 \mathrm{H}_{2} \mathrm{O} \underset{4 \mathrm{Al}(\mathrm{OH})_{3}+5 \mathrm{H}^{+} .}{\rightleftarrows}
$$

The $\mathrm{Al}_{x}(\mathrm{OH})_{n x}{ }^{+y}$ intermediates are, of course, left out of the above equation because they are not of thermodynamic significance, disappearing from solution before equilibrium is attained.

The existence and distributions of activities of monomeric species of aluminum such as those on the left side of equation 8 seem to fit reasonably well at the equilibrium conditions attained after long aging. The possibility of dimeric or other small forms of aluminum hydroxide complexes is not ruled out by this equilibrium. Hem and Roberson (1967, p. 33) studied the kinetics of dissoluticn in acid of aluminum hydroxide species prepared in the same way as the ones described here. The kinetic behavior of hydroxide present in bridging positions was shown to differ sharply from that assignable to monomeric or unbridged positions. The studies of Hem and Roberson indicated that essentially all structural (bridging) hydroxide is associated with polymerized forms, or the equivalent of what is termed $\mathrm{Al}^{\mathrm{b}}$ and $\mathrm{Al}^{\mathrm{c}}$ in this report. Essentially no bridging hydroxide was left over to be assigned to $\mathrm{Al}^{\mathrm{a}}$.

It seems logical to conclude that $\mathrm{Al}^{a}$ consists of monomeric aluminum hydroxide complexes with negligible amounts of dimers, such as $\mathrm{Al}_{2}(\mathrm{OH})_{2}{ }^{+4}$, trimers, tetramers, or higher products of polymerization. Formation of polymers requires the initial step of forming a double hydroxide bridge between two monomers. This step appears to require an energy input because it does not occur in these solutions at a significant rate after the very early stages of the aging process $\left(\mathrm{Al}^{a}\right.$ remains nearly constant).

\section{KINETICS AND STRUCTURE OF NONEQUILIBRIUM SPECIES}

The procedure used here for determining the amount of $\mathrm{Al}^{\mathrm{b}}$ that is present during aging is based on the distinctive kinetics of this fraction of the aluminum when participating in complexing reactions 
with ferron. In earlier studies by Hem and Roberson (1967) the kinetics of the reaction of aluminum hydroxide species with $\mathrm{H}^{+}$were used to identify the equivalents of $\mathrm{Al}^{\mathrm{b}}$ and $\mathrm{Al}^{\mathrm{c}}$. The structural or bridging hydroxide was the substance whose quantity was directly determined; the molar proportion of bridging hydroxide to aluminum in this kind of material is directly related to the size of polymeric units if the units are considered to be evolving toward crystalline gibbsite. In this process there are strict geometric constraints that such structures impose on the way individual aluminum ions can be bound into the unit.

The work of Hem and Roberson further demonstrated that after the first few days the hydroxide contained in polymerized forms of aluminum hydroxide was nearly all in bridging positions. One could possibly explain the behavior of the $\mathrm{Al}^{\mathrm{b}}$ toward ferron by postulating that the material is a poorly organized polymer of indefinite structure and size which contains many imperfections, perhaps missirg hydroxide bridges or nonbridging hydroxide present in random positions. A more logical explanation, however, would seem to bo that $\mathrm{Al}^{\mathrm{b}}$ represents reasonably well organized units having gibbsite structures, and containing only minor amounts of unbridged hydroxide, which differ from $\mathrm{Al}^{\mathrm{c}}$ units only in being smaller. This explanation would appear to be the better one in view of the experimental observations of Hem and Roberson, which appear to rule out any large proportion of nonbridging hydroxide in polymeric material.

The number of aluminum ions per $\mathrm{Al}^{\mathrm{b}}$ unit can be calculated if the gibbsite structural pattern is imposed and if the mole ratio of hydroxide to aluminum in the units is known. The relationship is expressed graphically in figure 25 . The simplest single ring structure $\mathrm{Al}_{6}(\mathrm{OH})_{12}{ }^{+6}$ (fig. 26) has six aluminum ions and a ratio of $\mathrm{OH}: \mathrm{Al}$ of 2.0 (fig. 25). By the time the ratio reaches 2.95 the structure contains about 600 aluminum ions bound in a system of coalesced rings. The process of increasing size of structure is shown in figure 27 .

The coalescing of structures as shown in figure 27 represents deprotonation of water molecules along edges of the units as the hydroxide double bridges are formed. It is to be expected that this process will affect the $\mathrm{pH}$ of the system, and therefore the amount of change in $\mathrm{H}^{+}$activity during aging should be a rather direct indication of the amount of polymerization that is taking place.

From data in table 1 showing the amount of $\mathrm{Al}^{\mathrm{b}}$ present at various times during aging and the $\mathrm{pH}$ measurements made at the same times, an insight into the limiting composition of $\mathrm{Al}^{\mathrm{b}}$ can be obtained. Data from the table are shown graphically in figure 28, where the negative $\log$ of residual concentration of $\mathrm{Al}^{\mathrm{b}}$ is the ordinate and aging 


\section{D34 CHEMISTRY OF ALUMINUM IN NATURAL WATER}

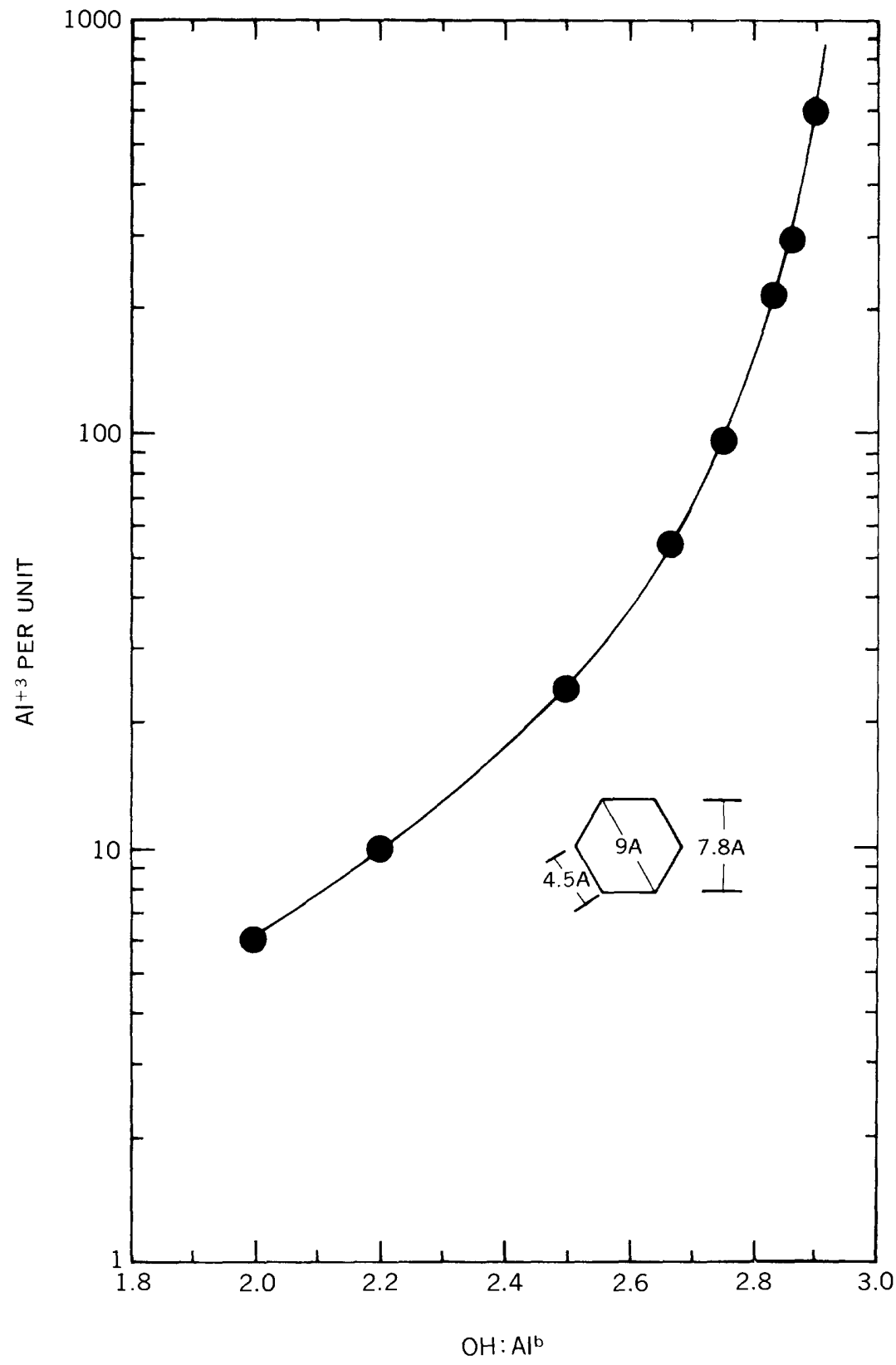

FIGURE 25.-Number of aluminum atoms as a function of the $\mathrm{OH}: \mathrm{Al}^{\mathrm{b}}$ ratio of the $\mathrm{Al}^{\mathrm{b}}$ particle. 


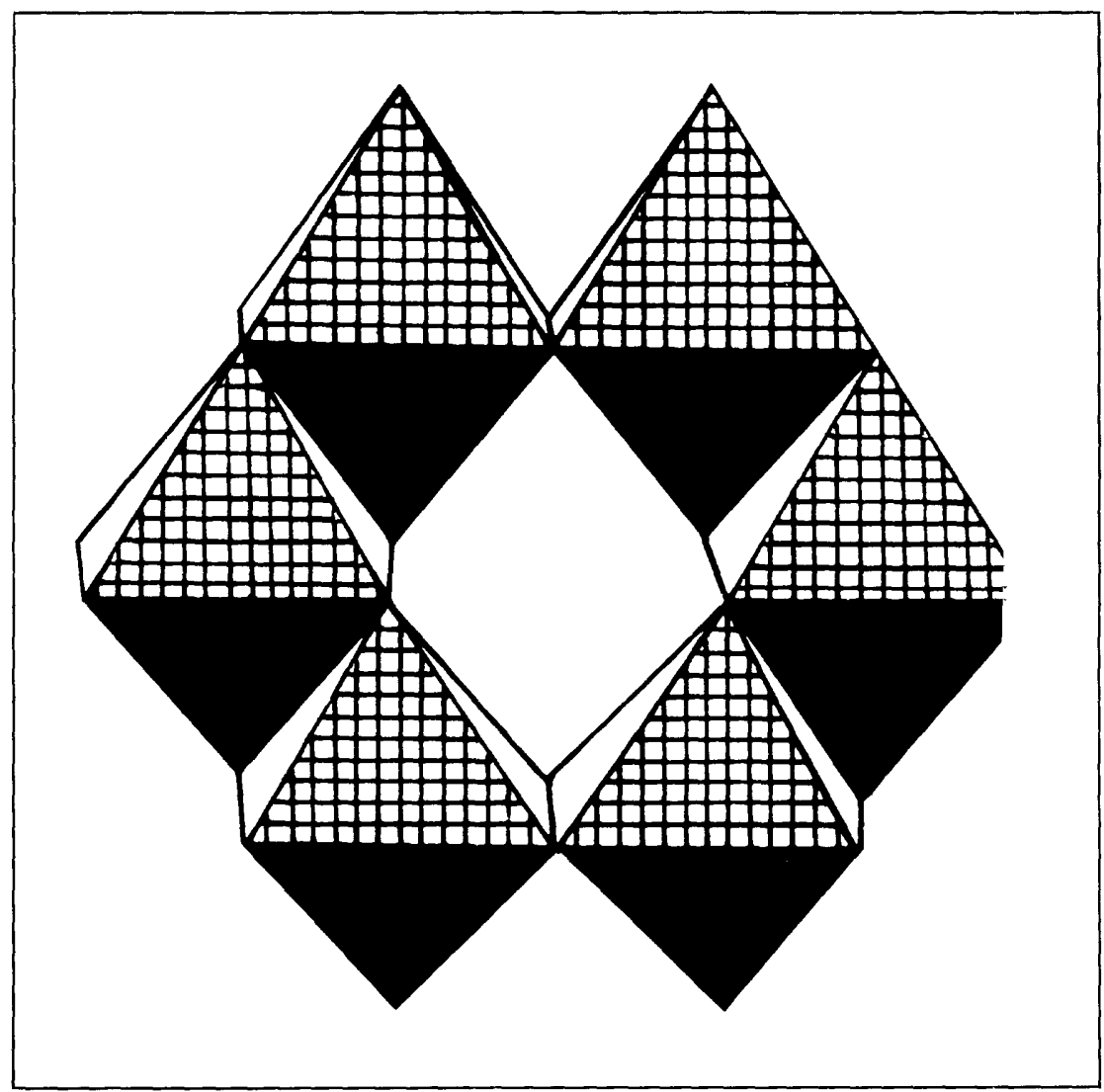

FIGURE 26.-Schematic representation of the ring structure formed by six al"minum hydroxide octahedra.

time in days is the abcissa. This is the form of a first-order kinetic plot, and it is of interest to note that four of the five solutions give approximate straight lines of equal slope for a long period of time (40-120 days). The data for shorter aging (up to 40 days) evidently represents the period in which small $\mathrm{Al}^{\mathrm{b}}$ units are coalescing but few particles are reaching a sufficient size to become Alc. During the period when the disappearance of $\mathrm{Al}^{\mathrm{b}}$ is more rapid, the reaction seems to obey a psuedo first-order mechanism. The straight-line parts of the rate curves in figure 28 represent the stage of polymerization where the polymeric units are reaching the upper limit of size for behavior as $\mathrm{Al}^{\mathrm{b}}$. Although the polymerization process would seem to be basically an encounter of two aluminum hydroxide units, and therefore possibly a second-order mechanism should govern, it is 


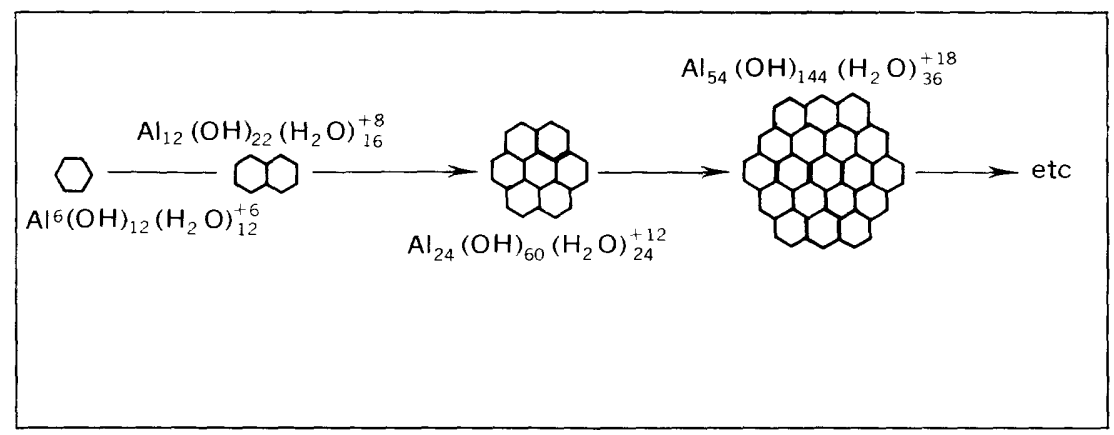

FIGURE 27.-Growth of polynuclear aluminum hydroxid@.

evident that the measurements of $\mathrm{Al}^{\mathrm{b}}$ give no indication of the number of units involved. A psuedo first-order behavior may therefore be within reason.

The decline in rate after 120 days probably is caused by lack of precision in measurements, as well as by the probability that the polymerization mechanism itself can operate at a relatively rapid rate only when $\mathrm{Al}^{\mathrm{b}}$ units are plentiful enough so that random encounters between units occur very frequently. As concentrations decrease the probability of encounters between units drops off rapidly.

As a further observation, it might be noted that the upper size limit of the $\mathrm{Al}^{\mathrm{b}}$ particles seems to be fairly definite and specific. At least the solutions acted very much alike after the point in the aging process where significant losses of $\mathrm{Al}^{\mathrm{b}}$ began to take place.

The aging data provide a means for calculating the average size of $\mathrm{Al}^{\mathrm{b}}$ units during the time these were being most rapidly transformed into $\mathrm{Al}{ }^{c}$. The concentration of $\mathrm{Al}^{\mathrm{b}}$ remaining in solution after 120 days' aging, subtracted from the amount present after about 40 days' aging, gives the quantity of aluminum converted from $\mathrm{Al}^{\mathrm{b}}$ to $\mathrm{Al}^{\mathrm{c}}$ during this period. The $\mathrm{Al}^{\mathrm{c}}$ is assumed to contain three hydroxide ions per aluminum ion. The change in $\mathrm{pH}$ of the solution during this aging period can be equated to the hydroxide demand of the $\mathrm{Al}^{\mathrm{b}}$ that was converted to $\mathrm{Al}^{c}$. When this is done the amcunt of hydroxide originally present in the converted $\mathrm{Al}^{\mathrm{b}}$ can readily be calculated, and the value of the mole ratio $\mathrm{OH}: \mathrm{Al}^{\mathrm{b}}$ determined for the material just before it became $\mathrm{Al}^{\mathrm{c}}$. The size of the units can then be estimated from figure 25.

For example, in solution $\mathrm{F}$ the decrease in concentration of $\mathrm{Al}^{\mathrm{b}}$ between the 46-day and 121-day observations was $0.68 \times 1.0^{-4}$ moles/ liter, and the $\mathrm{pH}$ change indicated a gain of $0.11 \times 10^{-4}$ moles/liter in concentration of $\mathrm{H}^{+}$during this period. The amount of hydroxide required for $0.68 \times 10^{-4}$ moles of $\mathrm{Al}(\mathrm{OH})_{3}$ is $2.04 \times 10^{-4}$ moles. The 


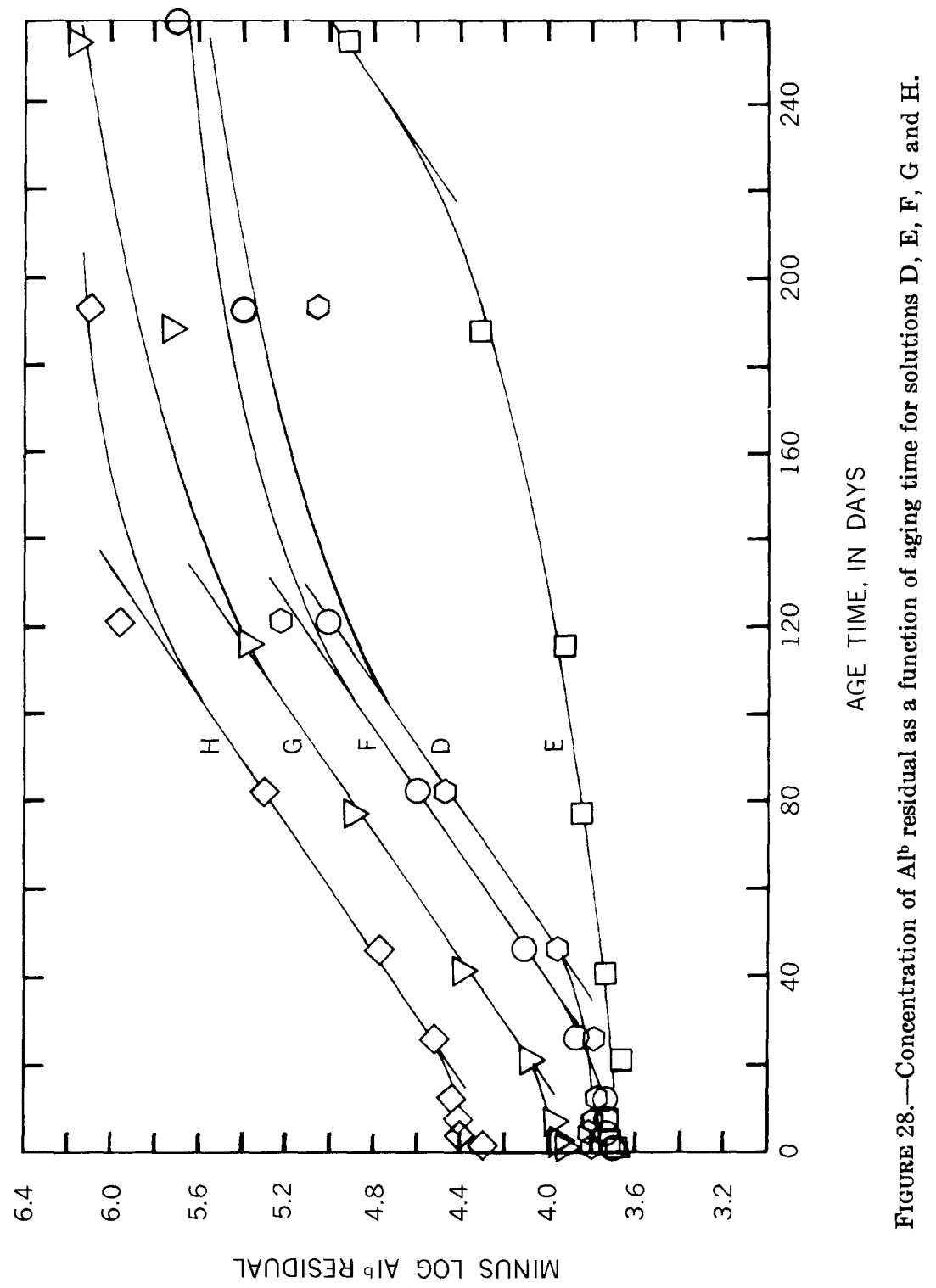


amount of hydroxide already present in the $\mathrm{Al}^{\mathrm{b}}$ lost was $(2.04-0.11) \times$ $10^{-4}$ or $1.93 \times 10^{-4}$ moles. The value of the molar ratio $\mathrm{OH}: \mathrm{Al}^{\mathrm{b}}$ is $1.93 / 0.68=2.84$. In this particular solution the total hydroxide tied up in monomeric $\mathrm{Al}^{\mathrm{a}}$ species was the same at 46 and at 121 days. This factor does need to be considered in some solutions, however, as the loss of hydroxide from monomers as the $\mathrm{pH}$ declines can be a significant source of hydroxide for incorporation into $\mathrm{Al}^{\mathrm{b}}$ structures.

From similar calculations the values of the ratio $\mathrm{OH}: \mathrm{Al}^{\mathrm{b}}$ at the upper size limit for this species was computed for solutions $\mathrm{D}-\mathrm{H}$. Results were as follows:

Solution

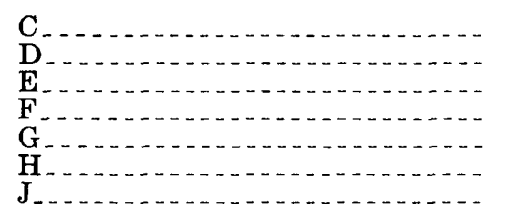

Molar ratio $\mathrm{OH}: \mathrm{Al}^{\mathrm{b}}$

2.81
2.87
2.83
2.84
2.80
2.73
2.86

Approximate formula $A l^{\mathrm{b}}$

$\mathrm{Al}_{200}(\mathrm{OH})_{562}{ }^{+38}$
$\mathrm{Al}_{400}(\mathrm{OH})_{1150}+50$
$\mathrm{Al}_{250}(\mathrm{OH})_{708}^{+42}$
$\mathrm{Al}_{300}(\mathrm{OH})_{853}^{+47}$
$\mathrm{Al}_{200}(\mathrm{OH})_{560^{+40}}^{+40}$
$\mathrm{Al}_{100}(\mathrm{OH})_{273}^{+27}$
$\mathrm{Al}_{350}(\mathrm{OH})_{1000}^{+50}$

In calculating the formula of $\mathrm{Al}^{\mathrm{b}}$ it is necessary to assume all the hydroxide that is found in the final structures is present in bridging positions. Prior experiments with forms of aluminum hydroxide equivalent to $\mathrm{Al}^{\mathrm{b}}$ and $\mathrm{Al}^{\mathrm{c}}$ described by Hem and Roberson (1967, p. 40) showed that after a few days' aging this assumptior is in accord with observed behavior.

This approach to calculating the formula of $\mathrm{Al}^{\mathrm{b}}$ suggests that the largest units have from 100 to 400 aluminum ions. A sirgle sheet of octahedra would thus be about 50 to $100 \mathrm{~A}$ (angstrom) in diameter (predicted from fig. 29). These data also tend to confirm the idea that the microcrystalline particles observed in the electron micrographs are gibbsite platelets.

EVALUATION OF AGING PROCESS BY NONEQUILIBRIUM THERMONYNAMICS

Chemical reactions that are slowly approaching a state of equilibrium can be studied by techniques of nonequilibrium thermodynamics. In this section the types of information that can be obtained in this way will be shown.

The relationship governing the final equilibrium in the aged solutions (eq. 8) can be used for calculation of reaction affinity. Results of this calculation are given in table 5. By utilizing norequilibrium thermodynamic concepts (van Rysselberghe, 1963; Morgan, 1967), it is possible to calculate advancement of the reaction, $\xi$, where $\xi$ is the ratio of the amount of some species that has reacted at a particular aging time to the total amount that will have reacted at equilibrium. The two species that react and are apparently "used up" as the aging 
TABLE 5.-Reaction affinities in kilocalories per mole, of solutions $B$ through $H$ in relation to age

\begin{tabular}{|c|c|c|c|c|c|c|c|}
\hline & B & $\mathrm{C}$ & D & E & F & G & $\mathrm{H}$ \\
\hline \multicolumn{8}{|l|}{ Hours } \\
\hline \multirow{4}{*}{$\begin{array}{l}23 \\
48 \\
96\end{array}$} & 7.0 & \multirow{3}{*}{6.6} & \multirow{3}{*}{$\begin{array}{l}9.2 \\
7.4\end{array}$} & \multirow{3}{*}{$\begin{array}{r}10.4 \\
8.0 \\
8.1\end{array}$} & \multirow{2}{*}{$\begin{array}{r}10.5 \\
8.2\end{array}$} & \multirow{3}{*}{$\begin{array}{r}11.6 \\
7.6 \\
7.0\end{array}$} & \multirow{2}{*}{$\begin{array}{r}12.8 \\
8.9\end{array}$} \\
\hline & \multirow{2}{*}{$\begin{array}{l}6.5 \\
7.3\end{array}$} & & & & & & \\
\hline & & & & & \multirow{4}{*}{$\begin{array}{l}6.5 \\
6.1 \\
4.8\end{array}$} & & \multirow{4}{*}{$\begin{array}{l}7.2 \\
4.7 \\
4.1\end{array}$} \\
\hline & $\mathcal{c}$ & \multirow{3}{*}{$\begin{array}{l}6.1 \\
6.2 \\
6.5\end{array}$} & \multirow{3}{*}{$\begin{array}{l}6.8 \\
6.1 \\
6.2\end{array}$} & $\mathrm{c}^{\circ}$ & & 58 & \\
\hline $\begin{array}{l}168 \ldots \ldots \\
288\end{array}$ & 6.6 & & & 6.2 & & 5.8 & \\
\hline 505 & $6 . \overline{9}$ & & & 6.1 & & 3.2 & \\
\hline $625 \ldots$ & $\ldots$ & 6.6 & \multirow[t]{2}{*}{$4 . \overline{8}$} & $\ldots$ & \multirow[t]{2}{*}{3.3} & ... & $2 . \overline{7}$ \\
\hline \multicolumn{6}{|l|}{ Days } & & \\
\hline 41 & 6.5 & \multirow{2}{*}{6.6} & \multirow{2}{*}{$3 . \overline{6}$} & 6.0 & \multirow{2}{*}{$\overline{2} . \overline{5}$} & 2.3 & \multirow{2}{*}{$\overline{1} . \overline{8}$} \\
\hline $46 \ldots$ & 6 & & & & & 10 & \\
\hline 82 & 6.5 & \multirow[t]{2}{*}{$\overrightarrow{6.9}$} & $2 . \overline{7}$ & 6.0 & 1.8 & 1.9 & 1.6 \\
\hline $116 \ldots \ldots$ & 6.5 & & \multirow{2}{*}{$2 . \overline{3}$} & 5.8 & \multirow{2}{*}{$1 . \overline{5}$} & 1.1 & \multirow{2}{*}{$\overline{1} . \overline{2}$} \\
\hline $\begin{array}{l}121 \ldots \ldots \\
188 \ldots \ldots\end{array}$ & 6.3 & $\overline{6} . \overline{6}$ & & 45 & & 3 & \\
\hline 193 & & \multirow[t]{2}{*}{6.6} &.$\overline{9}$ & $4 . J$ & .3 & .0 & .2 \\
\hline 254 & 6.3 & & & 2.6 & & .0 & \\
\hline _ & ... & 6.6 & .5 & $\ldots$ & .0 & $\ldots$ & .2 \\
\hline
\end{tabular}

process proceeds are $\mathrm{Al}^{\mathrm{b}}$ and $\mathrm{OH}^{-}$. Table 6 shows calculated $\xi_{\mathrm{Al}}{ }^{\mathrm{b}}$ values for solutions D, E, F, G and $\mathrm{H}$.

It should be noted that in all cases the amount of $\mathrm{Al}^{\mathrm{b}}$ did not change until a certain aging time had elapsed. For calculating $\xi_{\mathrm{A} 1^{\mathrm{b}}}$ which is the ratio of the $\mathrm{Al}^{\mathrm{b}}$ reacted at a particular aging time to total amount originally present, an average value for total $\mathrm{Al}^{b}$ noted was taken. From data of table 6 , the curves of figure 29 were constructed. This figure shows $\xi_{\mathrm{Al}}{ }^{\mathrm{b}}$ as a function of time. A tangent to a curve at any aging time is a measure of $d \xi / d t$ at that particular aging time. From

TABLE 6.-Advancement of the reaction $\left(\xi_{\mathrm{Al}} \mathrm{b}\right)$ values and $\mathrm{Al}$ b residual values of solutions in relation to age

$[\mathrm{A}]^{\mathrm{b}}$, residual, concentrations $\left.\times 10^{4}\right]$

\begin{tabular}{|c|c|c|c|c|c|c|c|c|c|c|}
\hline & \multicolumn{2}{|c|}{ D } & \multicolumn{2}{|c|}{$\mathbf{E}$} & \multicolumn{2}{|c|}{$\mathbf{F}$} & \multicolumn{2}{|c|}{ G } & \multicolumn{2}{|c|}{ H } \\
\hline & $\mathrm{Al}^{\mathrm{b}}$ & $\xi_{\mathrm{Al}} \mathrm{b}$ & $\mathrm{Al}^{\mathrm{b}}$ & $\xi_{\mathrm{A} \mathrm{I}^{\mathrm{b}}}$ & $\mathrm{Al}^{\mathrm{l}} \mathrm{b}$ & $\xi_{\mathrm{Al}} \mathrm{b}$ & $\mathrm{Al}^{\mathrm{b}}$ & $\xi_{\mathrm{A} \mathrm{I} \mathrm{b}}$ & $\mathrm{Al}^{\mathrm{b}}$ & $\xi_{\mathrm{A} \mid \mathrm{b}}$ \\
\hline \multicolumn{11}{|l|}{ Hours } \\
\hline $23 \ldots \ldots$ & 1.58 & 0.000 & 2.10 & 0.000 & 2.05 & 0.000 & 1.20 & 0.000 & 0.50 & 0.000 \\
\hline & 1.54 & $.00 \overline{0}$ & 2.00 & .000 & 1.86 & .000 & 1.15 & .000 & .40 & .000 \\
\hline $168 \ldots$ & $\begin{array}{l}1.62 \\
1.66\end{array}$ & $\begin{array}{l}.000 \\
.000\end{array}$ & 1.86 & .000 & $\begin{array}{l}1.86 \\
1.82\end{array}$ & $\begin{array}{l}.000 \\
.000\end{array}$ & 1.04 & .000 & $\begin{array}{l}.39 \\
.36\end{array}$ & .000 \\
\hline $\begin{array}{l}505 \\
625 \\
\end{array}$ & 1.63 & .000 & 2.14 & .000 & 1.35 & .289 & $.8 \overline{1}$ & .289 & $.3 \overline{0}$ & .268 \\
\hline Days & & & & & & & & & & \\
\hline $41 \ldots$ & & & 1.82 & .104 & $\cdots \overline{0}$ & $5 \overline{5}-\overline{1}$ & .40 & .649 & $\overline{7}$ & 585 \\
\hline 77 & 1.11 & .323 & 1075 & 286 & .78 & .590 & 13 & $-\overline{8} \overline{7}$ & .17 & .585 \\
\hline 116 & .34 & $.78 \overline{9}$ & 120 & & .26 & .863 & 043 & 962 & .05 & .878 \\
\hline 121 & .06 & .963 & & $-0=0$ & .10 & $.94 \overline{7}$ & .040 & . & .111 & .973 \\
\hline 198 &.$\overline{9}$ & .938 & .49 & .758 & $-\overline{0} \overline{4}$ & $\overline{9} \overline{7} \overline{8}$ & .019 & .983 & $-\overline{0} \overline{0}^{\overline{2}}$ &.$\overline{981}$ \\
\hline $\begin{array}{l}254 \\
259\end{array}$ & .02 & .987 & .12 & $.94 \overline{2}$ & .02 & 990 & .007 & .993 & .00̄ & 1.000 \\
\hline & & & & & & & & & & \\
\hline
\end{tabular}


these $d \xi / d t$ values plus the $\mathrm{Al}^{\mathrm{b}}$ concentrations at the same aging time, it is possible to estimate the order of the reactions over various discrete time intervals.

In general,

$$
-\frac{d x}{d t}=k x^{n}
$$

where $x$ is the concentration of some species (in our case $\mathrm{Al}^{\mathrm{b}}$ ), $t$ is time, $k$ is a constant, and $n$ is the order of the reaction relative to species $x$.

$$
\frac{d \xi}{d t}=\frac{d\left(\frac{x}{x(\text { total })}\right)}{d t} .
$$

Thus, for a time interval such as between 12 and 26 days' aging, values of $d \xi / d t$ and $x$ can be substituted in equation $9, k$ can be eliminated, and the value of $n$ can be determined. By this general procedure the data of table 7 were determined. Solution $\mathrm{E}$ was not included because of anomalies in the data for this solution. From the table it can be seen that the reaction involving the loss of $\mathrm{Al}^{\mathrm{b}}$ from solution is very close to the first order with respect to $\mathrm{Al}^{\mathrm{b}}$ over much of the aging time.

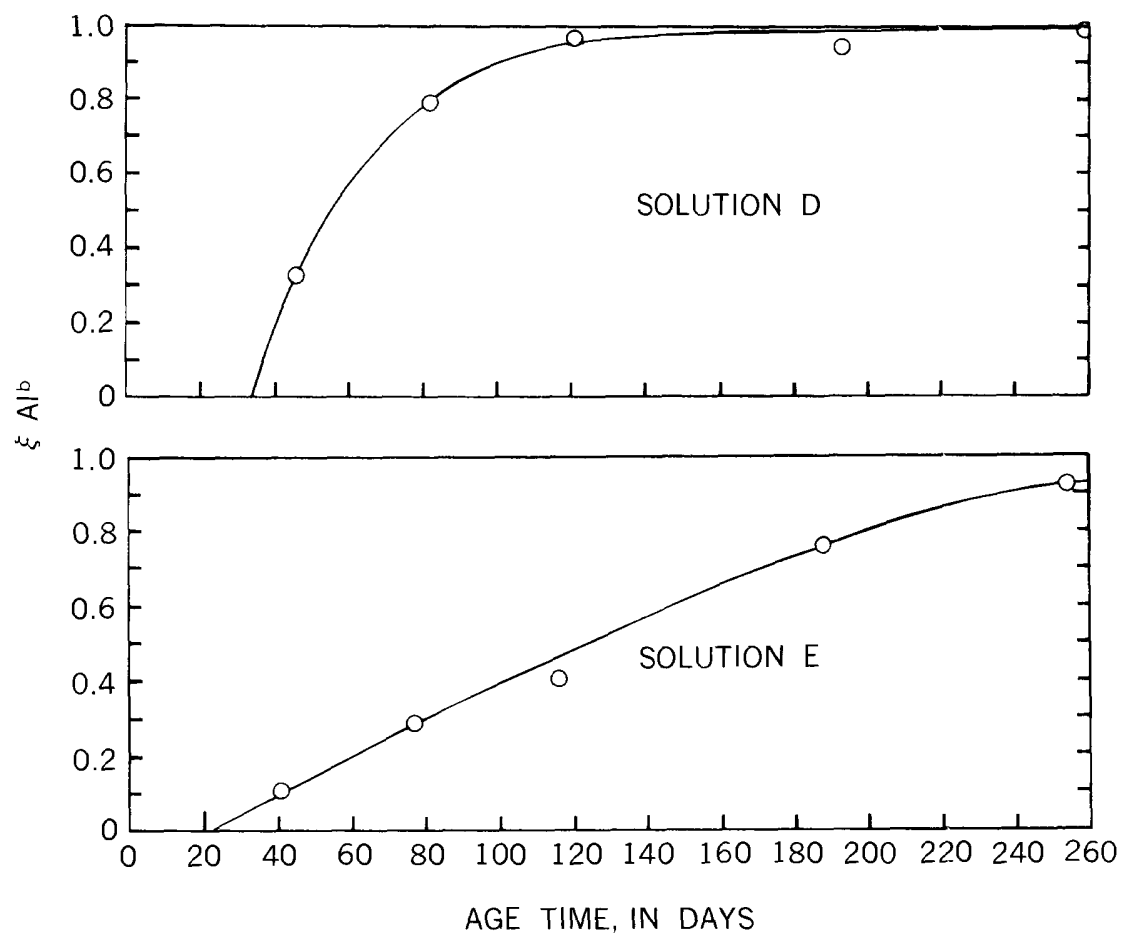

FIGURE 29.-Advancement of the reaction $\left(\xi_{\mathrm{Al}}\right)$ as a 
Only at the start, when there is little loss of $\mathrm{Al}^{\mathrm{b}}$ from the solution and later as equilibrium is closely approached, does the reaction deviate significantly from first order. At short aging times there is a $\mathrm{pH}$ drop indicating some considerable combination of $\mathrm{Al}^{\mathrm{b}}$ particles. However, these particles do not become sufficiently large and do not change character sufficiently at this stage to be considered $\mathrm{Al}^{c}$ particles. Near the finish of the approach to equilibrium, perhaps the mass-action law influences the rate of reaction because of the very few $\mathrm{Al}^{\mathrm{b}}$ particles left and the problems related to bringing these few rarticles
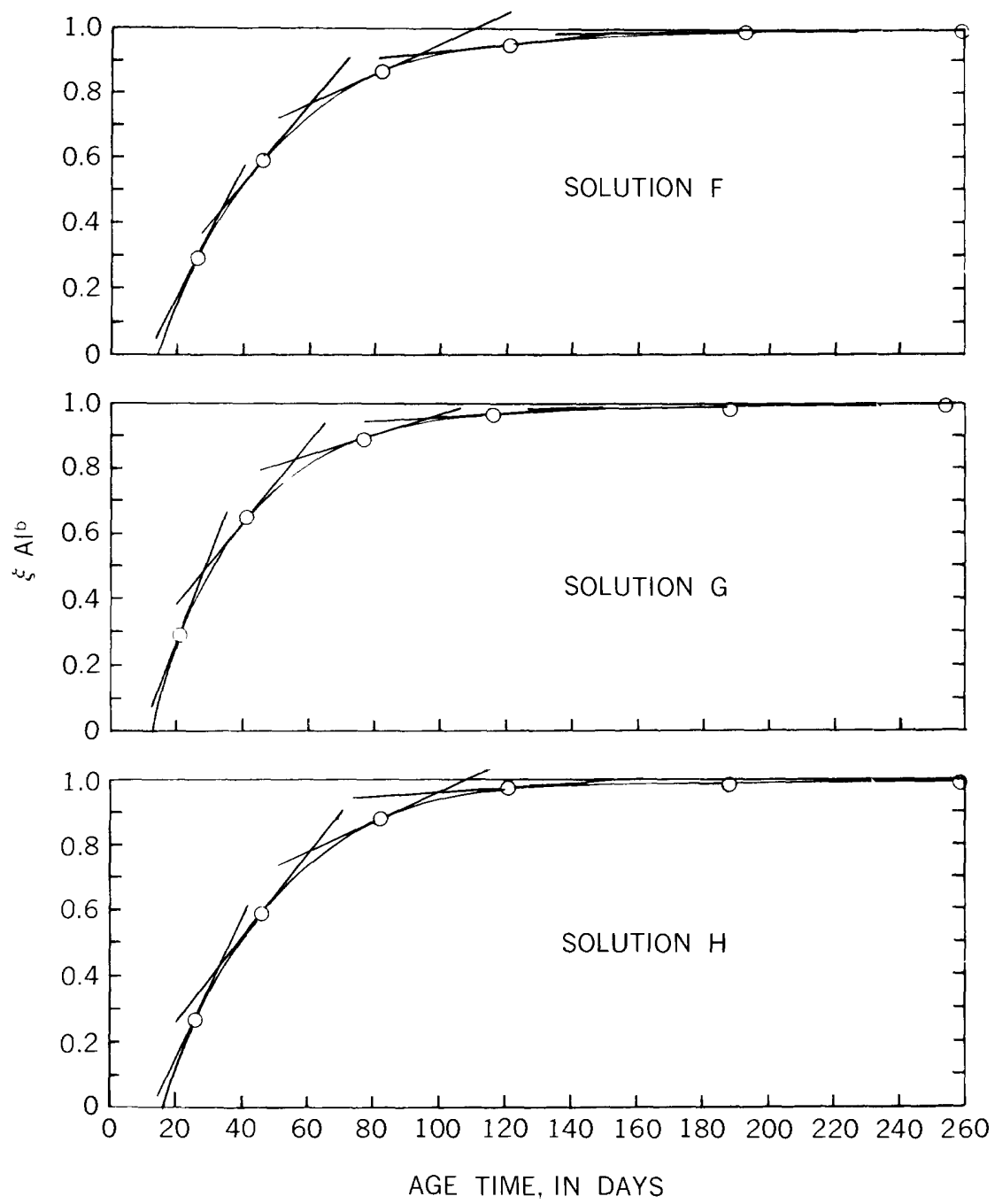

function of aging time for solutions D, E, F, G and $H$. 
TABLE 7.-Estimated order of aging reaction relative to $\mathrm{Al}^{\mathrm{b}}$

\begin{tabular}{ccc}
\hline Solution & $\begin{array}{c}\text { Age time interval } \\
(\text { days })\end{array}$ & $\begin{array}{c}\text { Order of reaction } \\
(n)\end{array}$ \\
\hline & $46-82$ & 0.8 \\
& $82-121$ & 1.0 \\
& $121-193$ & $(1)$ \\
& $26-46$ & .9 \\
& $46-82$ & .9 \\
& $82-121$ & 1.5 \\
& $121-193$ & 3.2 \\
& $21-41$ & 1.0 \\
& $41-77$ & 1.2 \\
& $77-121$ & 1.5 \\
& $121-188$ & 1.4 \\
& $26-46$ & .9 \\
& $46-82$ & .8 \\
& $82-121$ & 1.2 \\
\hline
\end{tabular}

1 Negative value.

together. Figure 30, which shows affinity for the overall thermodynamic reaction versus $d \xi / d t$, tends to confirm this idea. As eruilibrium is approached closely, affinity appears roughly proportional to $d \xi / d t$ in accord with the form of the Marcelin-de Donder equation suitable for use near equilibrium; that is,

$$
V=V_{e} \frac{A}{R T},
$$

where $V$ is the reaction velocity or $d \xi / d t, V_{e}$ is the reaction velocity in the forward direction at equilibrium, $A$ is affinity, $R$ is the gas constant, and $T$ is absolute temperature.

The general first-order rate of disappearance of $\mathrm{Al}^{\mathrm{b}}$ is confirmed by figure 28 , where there is a rough straight-line relationship for several solutions over long aging periods.

\section{CALCULATION OF THE GIBBS FREE ENERGY OF THE "FACE" AND "EDGE" OF GIBBSITE IN EQUILIBRIUM WITH ITS SATURATED SOLUTION}

In the work of Hem and Roberson (1967) a solubility fcr gibbsite material was determined from the results of $\mathrm{Al}^{\text {a }}$ and $\mathrm{pH}$ measurements on samples aged from 1 to about 5 months. The value obtained, a solubility product for $\mathrm{Al}(\mathrm{OH})_{3}$ of $10^{-32.65}$, was denoted by them as applicable to microcrystalline gibbsite - a material having particles from a few hundredths to a few tenths of a micron in diameter. Probably this solubility determination was influenced by $\mathrm{Al}^{\text {b }}$, as this material is not fully precipitated until after longer aging. The difference between $\Delta G^{\circ}$ for the microcrystalline gibbsite of $\mathrm{Hem}$ and Roberson $(-272.3 \mathrm{kcal} / \mathrm{mole})$ and the one given here $(-273.9 \mathrm{kcal} / \mathrm{mole})$ represents, in one way of looking at the data, a particle-size effect. 


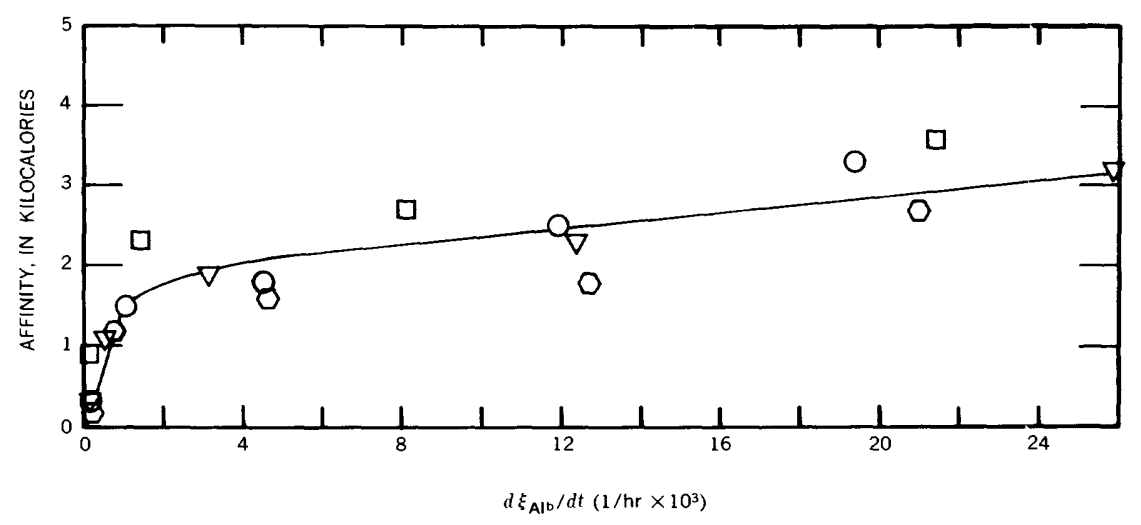

EXPLANATION

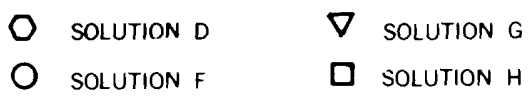

FIGURE 30.-Reaction affinity as a function of reaction velocity $\left(d \xi_{\mathrm{Al}} \mathrm{b} / d t\right)$.

From thermodynamic reasoning (Adamson, 1967) it can be shown, in principle at least, that small crystals should exhibit a greater solubility than large ones. The age study solutions, over much of the aging time, appeared supersaturated with respect to monomeric aluminum species. During the same period, there appeared to be polynuclear aluminum present. If the polynuclear particles are considered to be extremely small crystals, it should be possible from the data ot tained in the course of experimentation to calculate the Gibbs free energy of the (001) crystal face (which will be designated the gibbsite "face") and the (110) and (100) crystal faces (which together will be designated the gibbsite "edge"). These calculations will be made with the gibbsite in equilibrium with its saturated solution. It will also be necessary to estimate the dimensions of the polynuclear particles.

If the $\mathrm{Al}^{\mathrm{b}}$ and $\mathrm{Al}^{\mathrm{c}}$ particles are considered to have the stape of hexagonal platelets of roughly the following form

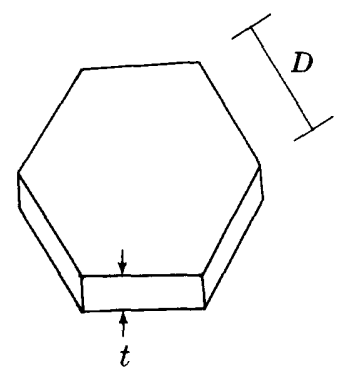


and if surface area $=6 t D+k D^{2}$,

$$
\begin{aligned}
\text { volume } & =V=k D^{2} t, \\
k & =2.598, \\
\rho & =\text { particle density, and } \\
M & =\text { molecular weight of solid, }
\end{aligned}
$$

it should be possible to write a modified expression of the Kelvin equation for solids (Adamson, 1967), relating reaction affinity to interfacial energies. Thus,

$$
A=\frac{2}{3}\left(6 t D_{\gamma_{E}}+2 k D^{2} \gamma_{F}\right) M / V_{\rho},
$$

where $A$ =affinity for the overall reaction $\mathrm{Al}^{+3}+\mathrm{Al}(\mathrm{OH})^{+2}+\mathrm{Al}(\mathrm{OH})_{2}{ }^{+}+\mathrm{Al}(\mathrm{OH})_{4}{ }^{-}+5 \mathrm{H}_{2} \mathrm{O} \rightleftarrows 4 \mathrm{Al}(\mathrm{OH})_{3}+5 \mathrm{H}^{+},(8)$ and where $\gamma_{E}=$ Gibbs energy of the "edge" of a gibbsite particleperchlorate solution interface, and

$\gamma_{F}=$ Gibbs energy of the "face" of a gibbsite particleperchlorate solution interface.

Eliminating $t$ from equation (13),

$$
A=\frac{2}{3}\left(\frac{6 V \gamma_{E}}{k D}+2 k D^{2} \gamma_{F}\right) M / V \rho
$$

Holding $V$ and $\rho$ constant and taking the derivative of $A$ with respect to $\mathrm{D}$,

$$
\frac{d A}{d D}=\frac{2}{3}\left(\frac{-6 V \gamma_{E}}{k D^{2}}+4 k D \gamma_{F}\right) M / V \rho .
$$

To test whether this is a minimum or maximum, take the second derivative

$$
\frac{d^{2} A}{d D^{2}}=\frac{2}{3}\left(\frac{12 V \gamma_{E}}{k D^{3}}+4 k \gamma_{F}\right) M / V_{\rho}>0,
$$

and thus the extremum is a minimum. Setting the first derivative equal to zero and putting $t$ back in the equation,

$$
\frac{6 k D^{2} t \gamma_{E}}{k D^{2}}=6 t \gamma_{E}=4 k D \gamma_{F} \text {, }
$$

and thus,

$$
\gamma_{E}=\frac{2 k D \gamma_{F}}{3 t} .
$$


Substituting back into equation 13 and also eliminating $V$,

$$
\gamma_{F}=\frac{t A \rho}{4 M}
$$

Similarly,

$$
\gamma_{E}=\frac{k D A \rho}{6 M}=2.598 \frac{D A \rho}{6 M}
$$

Equation 18 can also be written as

$$
\frac{\gamma_{E}}{\gamma_{F}}=\frac{2 k D}{3 t}
$$

Close observation of the electron micrograph in figure 19 indicates that the ratio $D / t$ has a numerical value of about 2 . If this value is assumed, equation 21 reduces to

$$
\frac{\gamma_{E}}{\gamma_{F}}=3.46
$$

Equations 19-22 can now be used to estimate $\gamma_{E}$ and $\gamma_{F}$. Affinity for a particular solution at a particular aging time can be readily obtained from the aging study. The density of gibbsite can bo used for $\rho$. The problem, then, in solving these equations revolves about estimating $D$.

According to Hem and Roberson (1967), the probable way in which six or more aluminum hydroxide-water octahedra are bound together is through sharing of two adjacent hydroxide ions. Six-membered rings of the form shown in figure 26 can be produced owing to the angles at which the octahedra are joined. The maximum dimension of such a ring is about $9 \mathrm{~A}$, and a single ring probably has the formula $\mathrm{Al}_{6}(\mathrm{OH})_{12}\left(\mathrm{H}_{2} \mathrm{O}\right)_{12}{ }^{+6}$ (Hem and Roberson, 1967; Hsu and Bates, 1964b) if all hydroxide is assumed to be present in bridging, or shared positions. This type of structure should grow by coalescence of such rings which would accompany deprotonation of water in the shared positions. Hsu and Bates (1964b) proposed a coalesced-ring structural pattern of the types shown in figure 27 for such enlarged structures. The $\mathrm{OH}: \mathrm{Al}$ ratio of the single-ring structure is 2.0 , and as the rings coalesce into larger structures, the $\mathrm{OH}: \mathrm{Al}$ ratio becomes large, approaching a maximum of 3.0 for very large structures. Figure 25 shows the relationship between the number of $\mathrm{Al}^{+3}$ ions per structural unit and $\mathrm{OH}: \mathrm{Al}$ ratio. Considering that the maximum dimen- 
sion across a ring is $9 \mathrm{~A}$, the following simplified figure can be constructed:

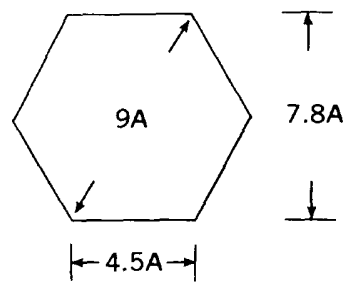

Using Hsu and Bates' coalescence structure, it can be seen that, if there are six aluminum atoms per structure, the $D$ dimension is about $4.5 \mathrm{~A}$; if there are 24 , the dimension $D$ is about $15.6 \mathrm{~A}$; if there are 54 , the dimension $D$ is about $23.4 \mathrm{~A}$; and so forth. From this information, figure 31 was constructed. If, then, the $\mathrm{OH}: \mathrm{Al}$ ratio of the small

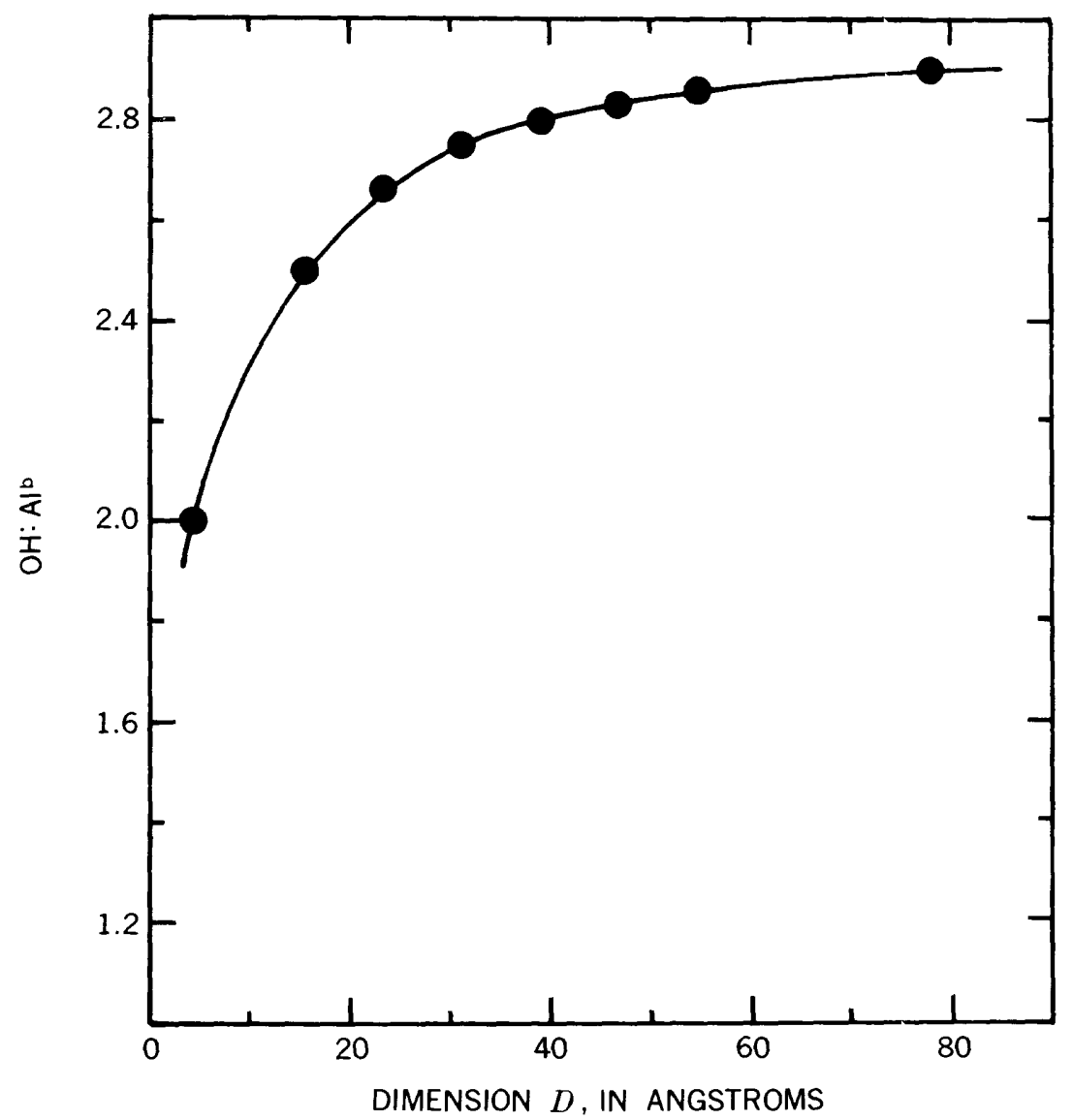

FIgURE 31.-Relationship between the $D$ dimension of the $\mathrm{Al}^{\mathrm{b}}$ particles and the $\mathrm{OH}: \mathrm{Al}^{\mathrm{b}}$ ratio of these particles. 
TABLE 8. - $\mathrm{OH}: \mathrm{Al}^{\mathrm{b}}$ ratios $(r)$ for $\mathrm{Al}^{\mathrm{b}}$ particles and corresponding reaction affinities (A) [For each solution, $A$ values, upper row of figures; $r$ values, lower row. Italic figures indicate values used

\begin{tabular}{|c|c|c|c|c|c|c|c|c|c|c|}
\hline Solution & $\begin{array}{l}23 \\
\mathrm{hr}\end{array}$ & $\begin{array}{c}\text { 48-96 } \\
\mathrm{hr}\end{array}$ & $\begin{array}{c}168 \\
\mathrm{hr}\end{array}$ & $\begin{array}{c}288 \\
\mathrm{hr}\end{array}$ & $\begin{array}{c}505-625 \\
\mathrm{hr}\end{array}$ & $\begin{array}{l}41-46 \\
\text { days }\end{array}$ & $\begin{array}{c}77-82 \\
\text { days }\end{array}$ & $\begin{array}{c}116-121 \\
\text { days }\end{array}$ & $\begin{array}{c}188-193 \\
\text { days }\end{array}$ & $\begin{array}{c}254-259 \\
\text { days }\end{array}$ \\
\hline 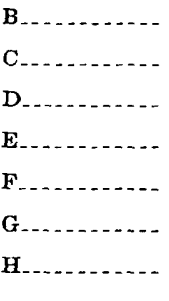 & $\begin{array}{l}6.5 \\
1.8 \\
6.6 \\
2.9 \\
7.4 \\
2.7 \\
8.0 \\
2.5 \\
8.2 \\
2.5 \\
7.6 \\
2.3 \\
8.9 \\
2.1\end{array}$ & $\begin{array}{l}7.3 \\
1.2 \\
6.1 \\
2.9 \\
6.8 \\
2.6 \\
8.1 \\
2.7 \\
6.5 \\
2.6 \\
7.0 \\
2.3 \\
7.2 \\
1.6\end{array}$ & $\begin{array}{l}6.6 \\
1.6 \\
6.2 \\
3.2 \\
6.1 \\
2.5 \\
6.2 \\
2.4 \\
6.1 \\
2.6 \\
5.8 \\
2.2 \\
4.7 \\
2.2\end{array}$ & $\begin{array}{r}-- \\
6 . \overline{5} \\
2.6 \\
6.2 \\
2.6 \\
-- \\
-\overline{-} \\
4.8 \\
2.6 \\
-- \\
4 . \overline{1} \\
2.3\end{array}$ & $\begin{array}{l}6.9 \\
2.2 \\
6.6 \\
2.2 \\
4.8 \\
2.6 \\
6.1 \\
2.5 \\
3.3 \\
2.8 \\
3.2 \\
2.6 \\
2.7 \\
2.4\end{array}$ & $\begin{array}{l}6.5 \\
2.7 \\
6.6 \\
3.2 \\
3.6 \\
2.6 \\
6.0 \\
2.5 \\
2.5 \\
2.2 \\
2.3 \\
2.8 \\
1.8 \\
2.9\end{array}$ & $\begin{array}{l}6.5 \\
2.6 \\
6.9 \\
2.7 \\
2.7 \\
2.3 \\
6.0 \\
2.4 \\
1.8 \\
3.1 \\
1.9 \\
4.8 \\
1.6 \\
3.7\end{array}$ & $\begin{array}{l}6.5 \\
2.1 \\
6.6 \\
2.8 \\
2.8 \\
2.7 \\
5.8 \\
2.5 \\
1.5 \\
3.8 \\
1.1 \\
1.2 \\
-.-\end{array}$ & $\begin{array}{l}6.3 \\
2.2 \\
6.6 \\
2.2 \\
0.9 \\
6.4 \\
4.5 \\
1.4 \\
0.3 \\
0 . \overline{3} \\
0 . \overline{2} \\
. .\end{array}$ & $\begin{array}{l}6.3 \\
2.2 \\
6.6 \\
2.3 \\
0.5 \\
2.0 \\
2.6 \\
0.00 \\
0.0 \\
0 . \overline{2} \\
. .\end{array}$ \\
\hline
\end{tabular}

particles present that give rise to supersaturation can be determined, it should be possible to estimate the average size of these perticles. Assuming that the material that causes supersaturation is the $\mathrm{Al}^{\mathrm{b}}$ material determined in the analyses, it should be possible to estimate the $\mathrm{OH}: \mathrm{Al}$ ratios in the various solutions at all aging times by making hydroxide balances. These balances involved assigning the proper amounts of hydroxide to monomeric species and to the $\mathrm{Al}^{\mathrm{c}}$ present, assuming the $\mathrm{Al}^{\mathrm{c}}$ to be $\mathrm{Al}(\mathrm{OH})_{3}$. The $\mathrm{OH}$ that could not be accounted for otherwise was then assigned to $\mathrm{Al}^{\mathrm{b}}$. The $\mathrm{OH}: \mathrm{Al}$ values obtained are obviously different from the ones calculated based on $\mathrm{pH}$ drop. They are for a particular solution at a particular agirg time, and the size of the $\mathrm{Al}^{\mathrm{b}}$ units calculated from these ratios should be average size $\mathrm{Al}^{\mathrm{b}}$ structures for these particular solutions and aging times. The $\mathrm{Al}^{\mathrm{b}}$ structures calculated by the $\mathrm{pH}$ drop method should be for the maximum size $\mathrm{Al}^{\mathrm{b}}$ units formed. For use with the modified particle-size equation, it is obvious that the $\mathrm{Al}^{\mathrm{b}}$ size as calculated for a particular aging time and solution must be used with the affinity value for the same solution and aging time. Table 8 lists the $\mathrm{OH}: \mathrm{Al}^{\mathrm{b}}$ values obtained. Also shown in the table for convenience are appropriate affinity values. For calculation of $\gamma_{E}$ and $\gamma_{F}$ only part of the data was used. Aging times of 96 hours or less (168 hr for solutions $\mathrm{B}$ and $\mathrm{C}$ ) were not considered because it was felt that for such short aging time the solutions possessed greater instability than for longer aging times and could well give poorer values of $\gamma_{F}$ and $\gamma_{E}$. Data at the other extreme (large initial $r$ value and very long aging times) were rejected since so little $\mathrm{Al}^{\mathrm{b}}$ was present that relatively small errors in the hydroxide balance would give rise to large errors in the value of the $\mathrm{OH}: \mathrm{Al}^{\mathrm{b}}$ ratio. Solution $\mathrm{C}$, aged 46 days, was not used because using it would have resulted in an impossible answer.

From equations 19-22 and from data of table 8, the values of $\gamma_{E}$ and $\gamma_{F}$ listed in table 9 were obtained. The 90 -percent confidence 
TABLE 9.-Calculated $\gamma_{\mathbf{E}}$ and $\gamma_{\mathrm{F}}$ values, in ergs per square centimeter

\begin{tabular}{|c|c|c|c|c|c|}
\hline Age & $\gamma_{E}$ & $\gamma_{F}$ & Age & $\gamma_{E}$ & $\gamma_{F}$ \\
\hline \multicolumn{3}{|c|}{ Solution B } & \multicolumn{3}{|c|}{ Solution E } \\
\hline $505 \mathrm{hr} \ldots \ldots$ & 280 & 82 & $168 \mathrm{hr}_{\ldots} \ldots \ldots \ldots$ & 420 & 121 \\
\hline 41 days $\ldots$ & 940 & 273 & $505 \mathrm{hr} \ldots$ & 540 & 156 \\
\hline 77 days. & 740 & 213 & 41 days. & 520 & 151 \\
\hline 116 days & 210 & 60 & $7 \overline{\text { days }}$. & 400 & 117 \\
\hline 188 days. - & 270 & 78 & 116 days & 510 & 147 \\
\hline 254 days . . - & 270 & 78 & \multicolumn{3}{|c|}{ Solution F } \\
\hline \multicolumn{3}{|c|}{ Solution $\mathbf{C}$} & $168 \mathrm{hr} \ldots$ & 690 & 200 \\
\hline $288 \mathrm{hr}_{\ldots} \ldots$ & 740 & 213 & $288 \mathrm{hr}$ & 540 & 156 \\
\hline $625 \mathrm{hr} \ldots$ & 280 & 82 & $625 \mathrm{hr}$ & 720 & 208 \\
\hline 82 days $\ldots . . . . .$. & 1010 & 291 & 46 days & 100 & 30 \\
\hline 121 days ${ }_{-}$- & $\begin{array}{r}1470 \\
280\end{array}$ & $\begin{array}{r}425 \\
82\end{array}$ & \multicolumn{3}{|c|}{ Solution $\mathbf{G}$} \\
\hline 259 days.. & 360 & 104 & $\overline{168} \mathrm{hr}_{\ldots} \ldots \ldots \ldots$ & 240 & 69 \\
\hline \multicolumn{3}{|c|}{ Solution D } & $505 \mathrm{hr}^{4} \ldots \ldots$ & $\begin{array}{l}360 \\
510\end{array}$ & $\begin{array}{l}104 \\
147\end{array}$ \\
\hline$\overline{168 \mathrm{hr} \ldots \ldots . . .}$ & 540 & 156 & & & \\
\hline $288 \mathrm{hr} \ldots \ldots$ & 700 & 204 & \multicolumn{3}{|c|}{ Solution $\mathbf{H}$} \\
\hline $625 \mathrm{hr}$ & 540 & 156 & $168 \mathrm{hr}_{\ldots} \ldots \ldots$ & 200 & 57 \\
\hline 46 days $\ldots$ & 400 & 117 & $288 \mathrm{hr}$ & 180 & 52 \\
\hline 82 days & 150 & 44 & $625 \mathrm{hr}$ & 180 & 52 \\
\hline 121 days . . . . . & 330 & 96 & 46 days $\ldots \ldots$ & 800 & 230 \\
\hline
\end{tabular}

interval of the mean of $\gamma_{E}$, using the $t$ distribution, is $483 \pm 84 \mathrm{ergs} / \mathrm{cm}^{2}$ (ergs per square centimeter). The similar confidence interval of the mean of $\gamma_{F}$ is $140 \pm 24 \mathrm{ergs} / \mathrm{cm}^{2}$. It is of interest to compare these values with other Gibbs energy values of crystals in equilihrium with their saturated solutions as measured by solubility versus particlesize studies. Enüstun and Türkevich (1960) reported the value of 85 $\mathrm{ergs} / \mathrm{cm}^{2}$ for $\mathrm{SrSO}_{4}-\mathrm{H}_{2} \mathrm{O}$ system. Schindler (1967) reports $770 \pm 330$ $\mathrm{ergs} / \mathrm{cm}^{2}$ for $\mathrm{ZnO}-0.2 \mathrm{M} \mathrm{NaClO}$ s solution, $690 \pm 150$ for $\mathrm{CuO}-0.2 \mathrm{M}$ $\mathrm{NaClO}_{4}$ solution, and $410 \pm 130$ for $\mathrm{Cu}(\mathrm{OH})_{2}-0.2 \mathrm{NaClO}_{4}$ solution. The last value is of particular interest considering a hydroxide is being measured and the closeness to our value for the gibl -ite edgeperchlorate solution system.

Several comments should be made regarding $\gamma_{F}$ and $\gamma_{E}$. Frobably in addition to edge and face energies a "corner" energy should be taken into account. Considering figures 26 and 27 it will be ncticed that all "edge" sites cannot be the same. One could, perhaps, trink of the single six-membered ring as consisting only of "faces" and "corners." Such "corners," of course, must have dimensions of area. When two rings become bound together, an "edge" also is introduced. As the structure becomes larger, this "edge" area becomes relatively greater compared to "corner" area. Many of the electron micrographs showing negative gold particles adsorbed on gibbsite edges, imp?rfections, and, in particular, corners tend to confirm the importance of corner adsorption sites and the greater energies associated with these locations. 


\section{CONCLUSIONS RELATIVE TO ALUMINUM IN MILDLY ACID AQUEOUS MEDIA}

From the aluminum hydrolysis work and electron microscopy, several conclusions can be reached relative to the behavior of aluminum in acid aqueous systems. These conclusions are:

1. If aluminum perchlorate solutions are made up to contain $4.54 \times 10^{-4}$ moles/liter aluminum (total ionic strength about $10^{-2}$ molar), provided the nominal ratio of bound hydroxide to aluminum ( $r_{n}$ value) is 3.00 or less, there will initially be present in the system three different forms of aluminum which can be designated $\mathrm{Al}^{\mathrm{a}}, \mathrm{Al}^{\mathrm{b}}$, and $\mathrm{Al}^{c}$. Form $\mathrm{Al}^{\mathrm{a}}$ appears to be composed entirely of the monomeric species $\mathrm{Al}^{+3}, \mathrm{AlOH}^{+2}, \mathrm{Al}(\mathrm{OH})_{2}{ }^{+}$, and $\mathrm{Al}(\mathrm{OH})_{4}{ }^{-}$. Form $\mathrm{Al}^{\mathrm{b}}$ appears to consist of polynuclear aluminum hydroxide species probably of a general six-membered ring structure in which each aluminum is bonded to its neighbor through shared pairs of $\mathrm{OH}$ ions. The individual rings tend to coalesce into larger structures until they ultimately become large enough to be filtered out and identified by electron microscopy as gibbsite crystals. The manner in which the rings coalesce appears to be governed by a first-order rate law relative to the $\mathrm{Al}^{\mathrm{b}}$ material. The $\mathrm{Al}^{\mathrm{b}}$ particles appear to range in size up to $\mathrm{Al}_{100}(\mathrm{OH})_{273}{ }^{+27}$ to $\mathrm{Al}_{400}(\mathrm{OH})_{1150}+50$. Form $\mathrm{Al}$ is solid material which may be initially all or partly amorphous, but which rapidly becomes crystalline and takes on the structure of gibbsite.

2. For a particular $r_{n}$ value the amount of $\mathrm{Al}^{\mathrm{a}}$ is nearly constant, at least after 23 hours' aging, and is independent of how long the solution has aged and the rate at which base was added to the solution in the initial solution preparation. A corollary to this statement is that the amount of $\mathrm{Al}^{\mathrm{b}+\mathrm{c}}$ also is constant. The significance of these statements is great for they indicate that the Gibbs free energy of formation of $\mathrm{Al}^{\mathrm{b}}$ is not much less than solid $\mathrm{Al}^{c}$. In fact, from the affinity calculations the difference appears to be only a few kilocalories. Although the concentration of $\mathrm{Al}^{\text {a }}$ remains constant with aging time the activities of the individual monomeric species adjust themselves almost instantly to change in $\mathrm{pH}$ of the solution.

3. The $\mathrm{pH}$ of the solutions decrease with aging time until equilibrium $\mathrm{pH}$ values are ultimately achieved. The equilibrium $\mathrm{pH}$ values are consistent with known thermodynamic values for monomeric species and solubility products. The equilibrium $\mathrm{pH}$ achieved in a particular solution depends on its initial $r_{n}$ value. The lower the $r_{n}$ value the lower is the equilibrium $r H$. The rate at which equilibrium is approached depends on $r_{n}$ value and also on the rate at which base is added during solution make 
up. The lower the $r_{n}$ value the slower is the progess toward equilibrium. For example, if $r_{n}$ is around 2.8 equilibrium may be achieved in 6 or 8 months (depending on how much $\mathrm{Al}^{\mathrm{b}}$ was initially formed during base addition). If $r_{n}$ value is 1.0 or less, equilibrium will probably not be achieved after serreral years' aging.

4. The amount of $\mathrm{Al}^{\mathrm{b}}$ present in solution after 23 hours' aging de-

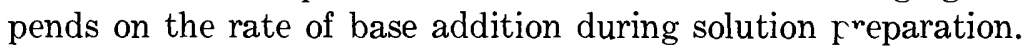
The slower the base is added, the greater the quantity of $\mathrm{Al}^{\mathrm{a}+\mathrm{b}}$ formed and the less $\mathrm{Al}^{\mathrm{c}}$ initially formed. Some of the $\mathrm{Al}^{\mathrm{a}}$ formed is rapidly converted into $\mathrm{Al}^{\text {b }}$, but this conversion is limited by the particle-size solubility effect. Thus, as soon as enough $\mathrm{Al}^{\mathrm{b}}$ is formed to bring this effect into operation, the concentration of $\mathrm{Al}^{\mathrm{a}}$ remains constant. The amount of $\mathrm{Al}^{\mathrm{b}}$ present then decreases as a function of aging time. Over considerable time intervals during aging, the disappearance of $\mathrm{Al}^{\mathrm{b}}$ is approxirnately first order with respect to concentration of $\mathrm{Al}^{\mathrm{b}}$. $\mathrm{As} \mathrm{Al}^{\mathrm{b}}$ disappears from the system, an equivalent amount of $\mathrm{Al}^{c}$ is formed. It seems that $\mathrm{Al}^{\mathrm{b}}$ particles are coalescing into larger particles as a function of time. At some critical size the character of the $\mathrm{Al}^{b}$ particles appears to change, and they behave as the less reactive $\mathrm{Al}^{\mathrm{c}}$ particles. After equilibrium is achieved, the quartity of $\mathrm{Al}^{\mathrm{b}}$ present is below the detection limit.

5. If $\mathrm{Al}^{\mathrm{b}}$ is considered to be small solid particles holding the solution at apparent supersaturation relative to activities of monomeric species, it is possible to estimate the Gibbs free energy of the "face" $\left(\gamma_{F}\right)$ and "edge" $\left(\gamma_{E}\right)$ of a gibbsite particle-perchlorate interface. From the present work, assuming the overall reactions taking place to be

$\mathrm{Al}^{+3}+\mathrm{Al}(\mathrm{OH})^{+2}+\mathrm{Al}(\mathrm{OH})_{2}{ }^{+}+\mathrm{Al}(\mathrm{OH})_{4}{ }^{-}+5 \mathrm{H}_{2} \mathrm{O} \rightleftarrows 4 \mathrm{Al}(\mathrm{OH})_{3}+5 \mathrm{H}^{+}$,

the values (90-percent-confidence-level intervals for the mean of values obtained) for these excess energies are

$$
\begin{aligned}
& \gamma_{E}=483 \pm 84 \mathrm{ergs} / \mathrm{cm}^{2}, \text { and } \\
& \gamma_{F}=140 \pm 24 \mathrm{ergs} / \mathrm{cm}^{2} .
\end{aligned}
$$

\section{REFERENCES}

Adamson, A. W., 1967, Physical chemistry of surfaces: New York, Interscience Publishers, $747 \mathrm{p}$.

Butler, J. N., 1964, Ionic equilibrium-A mathematical approach: Reading, Massachusetts, Addison-Wesley Publishing Co., $547 \mathrm{p}$.

Enüstun, B. V. and Türkevich, John, 1960, Solubility of fine particles of strontium nitrate: Am. Chem. Soc. Jour., v. 82, p. 4502-4509. 
Hem, J. D., 1968, Graphical methods for studies of aqueous aluminum hyc'roxide, fluoride and sulfate complexes: U.S. Geol. Survey Water-Supply Paper 1827-B, p. $3-5$.

Hem, J. D., and Roberson, C. E., 1967, Form and stability of aluminum hydroxide complexes in dilute solution: U.S. Geol. Survey Water-Supply Paper 1827-A, $55 \mathrm{p}$.

Hsu, P. H., and Bates, T. F., 1964a, Fixation of hydroxy-aluminum polymers by vermiculite: Soil Sci. Soc. America Proc., v. 28, p. 763-769.

$1964 \mathrm{~b}$, Formation of X-ray amorphous and crystalline aluminum hydroxides: Mineralog. Mag., v. 33, p. 749-768.

Latimer, W. M., 1952, Oxidation Potentials: New York, Prentice-Hall Inc., 392 p.

Morgan, J. J., 1967, Applications and limitations of chemical thermodynamies in natural water systems, in Equilibrium concepts in natural water systems: Am. Chem. Soc. Advances in Chemistry Series 67, p. 1-29.

Raupach, M., 1963a, Solubility of simple aluminum compounds expected in soils, II. Hydrolysis and conductance of $\mathrm{Al}^{3+}$ : Australian Jour. Soil Research, v. 1, p. $36-45$.

- 1963b, Solubility of simple aluminum compounds expected in scils, IV. Reactions of aluminum hydroxide under acid conditions: Australian Jcur. Soil Research, v. 1, p. 55-62.

Rysselberghe, Pierre van, 1963, Thermodynamics of irreversible processes: New York, Blaisdell Publishing Co., 165 p.

Schindler, P. W., 1967, Heterogenous equilibria involving oxides, hydroxides, carbonates, and hydroxide carbonates, in Equilibrium concepts in natural water systems: Am. Chem. Soc. Advances in Chemistry Series 67, p. 196-221.

Schoen, Robert, and Roberson, C. E., 1970, Structures of aluminum hydroride and geochemical implications; Am. Mineralogist, v. 55, p. 43-77.

Smith, R. W., 1969, The state of $\mathrm{Al}$ (III) in aqueous solution and adsorytion of hydrolysis products on $\alpha \mathrm{Al}_{2} \mathrm{O}_{3}$ : Palo Alto, Calif., Stanford Univ., Ph. D. dissert., $194 \mathrm{p}$.

1971, Relations among equilibrium and non-equilibrium aqueous species of aluminum hydroxy complexes: Am. Chem. Soc. Advances in Chemistry Series 106, p. 250-279.

Thiessen, P. A., 1942, Wechselseitige Adsorption von kolloiden: Ztschr. Elecktrochem. Bd. 48, Nr 12, p. 675-680.

1947, Kennzeichnung submikroskopischer grensflachenbereiche Verschiedenartiger Wirksamkeit: Z. Anorg. Chemie, Bd. 253, p. 161-169.

Turner, R. C., 1969, Three forms of aluminum in aqueous systems determined by 8-quinolinolate extraction methods: Canadian Jour. Chemistry, v. 47, p. 25212527. 